\title{
Saúde e apoio social no trabalho: estudo de caso de professores da educação básica pública
}

\author{
Rodrigo Manoel Giovanetti
}

\begin{abstract}
Dissertação apresentada ao Programa de Pós-graduação em Saúde Pública da Faculdade de Saúde Pública da Universidade de São Paulo para a obtenção do título de Mestre em Saúde Pública.

Área de Concentração: Saúde Ambiental.

Orientadora: Profa. Dra. Ana Isabel Bruzzi Bezerra Paraguay
\end{abstract}

São Paulo

2006 


\section{Agradecimentos:}

Meus agradecimentos à orientadora Dra. Ana Isabel B. B. Paraguay.

À Dra. Mary Jane P. Spink, pelo apoio informativo, material e de avaliação sobre o projeto de pesquisa.

Ao Dr. Rubens Adorno, pelo apoio emocional, informativo e de avaliação sobre o projeto e sobre a dissertação.

À Dra. Marli E. D. A. de André, pelo apoio emocional, informativo, material e de avaliação sobre a dissertação.

Ao Dr. Paulo Afrânio Sant'Anna, pelo apoio emocional e material na proposta do curso.

Aos meus colegas de orientação, pelo apoio emocional, informativo, material e de avaliação sobre o projeto e dissertação.

À Organização Internacional do Trabalho (Brasília/ BRA) e ao National Institute of Industrial Health (Kawasaki/ JAP) pelo apoio material.

Às minhas famílias Giovanetti e Manoel, pelo apoio emocional e material.

À Mirtha Giovanetti, Enio e Cristina Stefani com apoio emocional, material e informativo.

À Evelin C. C. Ribeiro, pelo apoio emocional e material. 


\section{RESUMO}

Giovanetti RM. Saúde e apoio social no trabalho: estudo de caso de professores da educação básica pública. São Paulo; 2006. [Dissertação de Mestrado Faculdade de Saúde Pública da Universidade de São Paulo, Brasil].

Objetivos: o apoio social no trabalho (AST) de professores está associado à prevenção de agravos à saúde e à melhoria do ambiente psicossocial de trabalho, sendo a compreensão de sua estrutura, relevante. Procurou-se descrever a estrutura de AST de professores considerando o sentido suportivo atribuído aos seus conteúdos nas relações sociais de trabalho. Métodos: realizou-se um estudo com contribuição da pesquisa qualitativa em uma escola pública de educação básica da cidade de São Paulo. Foram aplicadas a observação participante e entrevista individual em profundidade como técnicas instrumentais. Fez-se análise de conteúdo

e os resultados foram discutidos com base em aproximações teóricas com a representação social, os fatores psicossociais e a organização do trabalho docente (FPS/OT). Resultados e discussões: foram descritos e especificados os tipos (emocional, instrumental, informativo e de apreciação) e fontes (professores, diretoria, pais/responsáveis e alunos) de AST, que se relacionou com práticas cotidianas para a amenização das exigências de OT e da precarização de recursos educacionais. Sugeriu-se o desenvolvimento de grupos de discussão no trabalho.

DESCRITORES: saúde do trabalhador; ambiente de trabalho; condições de trabalho; organização e administração; doenças ocupacionais; impacto psicossocial; prevenção primária; apoio social; estresse; ensino. 


\section{SUMMARY}

Giovanetti RM. Saúde e apoio social no trabalho: estudo de caso de professores da educação básica pública [Health and Social Support at Work: a case study of teachers from elementary public school]. São Paulo; 2006. [Master's Dissertation - Faculdade de Saúde Pública da Universidade de São Paulo, Brasil].

Objectives: social support at teachers' work (SSW) is associated with illness prevention and improvement of psychosocial working conditions. Hence, identyfing teachers' SSW specific structure is important. The objective of this study was to describe teachers' SSW specific structure in terms of its content. Methods: contributions from qualitative case study were used to assess teachers social relations within Sao Paulo's public elementary school. It was applied participant observations and individual unstructured interviews as instrumental techniques. Data were formulated with content analysis and discussed form a theoretical approach with Social Representation Theory, Psychosocial Factors at Work and Work Organization (PSF/WO). Results and discussion: teachers' SSW structure was based on sources (principal, coworkers, student's fathers and student themselves) and types (emotional, instrumental, informational and appraisal). SSW was associated with workers' formulation of daily educational practices and WO, improving precarious working conditions. It was suggested the development of discussion groups at work.

KEY-WORDS: occupational health; working environment; working conditions; organization and administration; occupational diseases; psicossocial impact; primary prevention; social support; stress; teaching. 


\section{ÍNDICE}

$\begin{array}{ll}\text { 1. INTRODUÇÃOO } & 01\end{array}$

1.1 Condições do trabalho contemporâneo e saúde dos trabalhadores $\quad 01$

1.2 Morbimortalidade no trabalho e a transição epidemiológica 11

$\begin{array}{ll}1.3 \text { Ambiente e aspectos psicossociais no trabalho } & 13\end{array}$

2. JUSTIFICATIVA 17

2.1 Apoio social no trabalho 17

2.1.1 Estrutura de AST 20

2.1.1.1 Tipos de apoio $\quad 20$

2.1.1.2 Fontes de apoio $\quad 22$

2.1.1.3 Mecanismos de ação na saúde 25

2.1.1.4 Repercussões na saúde $\quad 26$

2.2 Saúde e trabalho dos professores da educação básica pública 31

2.2.1 Aspectos epidemiológicos $\quad 32$

2.2.2 Organização e condições de trabalho $\quad 33$

2.2.3 Ambiente psicossocial de trabalho e saúde $\quad 37$

2.2.4 AST docente $\quad 39$

2.4 Problematização da pesquisa 41

3. OBJETIVOS 42

3.1 Geral $\quad 42$

3.2 Específicos $\quad 42$

4. MÉTODOS 43

$\begin{array}{ll}\text { 4.1 Método de pesquisa } & 43\end{array}$

4.2 Participantes $\quad 46$

4.3 Instrumentos de coleta de dados $\quad 48$

4.3.1 Observação participante $\quad 49$

4.3.2 Entrevista individual em profundidade $\quad 50$

4.4 Entrevista em grupo para devolução dos dados 52

4.5 Procedimentos de coleta de dados $\quad 52$

4.5.1 Estudo de caso-piloto $\quad 53$

4.5.2 Estudo da escola-caso $\quad 54$

4.6 Aspectos éticos $\quad 55$

4.7 Procedimento de análise dos dados $\quad 56$

4.7.1 Referencial teórico $\quad 56$

4.7.2 Proposta de análise da observação participante $\quad 63$

4.7.3 Proposta de análise da entrevista individual em profundidade $\quad 64$

4.7.4 Triangulação e síntese dos dados 64

5. ESTUDO DE CASO PILOTO 66

6. RESULTADOS

6.1 Categorias descritivas do apoio social no trabalho 69

6.1.1 Tipos de apoio $\quad 69$ 
6.1.1.1 Apoio emocional $\quad 69$

$\begin{array}{ll}\text { 6.1.1.2 Apoio material } & 70\end{array}$

6.1.1.3 Apoio de apreciação $\quad 72$

6.1.1.4 Apoio informativo $\quad 73$

$\begin{array}{ll}\text { 6.1.2 Fontes de apoio } & 75\end{array}$

6.1.2.1 Apoio da diretoria $\quad 75$

$\begin{array}{ll}\text { 6.1.2.2 Apoio entre professores } & 78\end{array}$

$\begin{array}{ll}\text { 6.1.2.3 Apoio dos pais e responsáveis pelos alunos } & 79\end{array}$

6.1.2.4 Apoio dos alunos $\quad 80$

7. DISCUSSÃO

$\begin{array}{ll}7.1 \text { Tipos de apoio } & 81\end{array}$

$\begin{array}{ll}\text { 7.1.1 Apoio emocional } & 81\end{array}$

$\begin{array}{ll}\text { 7.1.2 Apoio instrumental } & 83\end{array}$

7.1.3 Apoio de apreciação $\quad 84$

$\begin{array}{ll}\text { 7.1.4 Apoio informativo } & 86\end{array}$

$\begin{array}{ll}7.2 \text { Fontes de apoio } & 88\end{array}$

7.2.1 Apoio da diretoria $\quad 88$

7.2.2 Apoio entre professores $\quad 92$

7.2.3 Apoio dos pais e responsáveis pelos alunos 94

7.2.4 Apoio dos alunos $\quad 96$

7.3 Aspectos gerais da estrutura do apoio social no trabalho docente 99

8. CONSIDERAÇÕES E RECOMENDAÇÕES 103

9. REFERÊNCIAS

\section{ANEXOS}

Anexo 1 - Termo de consentimento referente à entrevista e observação no local trabalho - para a diretoria

Anexo 2 - Termo de consentimento referente à entrevista e observação no local trabalho - para a diretoria

Anexo 3 - Termo de consentimento referente à entrevista $\mathrm{e}$ observação no local trabalho - para os professores

A-5

$\begin{array}{ll}\text { Anexo } 4 \text { - Guia de entrevista em profundidade } & \text { A-7 }\end{array}$

$\begin{array}{ll}\text { Anexo } 5 \text { - Guia de diário de campo } & \text { A-8 }\end{array}$ 


\section{INTRODUÇÃO:}

\subsection{Condições do trabalho contemporâneo e saúde dos trabalhadores:}

Desde a década de 1980, percebe-se um intenso movimento de integração econômica mundial e da própria sociedade (BANCO MUNDIAL 2003). Resultado da diminuição de custos de transporte, menores barreiras comerciais, processos de comunicação intensificados e acelerados, fluxos de capitais, de conhecimento tecnológico e de pessoas, a "globalização" - termo utilizado para definir tal processo de integração mundial - iniciou-se por volta de 1870 e atingiu seu auge em meados de 1980, perpetuando-se até a atualidade (BANCO MUNDIAL 2003; STIGLITZ 2002).

A globalização "é um processo complexo que afeta muitos aspectos" do cotidiano e do estilo de vida contemporâneos (BANCO MUNDIAL 2003, p.9). Os benefícios disso se estendem desde a redução da "sensação de isolamento" de nações em desenvolvimento, introdução de novas tecnologias, até o desenvolvimento econômico e o crescimento acelerado de nações pobres, proporcionando condições de vida mais favoráveis com o aumento da expectativa de vida, melhorias na saúde e o aumento do padrão de vida (STIGLITZ, 2002). Segundo o BANCO MUNDIAL (2003), por exemplo, o número de miseráveis nos países em desenvolvimento declinou em 120 milhões, entre 1993 a 1998; já a renda total do mundo tem 
aumentado 2,5 \% ao ano, segundo STIGLITZ (2002). Porém, os desafios da globalização não se estendem somente aos seus aspectos favoráveis e benefícios.

A busca de integração econômica e social, com a intenção de reduzir a pobreza, também tem seus malefícios, como, por exemplo, a marginalização dos países mais pobres, políticas monetárias equivocadas, dificuldades com a diversificação e a integração cultural e devastação do meio-ambiente (BANCO MUNDIAL 2003; STIGLITZ 2002).

A globalização está associada ao avanço dos processos de industrialização e à crescente economia de mercado, que marcam uma mudança nas concepções e condições de trabalho na atualidade. Segundo CASTELLS (1993, p.33), o surgimento de uma "nova estrutura social" está associado ao "surgimento de um novo modo de desenvolvimento [...] historicamente moldado pela reestruturação do modo capitalista de produção". Dessa forma, o trabalho está subordinado, historicamente, à lógica do modelo econômico global, em que, segundo ANTUNES (2000, p.19) "os seres sociais tornam-se mediados e combinados entre si dentro de uma totalidade social estruturada, mediante um sistema de produção e intercâmbio estabelecido" pelo capital.

O processo de "reestruturação da produção e do trabalho", segundo ANTUNES (2000), é o reflexo da reorganização sócio-político-econômica mundial proporcionada pela globalização. O autor assinala que a reestruturação produtiva é uma expressão da resposta à crise do modelo capitalista, que culminou com as 
propostas neoliberais da globalização. É um “processo econômico, político e cultural em curso, de grande dinamismo e alta complexidade, [que] acontece em escala planetária e em ritmo intenso", alterando o modelo produtivo, a divisão do trabalho, o mercado de trabalho, o papel dos sindicatos e as negociações coletivas (RIGOTTO 1998, p.10). Caracteriza-se pelas inovações tecnológicas, introdução de produtos e processos produtivos e disseminação de novos métodos da organização, gestão do trabalho e produção, com a finalidade da flexibilização e a integração do processo de produção (ABRAMIDES e CABRAL 2003; ANTUNES 2000; RIGOTTO 1998; COHN e MARSIGLIA 1994; WOOD JR 1992).

WOOD JR (1992) divide, historicamente, o processo de reestruturação produtiva em três diferentes momentos: o taylorismo/fordismo, o toyotismo e o volvismo. $\mathrm{O}$ autor assinala que o taylorismo/fordismo, com início marcado pela revolução industrial e a implantação dos parques industriais na Inglaterra e em toda a Europa, tem por princípios a produção em massa com a rotinização das tarefas, a repetitividade e a divisão rígida das tarefas, o estreitamento do controle no trabalho, a parcelização e fragmentação do trabalho, dentre outras. As conseqüências dos princípios do taylorismo/fordismo são o aumento do absenteísmo e rotatividade e a restrição das habilidades genéricas no trabalho, tornando o trabalho desumano. ANTUNES (2000) ressalta a desqualificação do trabalhador na participação da cadeia produtiva, suprimindo a dimensão intelectual e a perda das destrezas no trabalho operário. 
Com o taylorismo/fordimo, implantou-se "uma sistemática baseada na acumulação intensiva, uma produção em massa executada por operários predominantemente semiqualificados" (ANTUNES 2000, p.37). Esse modelo de organização do trabalho foi responsável pela "expropriação intensificada do operário-massa, destituindo-o de qualquer participação na organização do processo de trabalho, que se resumia a uma atividade repetitiva e desprovida de sentido" (ANTUNES 2000, p.41). Mesmo assim, "parte dos princípios tayloristas-fordistas ainda são válidos em muitas condições específicas de empresas” (WOOD JR 1992, p.11).

No Brasil, como o processo de industrialização foi tardio, por volta dos anos de 1950 e 1960 houve grande aumento das indústrias brasileiras estruturadas nos princípios tayloristas/fordistas e na idéia de "rotinização" para o controle da força de trabalho (SALERNO 2004). Com isso, previa-se pouca ou nenhuma mudança dos processos industriais, total controle social dentro das fábricas, desvalorização do salário e a inibição das lutas sindicais para seu aumento (SALERNO 2004; ANTUNES 2000).

WOOD JR (1992) considera que o toyotismo surgiu como uma resposta ao modelo anterior de organização do trabalho, em que se passou a considerar as correlações de interdependência entre as necessidades humanas e as técnicas na organização. ANTUNES (2000) assinala o descontentamento da classe trabalhadora e os sindicatos, caracterizando uma fase de "ofensiva das lutas dos trabalhadores" por condições de trabalho mais apropriadas, além de, num plano macro, a crise do 
pós II Guerra Mundial, que culminou com a queda dos lucros e a retração do consumo. ANTUNES (2000, p.50) assinala que as "mutações em curso são expressão da reorganização do capital com vistas à retomada do seu patamar de acumulação e ao seu projeto global de dominação".

Com a crise financeira, a necessidade de expansão capitalista, e as lutas operárias por melhores condições de trabalho, o toytismo foi consolidado, fundamentado na flexibilização do trabalho ou produção flexível. Caracteriza-se pela introdução de inovações tecnológicas, a simplificação e o aumento da velocidade do processo de produção. Reduziram-se os custos e implantaram o controle de qualidade dos produtos (Qualidade Total - QT/Círculo de Controle de Qualidade - CCQ), além do estabelecimento de redes de distribuição pautadas na demanda de mercado (JustIn-Time/Kanban) (ANTUNES 2000; WOOD JR 1992).

WOOD JR (1992) assinala que as conseqüências desse modelo foram pressões sofridas pelos trabalhadores para a redução de custos, a necessidade de uma “devoção" à organização e o trabalho com uma margem de lucros insuficientes. ANTUNES (2000) sugere que o toyotismo é responsável pela intensificação da exploração dos trabalhadores porque o trabalho é realizado em diversas máquinas simultâneas, aumento do ritmo da cadeia produtiva e a apropriação das atividades intelectuais para o manuseio das maquinarias automatizadas e informatizadas. Além disso, DURAND (2003) analisa que o sistema toyotista modifica o discurso sobre trabalho mais que a organização do mesmo, oferecendo uma suposta "autonomia de trabalho", para com isso resultar na melhor aceitação do modelo e, ao mesmo tempo, 
na incrementação do ritmo, reduzindo a "porosidade do tempo de trabalho". Os efeitos são, segundo o autor, a mobilização de todos os empregados para a necessidade de se manter o "fluxo tensionado" de produção, "naturalizando" as prescrições, os procedimentos, as pressões do tempo e as urgências.

No Brasil, foi por volta de década de 1980 que se iniciou a implantação do modelo toyotista, que teve como conseqüência direta a intensificação do trabalho e o "aprofundamento da lógica clássica", baseada nos princípios tayloristas/fordistas (SALERNO 2004).

SALERNO (2004) assinala que o volvismo foi uma alternativa ao modelo clássico de organização do trabalho e à alienação do trabalho. WOOD JR (1992) assinala o desenvolvimento do volvismo como uma necessidade de se combinar a flexibilização toyotista com alto grau de automação e informatização para reduzir custos, aumentar a qualidade e a produtividade associada às necessidades humanas no trabalho. $\mathrm{O}$ enriquecimento de cargos e os projetos de ergonomia são alguns dos pontos específicos desse modelo, que favorece a criatividade e a autonomia para o processo de produção. $\mathrm{O}$ autor ainda ressalta a total compatibilidade entre o volvismo e as necessidades do trabalhador.

Já a consolidação das práticas de organização do trabalho baseadas no volvismo ocorreu por volta da década de 1990, não com a finalidade de melhora das condições de trabalho, mas para o aumento da eficiência produtiva (SALERNO 2004). SALERNO (2004) ainda assinala o aumento da precarização do trabalho em 
razão da terceirização das atividades industriais, subcontratações e a flexibilização dos contratos de trabalho, conseqüências do volvismo.

ABRAMIDES e CABRAL (2003), SALERNO (2004) e ANTUNES (2000) consideram que os modelos de flexibilização do processo produtivo se relacionam com maior exploração e controle da força de trabalho, sendo que os avanços tecnológicos visam ao aumento de produtividade, eficiência e qualidade, exigindo um operariado tipo "polivalente". ANTUNES (2000, p.48) afirma que as novas formas de acumulação flexibilizada "possibilitaram o advento de um trabalhador mais qualificado, participativo, multifuncional, polivalente, dotado de 'maior realização no espaço de trabalho"'. E, como conseqüências para os trabalhadores, ABRAMIDES e CABRAL (2003) assinalam o aumento da competitividade, a redução do poder aquisitivo do trabalhador e a submissão ideológica aos programas de controle de qualidade - que suprimem a sustentação ideológica da classe operária.

A flexibilização do trabalho também se relaciona com uma tendência que, segundo SORJ (2000, p.32), “encoraja os trabalhadores a perceberem a si mesmos como empreendedores e a tratarem seus empregadores como clientes de seu serviço", alterando a experiência do trabalho ao fomentar um crescente individualismo. Nesse sentido, RIGOTTO (1998) assinala que as relações sociais de trabalho estão marcadas pela competitividade, quebra dos laços de solidariedade, maior individualismo e maior solidão. 
Desse modo, os modelos contemporâneos de organização e condições de trabalho são consequiências específicas das necessidades do aumento da produtividade e da flexibilização em função do acúmulo de capital e, apesar de possibilitarem o avanço tecnológico do processo produtivo e de novas técnicas de gestão, também são responsáveis pela precarização das condições de trabalho (ABRAMIDES e CABRAL 2003; MINISTÉRIO DA SAÚDE 2001; ANTUNES 2000; RIGOTTO 1998; COHN e MARSIGLIA 1994;).

A reestruturação produtiva proporcionou a "desregulamentação de direitos sociais e trabalhistas: reduziu o quantitativo do operariado fabril; incrementou a terceirização e a subproletarização; estimulou o trabalho precário e parcial e ampliou o desemprego estrutural" (ABRAMIDES e CABRAL 2003, p.5).

Como consequiências da precarização do trabalho, podem ser observados:

o aumento do número de trabalhadores autônomos e subempregados e a fragilização das organizações sindicais e das ações de resistência coletiva e/ou individual dos sujeitos sociais. A terceirização, no contexto da precarização, tem sido acompanhada de práticas de intensificação do trabalho e/ou aumento da jornada de trabalho, com acúmulo de funções, maior exposição a fatores de riscos para a saúde, descumprimento de regulamentos de proteção à saúde e segurança, rebaixamento dos níveis salariais e aumento da instabilidade no emprego. Tal contexto está associado à exclusão social e à deterioração das condições de saúde (MINISTÉRIO DA SAÚDE 2001, p.19). 
O MINISTÉRIO DA SAÚDE (2001, p.19) sugere que, no país, “as relações entre trabalho e saúde do trabalhador conformam um mosaico, coexistindo múltiplas situações de trabalho caracterizadas por diferentes estágios de incorporação tecnológica, diferentes formas de organização e gestão, relações e formas de contrato de trabalho". Ou seja, o Brasil se encontra em um processo em que os diversos modelos de organização do trabalho e fases do processo de reestruturação produtiva são mesclados heterogeneamente (ABRAMIDES e CABRAL 2003; WOOD JR 1992).

EL-BATAWI (1987) complementa que os trabalhadores dos países em desenvolvimento precisam adaptar-se a rápidas mudanças resultantes da industrialização tardia e da transição entre a vida rural e as indústrias. Para o autor, esses processos transitórios produzem condições de trabalho estressantes devido ao tipo de trabalho e à própria suscetibilidade individual, resultando em absenteísmo e distúrbios psicológicos e psicossomáticos. Complementar, RIGOTTO (1998, p.15) afirma que a "saúde humana, hoje, é profundamente marcada pela forma como se vive, no Brasil e no mundo, o processo de Globalização e Reestruturação Produtiva”.

O trabalho precário, pois, apresenta repercussões adversas para a saúde dos trabalhadores (ABRAMIDES e CABRAL 2003; PARAGUAY 2003; MINISTÉRIO DA SAÚDE 2001; RIGOTTO 1998; COHN e MARSIGLIA 1994; THEORELL 1991; KALIMO 1987). 
As influências da organização e das condições de trabalho ocorrem por meio de mecanismos desencadeadores e agravadores de patologias direta ou indiretamente relacionadas ao trabalho, repercutindo nos padrões de morbimortalidade da população, o que se torna um fator de preocupação no âmbito da saúde pública (PARAGUAY 2003; HEMSTRÖM 2001; MINISTÉRIO DA SAÚDE 2001; LACAZ 1997; ARNETZ 1996; MENDES e DIAS 1991).

O MINISTÉRIO DA SAÚDE (2001, p.17) relaciona os mecanismos desencadeadores e agravadores de patologia com as condições de vida, com a organização do trabalho e com os riscos ocupacionais:

Entre os determinantes da saúde do trabalhador estão compreendidos os condicionantes sociais, econômicos, tecnológicos e organizacionais responsáveis pelas condições de vida e os fatores de risco ocupacionais - físicos, químicos, biológicos, mecânicos e aqueles decorrentes da organização laboral - presentes nos processos de trabalho. Assim, as ações de saúde do trabalhador têm como foco as mudanças nos processos de trabalho que contemplem as relações saúde-trabalho em toda a sua complexidade, por meio de uma atuação multiprofissional, interdisciplinar e intersetorial.

Segundo o MINISTÉRIO DA SAÚDE (2001), os riscos ocupacionais se referem a elementos presentes no ambiente ocupacional que modificam o curso e a evolução da qualidade de vida e dos agravos à saúde do trabalhador à medida de que aumentam as chances de ocorrência de uma doença ocupacional ou relacionada ao 
trabalho. Esses podem ser classificados, segundo o autor, em cinco grupos: (a) físicos, (b) químicos, (c) biológicos, (d) ergonômicos e psicossociais e (e) mecânicos e de acidentes.

\subsection{Morbimortalidade no trabalho e a transição epidemiológica:}

A importância da identificação dos riscos no trabalho refere-se ao delineamento etiológico dos padrões de morbimortalidade dos trabalhadores para posterior controle. Porém, a etiologia dos padrões de morbimortalidade ocupacionais tem se modificado juntamente com as formas de organização e condições de trabalho (HEMSTRÖM 2001; MINISTÉRIO DA SAÚDE 2001; PETER e SIEGRIST 2000; THEORELL 1997, 1991).

Identificam-se, ao lado dos riscos físicos, químicos, biológicos e mecânicos, as crescentes exigências psicológicas que agravam ou geram o estresse ocupacional e as conseqüentes doenças relacionadas ao trabalho (HEMSTRÖM 2001; MINISTÉRIO DA SAÚDE 2001; PETER e SIEGRIST 2000; THEORELL 1997, 1991). PETER e SIEGRIST (2000, p.41) afirmam que as mudanças no trabalho contemporâneo "induziram a uma mudança das condições adversas de trabalho, de fatores tradicionais, como os riscos físicos e químicos, para trabalhos com demandas psicossociais, mentais e emocionais".

Complementar a essa idéia, o MINISTÉRIO DA SAÚDE (2001) considera que novos e diferentes fatores de riscos contribuem com o aumento da incidência de 
doenças como a lesão por esforços repetitivos - LER/DORT, o estresse ocupacional e a fadiga física e mental. Já COHN e MARSIGLIA (1994, p.73) afirmam que "a redução de esforço físico vem acompanhada, assim, de significativo desgaste psíquico do trabalhador expresso em sintomatologias de fadiga, estresse e demais patologias psicossomáticas e nervosas".

A mudança do perfil de adoecimento do trabalhador se relaciona com a transição epidemiológica dos padrões de morbimortalidade em Saúde Pública, caracterizado pelas taxas elevadas de prevalência e incidência de doenças não infecciosas como, por exemplo, as cardiovasculares, neoplasias, disfunções imunológicas e os transtornos mentais (WALDMAN 2000; ARNETZ 1996; PHILLIPS e VERHASSELT 1994). Esses padrões implicam em novos desafios para a Saúde Pública.

PHILLIPS e VERHASSELT (1994) explicam que existe uma inter-relação complexa entre saúde e as políticas de desenvolvimento globais, tanto em seus aspectos sociais quanto econômicos. Os autores exemplificam a idéia com três grupos de problemas que influem na crise da saúde, delimitados pela Organização Mundial de Saúde: (a) a magnitude e diversidade dos riscos à saúde associados ao desenvolvimento, (b) os custos das doenças causadas pela industrialização e a urbanização e (c) a necessidade ou imposição de um ajuste macroeconômico que resultou em cortes orçamentários nos investimentos nas áreas sociais e da saúde na maioria dos países em desenvolvimento. Os autores ainda assinalam que as influências dos fatores na crise da saúde e a transição epidemiológica ocorrem por 
meio dos impactos das políticas de desenvolvimento na saúde, das mudanças das condições ambientais e da urbanização/modernização dos espaços coletivos.

\subsection{Ambiente e fatores psicossociais no trabalho:}

No processo de mudança do perfil de adoecimento no trabalho, assinala-se o impacto do ambiente e fatores psicossociais de trabalho sobre a saúde (MARMOT 2004; HEMSTRÖM 2001; MINISTÉRIO DA SAÚDE 2001; SIEGRIST e THEORELL 1997, 1991; ARNETZ 1996; EL-BATAWI 1987; KALIMO, 1987).

De modo geral, um ambiente psicossocial se constitui pela interação entre os processos psíquicos e sociais no nível das atitudes, interação das pessoas e grupos no cotidiano e seus sentimentos, sendo qualificado pela reciprocidade e complementaridade das características psíquicas e sociais (MAISONNEUVE 1977). SIEGRIST e MARMOT (2004) assinalam que o ambiente psicossocial corresponde ao encontro entre as oportunidades oferecidas pela estrutura social e as necessidades

psicológicas. É um conceito baseado nas interações dinâmicas entre o individual e o social.

Os fatores psicossociais no trabalho se referem:

às interações entre o ambiente, conteúdo e condições de trabalho com as capacidades do trabalhador, necessidades, cultura, elementos pessoais extratrabalho, que podem, pela percepção e experiência, influenciar a 
saúde, satisfação e desempenho no trabalho (INTERNATIONAL LABOUR OFFICE 1986, p.3).

KALIMO (1987) afirma que os fatores psicossociais no trabalho são relevantes porque repercutem na causa, prevenção de doenças relacionadas e na promoção da saúde no trabalho.

Outros modelos teóricos descrevem as dimensões dos fatores psicossociais no trabalho. Por exemplo, KARASEK e THEORELL (1990) propõem um modelo que vem sendo desenvolvido desde 1979, de três dimensões de demanda-controle-apoio social, em que altas demandas associadas a baixo controle das tarefas e falta de apoio geram reações de tensão e consequiente estresse. Os autores citam os componentes das três dimensões psicossociais: (a) tomada de decisão, (b) demandas psicológicas e carga de trabalho mental, (c) apoio social, (d) demandas físicas e (e) insegurança no trabalho.

Para COX e col. (2000), os fatores psicossociais no trabalho podem ser compostos por: (a) conteúdo do trabalho (ambiente e equipamentos de trabalho, concepções da tarefa, carga e ritmo de trabalho, aspectos temporais) e (b) contexto do trabalho (cultura organizacional e funções, papel na organização, desenvolvimento de carreira, latitude de decisão e controle, interações entre trabalho e lar, relações sociais no trabalho).

PETER e SIEGRIST (2000) assinalam outro modelo, o desequilíbrio entre esforço e recompensa, em que a falta de reciprocidade entre "esforços" e 
"recompensas" no trabalho geram reações de tensão seguidas de estresse ocupacional. Os autores assinalam que as categorias das dimensões do modelo são: (a) segurança no trabalho, (b) desenvolvimento e oportunidades na carreira, (c) salário, (d) estima e (e) estratégias psicológicas de enfrentamento. Para SIEGRIST e MARMOT (2004), esses modelos são complementares entre si e a sobrecarga em um implica num efeito sinérgico direcionado ao outro.

EL-BATAWI (1987) cita que é possível diferenciar os fatores psicossociais por meio das repercussões que esses apresentam na saúde, tomando-se como base duas categorias principais: uma referente aos efeitos dos adversos e a outra referente aos efeitos favoráveis à saúde dos trabalhadores.

A categoria de "risco psicossocial", diferenciada nos grupos de fatores de risco ocupacionais do MINISTÉRIO DA SAÚDE (2001), refere-se aos fatores psicossociais que apresentam repercussões adversas para a saúde do trabalhador. Essas repercussões podem englobar um conjunto de sintomas e patologias relacionadas ao trabalho, como, por exemplo, doenças cardiovasculares, LER/DORT (lesões por esforços repetitivos/distúrbios ósteomusculares relacionados ao trabalho), síndromes depressivas e de ansiedade, alcoolismo, abuso de drogas, distúrbios do sono, síndrome do esgotamento profissional (burnout), disfunções neuroendócrinas e imunológicas (ANDREA e col. 2003; BENEVIDES-PEREIRA 2002; LEVI 2002; MINISTÉRIO DA SAÚDE 2001). 
Já os efeitos favoráveis dos fatores psicossociais se relacionam com a promoção da saúde, a satisfação no trabalho e a prevenção de doenças relacionadas ao trabalho (MARTINEZ e col. 2004; LEVI 2002; THEORELL 1991; EL-BATAWI 1987). KALIMO (1987) assinala que o trabalho pode ser promotor de saúde porque pode proporcionar, por meio dos fatores psicossociais: (a) um senso de pertença a uma parte da sociedade, considerada importante, necessária e valorizada, (b) expressão de aptidões e o ganho, aprimoramento e exercício de habilidades, (c) entrada num ambiente social de interações baseadas em metas e objetivos e apoio mútuo, (d) oportunidade de assumir uma variedade de funções no cotidiano, que aumentam as possibilidades de realização de diferentes aspectos da personalidade, (e) estrutura de trabalho moldada por um tempo específico e (f) recompensa financeira para prover necessidades básicas. 


\section{JUSTIFICATIVA:}

\subsection{Apoio social no trabalho:}

A importância das relações sociais na saúde tem sido destacada por meio de suas associações com mortalidade, morbidade física e psicológica e recuperação em doenças crônicas (COHEN e col. 2000). O apoio social também é um dos fatores psicossociais no trabalho relevantes para a compreensão e o estudo da saúde dos trabalhadores (BETRÁN e col. 2004; KARLIN e col. 2003; KORTUM 2003; LEVI 2002; DOLLARD e col. 2000; SARGENT e TERRY 2000; THEORELL 1991; INTERNATIONAL LABOUR OFFICE 1986; HOUSE 1983).

Historicamente, o apoio social foi um conceito introduzido na área de saúde por Caplan, Cassel e Cobb, na década 1970 (BETRÁN e col. 2004; COHEN e col. 2000; HUPSEY 1998; HOUSE e col. 1988; HOUSE 1983). Tornou-se um conceito associado à teoria cognitivista do estresse como fator relevante nos processos de saúde-doença, mas também apresenta uma tradição relacionada com as teorias de Durkheim sobre integração social e bem-estar psicológico e outra vertente relacionada com os processos interpessoais, valorizando o contexto de ocorrência do apoio (COHEN e col. 2000). O apoio social no trabalho (AST) é uma derivação teórica e conceitual do apoio social global aplicada ao ambiente de trabalho, que foi introduzida por James House e seu grupo de estudos de AST, em 1981 (UNDÉN 1996). 
Pela diversidade de origens teóricas que sustentam o construto, tem-se procurado um consenso em relação à sua definição, estrutura e funções (BETRÁN e col. 2004; COHEN e col. 2000; HUPSEY 1998; THOITS 1995; HOUSE e col. 1988; HOUSE 1983). Autores concebem o apoio social basicamente de forma semelhante, com algumas variações nas definições (HUPSEY 1998), que muitas vezes impossibilitam o uma compreensão operacional do mesmo.

O apoio social dos trabalhadores pode ser classificado como institucional ou interpessoal (INTERNATIONAL LABOUR OFFICE 1986). O tipo institucional tem sido estudado como "apoio organizacional - organizational support" e se refere aos sistemas gerais de percepção do trabalhador sobre a preocupação da empresa quanto às suas contribuições gerais e seu bem-estar (RHOADES e EISENBERGER 2002). Já o tipo interpessoal se remete aos estudos das relações sociais no ambiente de trabalho (INTERNATIONAL LABOUR OFFICE 1986), com a denominação de “apoio social no trabalho - social support at work". Nesta pesquisa, optou-se pelo estudo do apoio social no trabalho.

Quanto à definição, HOUSE (1983, p.26) assinala que AST é um "fluxo de preocupação emocional, ajuda instrumental, e fornecimento de informações para auto-avaliação entre pessoas". HOUSE e col. (1988) especificam-no como uma dimensão de qualidade favorável existente no conteúdo das relações sociais no trabalho. Já THOITS (1995) afirma que o apoio social é uma função de auxílio a indivíduos, desempenhada por pessoas significativas, em termo de provisão social (de materiais, informações e assistência emocional) à qual se pode recorrer quando se 
enfrenta uma situação de estresse. BETRÁN e col. (2004) assinalam que as relações de apoio social se caracterizam pelas trocas e provisão de ajuda entre indivíduos, para satisfazer as necessidades, em uma rede social específica, diferenciando-se do companheirismo e das simples interações sociais por ter o caráter de busca voluntária pela ajuda. HUPSEY (1998, p.313), em uma análise da maturidade teórica do conceito, sugere ser "uma ação bem intencionada que é dada voluntariamente a uma pessoa com a qual se tem uma relação pessoal, e que produz uma resposta positiva imediata ou posterior na pessoa receptora".

Sugere-se uma síntese e reformulação das definições de AST, em termos de uma relação social formal e/ou informal significativa que tende a suprir as necessidades emocionais, instrumentais, informativas e de apreciação sobre o trabalho realizado, com o objetivo de favorecer o trabalhador na adaptação ao ambiente de trabalho para a operacionalização da tarefa prescrita.

SCHAEFER e col. (1981) já sugeriram a dificuldade de definição e conceitualização do construto, o que foi verificada também na diversidade e ausência de acordo comum entre os pesquisadores em estudos recentes (HUPSEY 1998). HOUSE e col. (1988) e assinalaram a necessidade de se melhor compreender a estrutura e o processo pelos quais as relações sociais influenciam a saúde e bemestar, por meio da estrutura do apoio social, enquanto que THOITS (1995) ressaltou a necessidade de sua compreensão estrutural para se construir estratégias interventivas efetivas na saúde. Porém, as divergências conceituais também se encontram nas definições de suas estruturas, necessitando de reformulações 
adequadas aos contextos específicos de ocorrência. HOUSE (1983) já assinalava que, para se compreender o conceito de AST, era necessário estudar "quem fornece o que para quem referente a quais problemas" (p.22).

Para a compreensão da estrutura específica de AST, realizou-se uma revisão bibliográfica nas bases de dados LILACS, MEDLINE, SOCIOLOGICAL ABSTRACT, PSYCINFO, CISDOC, NIOSHTIC, PSYCOLOGICAL ABSTRACT e no sistema de busca GOOGLE SCHOLAR@ (período de 1980 a 2006). Os dados sobre AST foram sistematizados, teoricamente, em quatro conteúdos para análise de sua estrutura: (a) tipos, (b) fontes, (c) mecanismos de ação na saúde e (d) repercussões na saúde dos trabalhadores.

\subsubsection{Estrutura de AST:}

\subsubsection{Tipos de apoio:}

HOUSE (1983) fez uma revisão sobre as definições tipológicas de apoio social e identificou que existem diversas sugestões que não são, necessariamente, excludentes entre si, necessitando assim, de uma reavaliação e reorganização dessas tipologias. Para tanto, o autor sugeriu quatro tipos de AST: (a) apoio emocional (emotional support), (b) apoio de apreciação (appraisal support), (c) apoio informativo (informational support) e (d) apoio instrumental (instrumental support). 
As traduções desses verbetes foram livres para esta pesquisa e basearam-se na proximidade entre os significados originais da língua inglesa (COLLINS 1999), de traduções de inglês-português (COLLINS GEM 1996) e do dicionário da língua portuguesa (FERREIRA 1986). Construiu-se um quadro comparativo com os significados da língua inglesa, tradução do verbete para a língua portuguesa e o significado do verbete traduzido, na língua portuguesa. Concluiu-se que: (a) "emotional" se refere à necessidade emocional e foi traduzido por "emocional", que é relativo à emoção, (b) "instrumental" se refere a instrumentos e foi traduzido por "instrumental", que se refere a um conjunto de instrumentos, (c) "informational" não se encontra nos dicionários COLLINS (1999) e COLLINS GEM (1996), identificando o verbete mais próximo como "informative", que se refere a dar informações úteis, sendo então traduzido por "informativo", que é destinado a informar ou noticiar e (e) "appraisal" se refere à avaliação, estimar valor ou qualidade, e sua tradução foi "apreciação", sinônimo de "avaliação", para se distinguir tal verbete das possíveis significações do termo "avaliação" na área administrativa (que remete à avaliação formal de desempenho) e na educação (que remete à idéia de avaliação cognitiva e de comportamento dos alunos).

As definições dessas quatro categorias são (HOUSE 1983): (a) apoio emocional como a provisão de empatia, cuidado, amor, confiança, afeto, escuta e estima, sendo o tipo de apoio mais freqüentemente percebido pelas pessoas no cotidiano, (b) apoio de apreciação como o fornecimento de informações específicas para a auto-avaliação, (c) apoio informativo como o fornecimento de informações diversas para o enfrentamento das dificuldades e problemas do cotidiano e (d) apoio 
instrumental envolvendo comportamentos instrumentais que auxiliam as pessoas de forma direta em suas necessidades, modificando o ambiente.

Após o estudo de HOUSE (1983) pesquisadores tendem a manter tal tipologia por se mostrar a mais abrangente e melhor definida conceitualmente. Esta pesquisa também adotou tais classificações como categorias prévias para análises dos dados.

\subsubsection{Fontes de apoio:}

As fontes de apoio social para os trabalhadores se referem ao próprio ambiente de trabalho (como o supervisor e os colegas de trabalho) ou extratrabalho (como família, cônjuge, amigos, vizinhos, profissionais da saúde, dentre outros) (BARUCH-FELDMAN e col. 2002; HOUSE 1983).

AST pode se referir somente às fontes no trabalho ou ao trabalho e extratrabalho, nem sempre havendo consenso de pesquisadores na área (JACKSON 1992). HOUSE (1983) afirma que AST se relaciona com a supervisão e os colegas de trabalho somente, sendo as outras possibilidades consideradas extratrabalho (nonwork sources). O autor, ao priorizar as fontes de supervisão e colegas, ressalta a importância do próprio ambiente psicossocial de trabalho e suas influências na saúde como fator principal para estratégias de intervenção. Considera que as fontes extratrabalho são importantes para ajudar no estresse ocupacional, mas apresentam poucos efeitos na saúde e adoecimento no trabalho quando comparadas com as fontes no trabalho. ADAMS e col. (1996) afirmam que as relações entre família e 
trabalho têm importância para a satisfação no trabalho e na vida. Os autores consideram que níveis elevados de apoio emocional e instrumental da família favorecem a baixa interferência no trabalho, enquanto que níveis elevados de interferência do trabalho na família estão associados a níveis baixos de apoio instrumental e emocional.

Diferencia-se o apoio social percebido do fornecido (THOITS 1995). Assinala-se a necessidade de haver integração entre o que é percebido como necessário e o que é fornecido na relação de apoio (THOITS 1995). HOUSE (1983) assinala que as características individuais podem facilitar ou impedir as capacidades de fornecer e receber apoio, além das propriedades das relações sociais e as condições culturais e sociais, que podem promover ou inibir o fornecimento ou percepção de apoio social.

JACKSON (1992) afirma que a diferenciação da eficiência das fontes de apoio social relaciona-se com a "experiência compartilhada", ou seja, a capacidade que a fonte de apoio social tem para compartilhar as experiências do receptor do apoio, em termos de tipos de conteúdo (informações, afetos e instrumentos).

HOUSE (1983) considera que uma fonte de apoio social adequada: (a) tem habilidade e motivação para fornecer apoio e (b) insere-se num contexto relacional e social que facilita e promove os esforços para fornecimento de apoio. Nesse caso, SARASON e col. (1991) afirmam ser relevante a percepção da alteridade no apoio social. 
BOWLING e col. (2004) estudaram reciprocidade e interesse pessoal no trabalho e identificaram que o apoio social está associado às variáveis que compõem a reciprocidade e não associado às variáveis do interesse pessoal, sugerindo que a prontidão da resposta dada às necessidades do trabalhador são potencializadoras dos efeitos de apoio que a atratividade entre trabalhadores. Portanto, a percepção do apoio pelo trabalhador é determinada pela qualidade das trocas interpessoais com pessoas significativas e pouco influenciada pela disposição perceptiva pessoal (VINOKUR e col. 1987), o que sugere a importância do grupo e do coletivo na formação das relações suportivas.

LAROCCO e col. (1980) afirmam que diferentes fontes de apoio promovem efeitos diferentes nas relações sociais e, conseqüentemente, na saúde do trabalhador. Além disso, os autores afirmam que os próprios aspectos organizacionais do trabalho são responsáveis pela determinação da relevância de cada fonte de apoio.

ELFERING e col. (2002) afirmam que a ausência de apoio de supervisão e a presença de apoio de colegas de trabalho "próximos" implicam em sentimentos de dependência, incompetência e obrigações de reciprocidade, que tendem a gerar desgaste no trabalho. Os autores tornam relativa a importância do apoio social de colegas "próximos" por conta da ausência de um ambiente fornecedor de apoio baseado nas estratégias gerenciais. BUUNK e col. (1993) afirmam que trabalhadores tendem a perceber apoio social mais relacionado com os colegas que com supervisão, o que gera ausência de reciprocidade nas relações sociais de trabalho e associa-se a 
afetividade negativa. Já DORMANN e ZAPF (1999) identificaram que o apoio de supervisor funciona como moderador dos efeitos do estresse no trabalho.

\subsubsection{Mecanismos de ação na saúde:}

Os mecanismos de ação de AST na saúde são entendidos por meio de duas hipóteses concorrentes: (a) buffering, que sugere a moderação do impacto do estresse na saúde (e não um efeito direto), modificando a relação entre esses e (b) main effect, na qual o apoio social exerce função direta na promoção de saúde e na eliminação das fontes de estresse, fato que ocorre porque o apoio satisfaz necessidades como segurança, contato social, aprovação, pertença e afeição (KARLIN e col. 2003; CHAY 1993; HOUSE e col. 1988; HOUSE 1983).

Foram identificadas dificuldades nas pesquisas sobre apoio social em decorrência da falta de evidências de primazia tanto da hipótese de buffering quanto de main effect, em estudos de coorte e longitudinais (OLSTAD e col. 2001; UNDÉN 1996; BURKE e GREENGLASS 1995; THOITS 1995; CHAY 1993; CHISHOLM e col. 1986; LAROCCO e col. 1980). A discussão envolve questões sobre os processos e a construção do conceito que tendem a gerar confusões de validação das teorias de apoio social em pesquisas (HUTCHISON 1999; JACKSON 1992; LAROCCO 1982; LARROCO e col. 1980). Tanto o funcionamento causal proposto pelo modelo de main effect, quanto o funcionamento moderador proposto pelo buffering, parecem ser classificações adotadas pelos pesquisadores conforme suas necessidades específicas de pesquisa, não havendo pontos convergentes para o predomínio de uma abordagem 
ou de outra (JACKSON 1992; LAROCCO 1983). Isso se justificaria porque as pesquisas em apoio social enquadram diversos cenários sociais que necessitam de modelos teóricos de compreensão diversificados, o que indica a existência de ambas as hipóteses dependentes das situações nas quais são avaliadas (LAROCCO 1983).

VISWESVARAN e col. (1999) realizaram uma meta-análise de estudos sobre AST e identificaram uma terceira hipótese de mecanismo de ação: a atenuação dos estressores percebidos, ou seja, a redução de aspectos da condição de trabalho percebidos como nocivos à saúde, mas que, para HOUSE (1983), é também característica do modelo de main effect, não contribuindo, então, para o desenvolvimento de uma terceira hipótese da atuação de AST na saúde.

\subsubsection{Repercussões na saúde:}

Apesar das dificuldades metodológicas e conceituais, verificam-se efeitos adversos e agravos à saúde, relacionados com a ausência de AST, bem como suas repercussões favoráveis na prevenção de adoecimento e na promoção da saúde.

Efeitos adversos e agravos à saúde dos trabalhadores relacionados com a ausência ou baixo nível percebido de AST: (a) distúrbios do sono (NORDIN e col, 2005), (b) percepção subjetiva de deterioração da saúde e da diminuição da capacidade funcional para o trabalho durante e após fusão organizacional, aumentando o risco para adoecimento (VÄÄNÄNEN e col. 2004), (c) baixas taxas de pressão arterial com repercussões negativas no sistema cardiovascular, verificados 
durante a jornada de trabalho (KARLIN e col. 2003; EVANS e STEPTOE 2001; RAU e col. 2001), (d) aumento do absenteísmo justificado por problemas de saúde diversos (VÄÄNÄNEN e col. 2003), (e) desenvolvimento ou agravamento de exaustão emocional e da síndrome do esgotamento profissional (TUMMERS e col. 2003; BARUCH-FELDMAN e col. 2002; CONSTABLE e RUSSEL 1986), (f) surgimento de fadiga associada a conflitos com supervisor (BÜLTMANN e col. 2002), (g) desenvolvimento de dores lombares durante o trabalho, associadas com pouco apoio de supervisão (ELFERING e col. 2002), (h) aumento do risco de desenvolvimento de problemas cardíacos, associado com altos níveis de ansiedade e depressão durante o trabalho e de morte por doenças cardiovasculares (EVANS e STEPTOE 2001; THEORELL e KARASEK, 1996), (i) aumento do risco de adoecimento físico e mental (DOLLARD e col. 2000), (j) associação com síndrome do edifício doente no local de trabalho (MENDELSON e col. 2000), (k) aumento da concentração de glicose sanguínea (HbA1c) e risco de doenças cardiovasculares (KAWAKAMI e col. 2000), (1) aumento de distresse relacionado com aumento de tensão e baixa capacidade de desempenho autopercebida (VERMEULEN e MUSTARD 2000; SEARLE e col. 1999; NORBECK 1985), (m) aumento de sintomas depressivos (DORMANN e ZAPF 1999), (n) insatisfação e hostilidade no trabalho (MCCANN e col. 1997), (o) Surgimento de sintomas gastrointestinais, psicossomáticos, deterioração da saúde geral e da qualidade de vida, influenciando o aumento de absenteísmo (UNDÉN 1996).

Efeitos favoráveis à saúde e bem estar relacionados com a presença e/ou percepção de AST: (a) aumento da motivação, satisfação, comprometimento 
organizacional e desempenho autopercebidos durante o trabalho (JONES 2005; BOND e col 2004; YOUREN 2004; TUMMERS e col. 2003; SEARLE e col. 2001; TETRICK e col. 2000; MALLINCKRODT e BENNETT 1992), (b) redução do estresse e das conseqüências negativas para a saúde mental e bem estar psicológico (GAL 2004; LINDORFF 2001; OLSTAD e col. 2001), (c) aumento do uso de estratégias de enfrentamento no ambiente de trabalho e fator de proteção relacionado ao estresse autopercebido (SNOW e col. 2003; PARKERS 1986), (d) aumento da satisfação no trabalho e da produtividade, conforme a fonte do apoio (BOND e col. 2004; BARUCH-FELDMAN e col. 2002), (e) presença de comportamentos seguros na prevenção de acidentes de trabalho (OLIVER e col. 2002), (f) percepção subjetiva positiva sobre desenvolvimento e sucesso na carreira (YOUREN 2004; NABI 2001), (g) diminuição do papel do estresse durante o processo de reestruturação organizacional; aumento de e retorno positivo sobre trabalho realizado e diminuição de retorno negativo na pós-reestruturação (SWANSON e POWER 2001), (h) facilitação da clarificação de papéis quando no excesso de demanda e tensão psicológica (BLIESE e CASTRO 2000), (i) Redução da síndrome do esgotamento profissional e exaustão emocional (DOLLARD e col. 2000; TETRICK e col. 2000), (j) diminuição dos diversos efeitos da alta demanda e baixo controle no trabalho, relacionados com o apoio dos supervisores (SCHAUBROECK e FINK 1998), (k) moderação do humor deprimido no trabalho (ROY e STEPTOE 1994), (1) promoção de saúde mental no trabalho (CHAY 1993; KAUFFMAN e BEEHR 1989), (m) satisfação e significado no trabalho e associação mediadora da pressão no trabalho, ausência de autonomia, ausência de promoção e oportunidades de crescimento na carreira (BOUMANS e LANDEWEERD 1992; LIM 1996), (n) promoção de bem- 
estar (DANIELS e GUPPY 1994; LOSCOCCO e SPITZ 1990), (o) diminuição de níveis de ansiedade no trabalho (MCINTOSH 1990), (p) Moderação do estresse, tensão, disfunções psicológicas e dos agravos à saúde do trabalhador de forma geral (GAL 2004; FRESE 1999; CHISHOLM e col. 1986), (q) promoção de comportamentos saudáveis na população norte-americana, quando comparada com a africana (JAMES 1997), (r) impacto favorável no otimismo na carreira de gerentes do sexo feminino (FRIEDMAN e col. 1998).

Tanto os estudos sobre os aspectos favoráveis quanto os agravos à saúde relacionados com AST sugerem evidências sobre seus efeitos nos processos psicológicos e fisiológicos dos trabalhadores. UCHINO e col. (1999, 1996) realizaram uma meta-análise e identificaram que o apoio social funciona na proteção contra diversas causas de mortalidade advindas de disfunções no sistema cardiovascular, neuroendócrino e imunológico. Já sobre os aspectos psicológicos, LANGFORD e col. (1997) afirmam, em uma meta-análise, que o apoio social é favorável à saúde porque promove a competência pessoal, comportamentos saudáveis, comportamentos de enfrentamento efetivos, controle percebido, senso de estabilidade, reconhecimento de autovalia, afetividade positiva, bem estar psicológico e diminuição de ansiedade e depressão.

Apesar da importância do apoio social para a saúde dos trabalhadores em diversos contextos ocupacionais, ressalta-se que as relações sociais no ambiente de trabalho estão sendo prejudicadas com a precarização da organização e condições de trabalho (KARLIN e col. 2003; SORJ 2000; RIGOTTO 1998; UNDÉN 1996). As 
relações sociais no trabalho podem, portanto, converterem-se em fontes de exigências e estresse e influenciar a saúde, no cotidiano dos trabalhadores (BETRÁN e col. 2004; APPELBERG 1996).

MAISONNEUVE (1977) já considerava que as mudanças no contexto psicossocial influenciam as transformações nas relações humanas. E, para tanto, dois aspectos são ressaltados pela autora: a massificação, em que as relações sociais tendem a se despersonalizarem, fomentando uma situação de "anonimato e de isolamento" e as mudanças nas relações de poder, em que os processos tecnológicos e a informatização suscitam novas formas de controle e poder, abalando o modelo tradicional de autoridade, valores e papéis sociais. Já LANE (1997) assinala a importância das ideologias e das relações de produção enquanto aspectos relevantes. Tais observações corroboram com as afirmativas dos estudos acima citados sobre as repercussões adversas da ausência de AST. Tanto o isolamento social quanto as relações de poder são relevantes para o processo de fornecimento de AST e se relacionam com aspectos da organização do trabalho contemporâneo que favorecem a diminuição da importância do fator humano no trabalho.

A globalização e a reestruturação produtiva são fenômenos que, em suas repercussões sociais, desenvolveram uma miscelânea de modelos de gestão organizacional baseados na ideologia de um modelo produtivo capitalista que favorece a intensificação do trabalho, rotinização, flexibilização e tensionamento do fluxo de produção, exploração da força de trabalho, empreendedorismo, 
tecnocratização, que geram subprodutos como o isolamento social e a desregulamentação nas relações de poder nas organizações.

Por isso, algumas hipóteses indicam possibilidades de que AST esteja diminuindo, bem como seus efeitos de prevenção de adoecimento e promoção da saúde nos trabalhadores (KORTUM 2003). No trabalho, a importância do apoio social é tão relevante que, para DOLLARD e col. (2000), por exemplo, não é necessária a diminuição das demandas no ambiente de trabalho, mas sim o fornecimento de apoio social e controle da tarefa como fatores psicossociais mediadores dos agravos à saúde. Outro exemplo é o de THEORELL (1991), que assinala que o apoio social é um elemento fundamental e decisivo para a implementação e eficiência de programas de promoção de saúde no trabalho.

\subsection{Saúde e trabalho dos professores da educação básica pública:}

Os professores são considerados uma das categorias ocupacionais que sofrem de agravos à saúde muito em decorrência da desregulamentação e precarização das suas relações sociais de trabalho (CARLOTTO 2002; STEPTOE 2000; SILVANY NETO e col. 1998; GREENGLASS e col. 1997; HO 1996; REINHOLD 1996; ORGANIZATIÓN INTERNACIONAL DE TRABAJO 1992, 1986). Segundo o MINISTÉRIO DA SAÚDE (2002, p.534), faz-se necessário "refletir sobre a saúde dos professores, seja individual ou coletivamente... [em que o] estresse diário dos docentes, o esforço repetitivo que o cotidiano exige e o enfrentamento de situações dramáticas" caracterizam o sofrimento no exercício de sua profissão. 


\subsubsection{Aspectos epidemiológicos:}

Segundo o MINISTÉRIO DO TRABALHO E EMPREGO (2003), foram notificados, nos anos de 2001 a 2003, 1081 acidentes de trabalho com professores do ensino básico, sendo que desses, 89 se referiam a doenças relacionadas ao trabalho. Isso significa que as doenças relacionadas ao trabalho de professores do ensino básico são responsáveis por, aproximadamente, $12 \%$ dos registros de acidentes de trabalho com professores. Já o Estado de São Paulo foi responsável por, aproximadamente, $15 \%(\mathrm{n}=702)$ dos acidentes de trabalho com essa categoria, sendo, aproximadamente, 68\% $(\mathrm{n}=61)$ dos casos somente de doenças relacionadas ao trabalho. Para o MINISTÉRIO DA PREVIDÊNCIA SOCIAL (2003), os acidentes de trabalho em professores do ensino básico apresentaram uma incidência de 2,06 em 2003, sendo São Paulo responsável pela segunda maior incidência das UF’S, com incidência de 3,04. A incidência de doenças de trabalho dessa categoria profissional no Estado foi de 0,27.

CODO (1999) identificou que aproximadamente $25 \%$ de professores (amostragem de professores de diversas escolas públicas do país) apresentavam exaustão emocional associada com desvalorização do profissional, baixa auto-estima e ausência de resultados percebidos no trabalho e que aproximadamente $48 \%$ sofrem da síndrome do esgotamento profissional. CARNEIRO (2001) identificou, em Rio Claro/SP, no ano de 2000, 53\% (N=1389) dos atendimentos no setor de Perícia Médica de um Centro de Saúde referiam-se a afastamentos de professores. A autora assinala as possibilidades de um crescente aumento dos afastamentos médicos de 
professores relacionados às repercussões do trabalho desses profissionais em sua saúde. PORTO e col. (2004), identificaram a prevalência de distúrbios vocais (30\%) e LER/DORT (26\%) em prontuários do Centro de Estudos do Trabalhador - CESAT 1991-2001. REIS e col. (2005) identificaram alta prevalência de distúrbios psíquicos menores (55\%) em professores da rede municipal de Vitória da Conquista/BA. GASPARINI e col. (2005) identificaram que, no município de Belo Horizonte, 84\% dos servidores afastados do trabalho educacional são professores, sendo que os transtornos psíquicos ocupam o primeiro lugar (15\%) das patologias diagnosticadas. E, apesar das diferenças entre os índices de adoecimento e afastamento entre as regiões, GASPARINI e col. (2005) assinalam que a maioria das pesquisas que descrevem o perfil de adoecimento dos professores é convergente. Com isso:

Observou-se que os professores têm mais risco de sofrimento psíquico de diferenciados matizes e a prevalência de transtornos psíquicos menores é maior entre eles, quando comparados a outros grupos (GASPARINI e col. 2005).

Esses indicadores refletem a necessidade de se considerar o professor como um trabalhador que sofre em relação à precarização do seu ambiente de trabalho.

\subsubsection{Organização e condições de trabalho:}

A escola pública, como local de trabalho, insere-se nos processos e jogos capitalistas e, apesar disso, é uma instituição que não visa ao lucro nem se 
fundamenta na lógica da mais valia do capital, o que confere um caráter "improdutivo" ao trabalho dos professores (SILVA JR 1993). O "professor como trabalhador improdutivo" é uma questão abordada por SILVA JR (1993). O autor afirma que a atividade e o trabalho do professor público não auxiliam na acumulação do capital, o que tende a fomentar a percepção dos professores de que não há coerência e consistência de políticas educacionais desejáveis.

A administração da escola pública desenvolve-se concorrente com a tecnocratização e burocratização (reflexo da globalização), o que gera discussões acerca da "ideologização da técnica", que traz a prerrogativa de métodos de ensino "mais adequados" e de métodos organizatórios para a "transmissão do saber" (SILVA JR 1993). Isso reflete a necessidade capitalista em perpetuar a expansão acelerada, e que tudo "se passa como se a técnica adequada, uma vez identificada e implantada, pudesse sobrepor às condições concretas do trabalho e dos trabalhadores que o realizam" (SILVA JR 1993, p.51-52). Além disso, PARO (1996) acrescenta à questão da subordinação do ensino ao capital a desqualificação do trabalho do professor porque "na medida em não interessava à classe detentora do poder político e econômico [...] mais que um ensino de baixíssima qualidade, o Estado, como porta voz dos interesses dessa classe, passou a dar cada vez menos importância à educação pública" (p.131).

GIL VILLA (1998) e PARO (1996) assinalam alguns principais indicadores das condições de trabalho dos professores: (a) modificação do papel do professor em sala, (b) contradições da função docente, (c) modificações no apoio social, (d) falta 
de recursos materiais, (e) condições de trabalho limitadoras da atuação profissional, (f) aumento da violência nas instituições escolares e (g) esgotamento diante do acúmulo de exigências na docência. Esse quadro, explicam os autores, refere-se à docência de forma geral, o que resulta em abandono/transferência da profissão, estados ansiosos e/ou deprimidos. GIL VILLA (1998) coloca que a maioria dos professores, do ensino básico, médio ou superior e em diferentes países, sofrem de condições de trabalho semelhantes e deterioradas. No Brasil, SOUZA e col. (2003) assinalam 18 itens relacionados à organização e condições de trabalho potencialmente geradoras de agravos à saúde dos professores: (a) desvalorização do trabalho, (b) pouco reconhecimento social da atividade, (c) baixos salários, (d) centralização das decisões administrativas e pedagógicas, (e) gestão autoritária, (f) diminuição dos espaços de discussão coletiva, (g) tripla jornada, (h) formação deficiente, (i) postura corporal, (j) pó de giz, (k) ruído, (l) turmas superlotadas, (m) inexistência de pausas, (n) culpabilização pelos resultados negativos de desempenho de alunos, (o) invasão de o espaço domiciliar, (p) infra-estrutura precária, (q) burocratização e hierarquização das relações de trabalho e (r) carência de recursos materiais e humanos.

Especificamente, a organização e as condições de trabalho dos professores de educação básica pública, no Brasil, são caracterizadas por (GONÇALVES 2003; SINISCALTO 2000; CAMPOS 1999): (a) alta repetência e evasão de alunos (variando em $15 \%$ e $16 \%$, respectivamente), (b) baixa cobertura da educação e altas taxas de analfabetismo (14\% da população jovem era analfabeta em 1996), (c) formação profissional e curricular inadequado e materiais didáticos desatualizados 
(em 1996, dos 61 mil professores de $1^{\mathrm{a}}$ a $4^{\mathrm{a}}$ série, mais de 50 mil tinham o $2^{\mathrm{o}}$ grau incompleto), (d) falta de participação comunitária na gestão escolar (baixos investimentos públicos e controle financeiro por diferentes agências), (e) alto índice de alunos por sala (f) trabalho em tempo parcial e (g) alto índice de horas trabalhadas por ano $(800 \mathrm{~h} / \mathrm{a})$, quando comparado com outros países.

Devido às características das diretrizes educacionais, os professores de educação básica sofrem da cobrança do dever de adequar seu perfil de trabalho às características e necessidades dos alunos em suas diferentes fases de desenvolvimento, tendo como jargão de trabalho "educar e cuidar" (CAMPOS 1999). A função do ensino básico tem sido desenvolvida por professores de formação "generalista", do sexo feminino, com suas atividades de ensino e cuidado de crianças classificadas como "extensão do papel materno" (maternagem) e de uma organização do trabalho baseada no improviso, exercício simultâneo de tarefas e troca constante de funções, caracterizando certa "domesticidade" (DELCOR e col. 2004; GONÇALVES 2003; CAMPOS 1999; REINHOLD 1996; CARVALHO 1995).

O trabalho no ensino básico se tornou, pois, uma tarefa que exige readaptações do conteúdo do trabalho que não são priorizadas, associadas a uma suposta falta de capacitação e orientação dos professores, em um contexto de descontinuidade e imposição das políticas na implantação das novas propostas educacionais (GONÇALVES 2003). A administração escolar não fornece meios pedagógicos necessários para a realização das tarefas dos professores, o que tende a gerar e a perpetuar o "sobre esforço" ocupacional (GASPARINI e col. 2005). 
CATANI (1998) afirma que as condições de trabalho às quais os docentes estão submetidos são bastante desfavoráveis, sendo que o sofrimento docente relaciona-se, em muito, com a percepção do fracasso no processo de ensino-aprendizagem, até levando, muitas vezes, segundo OLIVEIRA JESUS (1998), ao abandono da profissão.

\subsubsection{Ambiente psicossocial de trabalho e saúde:}

As características do ambiente psicossocial de trabalho podem repercutir na saúde, gerando ou agravando o "mal-estar docente" - termo introduzido por ESTEVE (1992) para caracterizar os efeitos psicológicos em resposta às condições de trabalho docente em longo prazo: estados de ansiedade excessiva, quadros de depressão, cefaléias, hipertensão, taquicardias, insônia, tabagismo e alcoolismo, transtornos mentais e distúrbios vocais (CARLOTTO 2002; JANUÁRIO e col. 2002; GIL VILLA 1998; SILVANY NETO e col. 1998; REINHOLD 1996; CARVALHO 1995; ORGANIZACIÓN INTERNACIONAL DE TRABAJO 1992, 1986). Foram identificadas relações entre o adoecimento dos professores com insatisfação no trabalho, absenteísmo, abandono de profissão, baixa motivação, desinteresse, indisposição física e psicológica constante e perda de sentido e significado do trabalho (CARLOTTO 2002; JANUÁRIO e col. 2002; CODO 1999; SILVANY NETO e col. 1998; REINHOLD 1996; HO 1996; CARVALHO 1995; ESTEVE 1992; ORGANIZACIÓN INTERNACIONAL DE TRABAJO 1992, 1986). 
Alguns fatores relevantes para as repercussões das relações sociais de trabalho na saúde dos professores são: (a) estresse ocupacional crônico, (b) cansaço mental e (c) síndrome do esgotamento profissional (DELCOR e col. 2004; JANUÁRIO e col. 2002; SILVANY NETO e col. 2000, 1998; CODO 1999; REINHOLD 1996; CARVALHO 1995; MCGRATH e col. 1989; ORGANIZACIÓN INTERNACIONAL DE TRABAJO 1981). BARROS (2001); CODO (1999); GIL VILLA (1998); SILVANY NETO e col. (2000) identificaram que as relações entre professores e alunos são aspectos relevantes para os agravos relacionados ao estresse e ao esgotamento profissional.

A síndrome do esgotamento profissional é uma experiência no contexto do trabalho, definida pelo conjunto de sintomas de fadiga física e mental, desmotivação no trabalho, sentimento de impotência, inutilidade e baixa auto-estima (BENEVIDES-PEREIRA 2002). SELIGMANN-SILVA (2003) assinala o aumento da incidência da síndrome do esgotamento profissional, quadros depressivos e transtornos psicossomáticos nos trabalhadores professores, com dados de pesquisas tanto relacionados com a população brasileira quanto internacional. Considera-se que essa síndrome, em professores, é "atualmente um problema social de extrema relevância e vem sendo estudada em diversos países" (CARLOTTO 2002, p.191).

Apesar da importância do sofrimento gerado pela síndrome, uma questão a ser discutida é a possibilidade de ausência de registros sobre nexos causais e diagnósticos do estresse ocupacional crônico e o esgotamento profissional no trabalho de professores. CARNEIRO (2001) assinala o desconhecimento e a falta de 
reconhecimento da síndrome como um importante fator para a ausência de notificações nos sistemas de saúde pública. Segundo PORTO e col. (2004), não foram identificados casos de professores diagnosticados com tais problemas, em pesquisa no Centro de Estudos do Trabalhador - CESAT 1991-2001 - BA, por conta da dificuldade de se assumir o nexo dessas doenças com a profissão.

Em relação específica à saúde dos professores de ensino básico, assinala-se que esses trabalhadores sofrem do estresse e do esgotamento profissional devido, principalmente, às demandas de relacionamento social com funcionários da área de administração (diretoria, coordenação e técnicos administrativos), com os pais dos alunos e com os alunos que, comumente, estão "num período de grande plasticidade" do desenvolvimento infantil (DELCOR e col. 2004; GONÇALVES 2003; CAMPOS 1999; REINHOLD 1996; CARVALHO 1995).

\subsubsection{AST docente:}

AST de professores tem sido descrito como um fator elementar para se compreender o processo de adoecimento dessa classe. GREENGLASS e col. (1998, 1997), BURKE e GREENGLASS (1996,1995), BURKE e col. (1996), SCHWAB e col. (1986), CUNNINGHAM (1983) já identificaram, desde a década de 1980, que o baixo nível de apoio social de fontes entre professores e da diretoria, quando associado a aspectos da organização do trabalho, pode facilitar o desenvolvimento da síndrome do esgotamento profissional. 
Por outro lado, identifica-se a influência de AST não somente relativa à síndrome do esgotamento profissional, mas também à diminuição de sintomas psicológicos como ansiedade, distúrbios do sono, dificuldades nas relações sociais, depressão e ideações suicidas (CHAN e HUI 1998).

BURKE e GREENGLASS (1993) questionam a excessiva importância dada aos efeitos de AST na síndrome do esgotamento profissional, sugerindo a ampliação dos fatores que atuam no modelo determinante da síndrome. De fato, AST mostra-se relevante em diversos aspectos do trabalho dos professores, não somente repercutindo no esgotamento. Pesquisas ressaltam, por exemplo, a relevância do apoio social para os professores relacionado com: (a) a associação de pouco apoio com aumento de dores lombares (TSUBOI e col. 2002), (b) a redução dos efeitos negativos da percepção da sobrecarga de trabalho, amenizando os níveis de estresse e da síndrome do esgotamento profissional (VAN-DICK e WAGNER 2001; HO 1996), (c) a diminuição do impacto do estresse episódico nas taxas de pressão cardiovascular durante a jornada (STEPTOE 2000), (d) a redução da exaustão emocional na síndrome de esgotamento profissional e aumento do comprometimento pessoal (GREENGLASS e col. 1998), (e) a prevenção da síndrome do esgotamento profissional por meio de relações positivas com os colegas de trabalho (GREENGLASS e col. 1997; RUSSEL e col. 1987), (f) o aumento da auto-eficácia percebido no trabalho com alunos e na resolução de problemas do ambiente escolar (KRUGER 1997), (g) o favorecimento do comprometimento organizacional, o qual se relaciona com aumento da satisfação com a escolha profissional e no trabalho, e com o desejo de aprimoramento de habilidades (RAJU e SRIVASTAVA 1994), (h) a 
prevenção da síndrome do esgotamento profissional por meio do retorno positivo sobre o desempenho nas tarefas (RUSSEL e col. 1987).

Os exemplos de AST indicam o papel relevante na prevenção do adoecimento (também relativo à síndrome do esgotamento profissional, mas não exclusivamente), no aumento da satisfação e na melhoria da qualidade de vida no trabalho docente. Pode-se identificar que AST de professores esteve associado, em todas essas pesquisas citadas, à supervisão (diretoria, coordenação) e colegas de trabalho, mas pouco se discute sobre as especificidades do construto quando aplicado à população do professorado, o que dificulta a compreensão da amplitude de uso do mesmo com essa categoria. Questiona-se o papel desempenhado pelos alunos e pais de alunos no apoio social para o professor, bem como a especificidade dos tipos de apoio fornecidos no trabalho. Como tais tipos se caracterizam? Quais são suas dimensões para a classe do professorado e, em específico, para os professores do ensino básico?

\subsection{Problematização da pesquisa:}

Considerando-se a relação entre o sofrimento, adoecimento dos professores e a importância dos fatores psicossociais no trabalho e da organização do trabalho, especificamente de AST e das características do trabalho docente, bem como a necessidade de compreensão da estrutura específica do construto quando aplicado ao professorado, formulou-se a questão: como se caracterizam os conteúdos descritivos de AST docente? 


\section{OBJETIVOS:}

\subsection{Geral:}

Descrever e analisar a estrutura de AST de professores da educação básica pública de uma escola da cidade de São Paulo, por meio de seus conteúdos, utilizando-se de aproximações teóricas entre representações sociais, fatores psicossociais e organização do trabalho docente.

\subsection{Específicos:}

1. Caracterizar as relações sociais com sentido suportivo para a descrição do conteúdo de AST em termos de tipos e fontes disponíveis para os professores da educação básica pública da escola pesquisada.

2. Analisar e comparar os tipos e fontes de AST com a organização e condições de trabalho dos professores.

3. Sugerir estratégias de intervenções psicossociais centradas em AST para professores da educação básica pública. 


\section{MÉTODOS:}

\subsection{Método de pesquisa:}

As pesquisas em apoio social demonstram associações estatísticas com a saúde no trabalho, mas faltam estudos que mostrem em que condições quais efeitos ocorrem relacionados à quais tipos de apoio, por exemplo (HOUSE 1983). THOITS (1995) afirma que se deve buscar um modelo qualitativo de pesquisa para melhor definição dos mecanismos funcionais e estruturais do conceito de apoio social, principalmente no que se refere à compreensão dos aspectos experienciados e construídos coletivamente entre os trabalhadores.

Partindo-se das considerações acima descritas, realizou-se um estudo com as contribuições da pesquisa qualitativa, do tipo estudo de caso, com análises de conteúdo para a descrição de AST pautada no referencial teórico das representações sociais e dos fatores psicossociais/organização e condições de trabalho docente.

Justifica-se o uso das contribuições da pesquisa qualitativa porque se caracteriza como um procedimento de investigação direcionado para os processos e significados sociais os quais não são rigorosamente medidos pelas técnicas estatísticas (DENZIN e LINCOLN 1997). Os autores ressaltam que o referido procedimento tem origem nas pesquisas, análises e entendimentos de padrões de 
conduta e processos sociais. LÜDKE e ANDRÉ (1986) acrescentam ainda o caráter descritivo, de contato direto com o meio social e a ênfase nos estudos das perspectivas dos participantes.

MARSHALL e ROSSMAN (1999) ainda assinalam que a importância da pesquisa qualitativa é para: (a) estudar, de forma aprofundada, fenômenos em suas complexidades e processos, (b) pesquisar fenômenos pouco conhecidos, (c) explorar as diferenças entre conhecimentos sócio-culturais diversificados, (d) pesquisar sobre processos informais e não estruturados, (e) pesquisar sobre o real, em oposição ao formal e (f) substituir as pesquisas que não podem ser feitas experimentalmente e pesquisas em que as variáveis relevantes ainda não foram identificadas. Entende-se que os processos de AST são complexos porque envolvem uma gama de elementos, bem como suas interações, não podendo ser considerado como um

Sugeriu-se que, com a pesquisa qualitativa sobre o apoio social, poder-se-ia identificar e descrever os conteúdos de AST de professores construídos coletivamente. Foram considerados tanto os aspectos tipológicos e as fontes de AST (aqueles referentes ao apoio emocional, instrumental, supervisor, colegas de trabalho etc.) como as características contextuais (condições e organização de trabalho) no trabalho dos professores, fundamentando-se na concepção da representação social enquanto um processo coletivo de negociação de sentidos para a formulação de práticas comunicativas e ações intersubjetivas. Entendeu-se AST como um fator psicossocial mediador das relações entre as características objetivas da organização do trabalho e a percepção subjetiva dos sentidos atribuídos a essas características, 
pelos trabalhadores. Dessa forma, construiu-se um referencial com aproximações teóricas das concepções da literatura científica e da pesquisa realizada, sobre os sentidos atribuídos às características do ambiente de trabalho, principalmente aqueles que se referem às relações sociais suportivas para a execução das tarefas docentes no cotidiano escolar.

Quanto à modalidade de pesquisa, optou-se pelo estudo de caso após a revisão bibliográfica sobre AST de professores da educação básica pública, em que foram considerados como indicadores favoráveis: (a) dificuldade de delimitação e controle experimental do fenômeno, (b) necessidade de contextualização social, (c) natureza coletiva da estrutura do apoio social e (d) limitação de tempo e espaço para a coleta dos dados, tendo em vista os escopos de uma dissertação de mestrado.

Para diversos autores, como YIN (2001), STAKE (2000), MARSHALL e ROSSMAN (1999) e CRESSWELL (1998), a utilidade do estudo de caso se baseia na descrição e compreensão dos padrões de relações dos fenômenos estudados e seus significados para o caso. CRESSWELL (1998) afirma que o estudo de caso qualitativo é um estudo de um sistema delimitado no tempo e no espaço, caso utilizado da coleta de dados em profundidade e detalhamento, envolvendo fonte de dados diversificada. YIN (2001, p.19) afirma que a pesquisa de estudo de caso representa "a estratégia preferida quando se colocam questões do tipo 'como' e 'por que', quando o pesquisador tem pouco controle sobre os eventos e quando o foco se encontra em fenômenos contemporâneos inseridos em algum contexto da vida real". 
Ressalta-se a utilização das contribuições técnicas da pesquisa qualitativa para a descrição dos conteúdos de AST de professores, considerando-se também as limitações impostas por esse objetivo, em contraponto ao amplo espectro de possibilidades de construção metodológica da pesquisa qualitativa. A pesquisa qualitativa "tradicional" não se configura somente na descrição de conteúdos de fenômenos sociais, mas sim uma exploração da construção e o compartilhamento de "significados e intencionalidades" no campo social (MINAYO 2004). MINAYO (2004) ainda assinala que a pesquisa social qualitativa tenta aproximar-se da realidade social de forma histórica, ideológica e, fundamentalmente, baseada na identidade entre sujeito e objeto de pesquisa. Não se orientou por essa vertente da pesquisa qualitativa, fazendo-se somente o uso técnico e a aplicação de tal modalidade de pesquisa.

\subsection{Participantes:}

Esta pesquisa teve a participação de nove professores e da equipe da diretoria. Inicialmente, a diretoria responsável pela escola foi contatada e foi apresentada a proposta de pesquisa à diretoria da escola, bem como solicitada a sua autorização para o início da mesma, consolidada pelo Termo de Consentimento Livre e Esclarecido para a diretoria (anexo A-1). Como a diretoria também foi incluída nas observações e entrevistas, teve-se ainda um outro TCLE específico para a realização das entrevistas e a observações (anexo A-3). 
A participação dos professores foi por livre adesão, que consiste em, após a exposição da proposta da pesquisa, recrutar somente os participantes que opinarem por fazer parte do processo de coleta e devolução dos dados. O convite para colaborar com a pesquisa foi feito pelo pesquisador pessoalmente, numa reunião pedagógica denominada de HTPC - Hora de Trabalho Pedagógico Coletivo, que ocorre semanalmente e tem duração de duas horas, com todos os professores e diretoria. Todos os participantes foram informados, por meio do TCLE específico dos professores (anexo A-5), sobre o tema, os objetivos e os métodos de pesquisa, pesquisador responsável e orientador, e de sua inteira liberdade de participar da observação participante e das entrevistas previstas, além dos demais aspectos éticos envolvidos. O TCLE específico dos professores foi apresentado aos participantes antes da realização da observação participante e da entrevista em profundidade e após serem recrutados segundo manifestação verbal da disponibilidade para a participação.

Justifica-se a relevância de tal número de participantes porque, a priori, para um estudo com contribuições da teoria das representações sociais numa abordagem qualitativa, não existe um número mínimo obrigatório de sujeitos, tal qual se é exigido pelas metodologias fundamentadas nas análises estatísticas (SPINK 2003; SÁ 1998). SOUZA FILHO (1995) afirma que "poucos colaboradores são necessários" porque, complementa SPINK (2003, p.129), quando devidamente contextualizados, formam "um exemplo do que chamamos (...) 'sujeitos genéricos' que (...) têm o poder de representar o grupo no indivíduo”. Ainda, SÁ (1998) 
esclarece a relevância dos "sujeitos genéricos" porque tal tipo de participante da pesquisa está envolvido com o objeto da representação.

Pode-se entender que, para a pesquisa com contribuições do modelo qualitativo e da teoria das representações sociais, um número pequeno de participantes também é relevante metodologicamente porque, mesmo que em pequeno grupo, os participantes são sujeitos portadores do conhecimento e práticas coletivas institucionalizadas e, portanto, fontes fidedignas para referidos estudos.

\subsection{Instrumentos de coleta de dados:}

Pelo fato de ter-se utilizado as contribuições técnicas e as aplicações da pesquisa qualitativa, delineou-se um instrumental para a coleta de dados explorandoos apenas enquanto técnicas favoráveis para a descrição de conteúdos.

Os instrumentos utilizados para a coleta de dados foram: (a) observação participante e (b) entrevistas individuais em profundidade. Para a devolução dos dados foi utilizada a entrevista em grupo. Segue a descrição dos mesmos e as adaptações realizadas para a pesquisa. Ressalta-se que as adaptações dos instrumentos foram feitas conforme as dificuldades e necessidades apresentadas no estudo piloto. 


\subsubsection{Observação participante:}

A observação participante é "o contato direto com o fenômeno observado para obter informações sobre a realidade dos atores sociais em seus próprios contextos" (CRUZ NETO 2002, p.59). Tem origem na antropologia enquanto um

método histórico que procura a inserção, negociação e compartilhamento da interação social entre pesquisador e o grupo estudado em seu meio social e em suas atividades (TAYLOR e BOGDAN 1984). O pesquisador compartilha situações e experiências nem sempre possíveis de serem identificadas e verbalizadas pelos participantes porque se envolve na criação de um vínculo emocional e motivacional com as preocupações do grupo social estudado (YIN 2001; ANGROSINO e PÉREZ 2000; JUDD e col. 1991).

A observação participante exige tempo extenso e negociações com o campo de estudo. Porém, pelas restrições do nível de mestrado, restringiu-se o uso da observação participante enquanto técnica de coleta de dados estruturada para a descrição de ações, comportamentos e verbalizações de indivíduos e grupos (ANGROSINO e PÉREZ 2000; JUDD e col. 1991).

Optou-se por uma variação da técnica, em que o papel do pesquisador foi de observador como participante, em que "a identidade do pesquisador e os objetivos da pesquisa são revelados ao grupo desde o início", tendo que "aceitar o controle do grupo sobre o que será ou não tornado público pela pesquisa" (LÜDKE e ANDRÉ 1986, p.29). Isto implicou em uma relação com o grupo que envolveu a participação 
do cotidiano escolar, mas privilegiando a observação dos fenômenos descritivos do apoio social, aceitando o controle do grupo sobre o que foi revelado para ser utilizado na pesquisa. A observação das condições de trabalho, por meio da descrição dos fatores psicossociais é uma possibilidade para se registrar os dados conforme certos critérios prévios (INTERNATIONAL LABOUR OFFICE 1986). Esses critérios foram delimitados no diário de campo, segundo o estudo de caso-piloto e aspectos da teoria sobre AST.

Apesar de HAGUETTE (1987) afirmar que a observação participante não pressupõe um instrumento específico, como questionário ou roteiro de entrevista, para direcionar a observação, LÜDKE e ANDRÉ (1986) esclarecem que é necessária a delimitação de um foco relacionado com a relevância das informações para os objetivos da pesquisa, diferenciando assim, essa técnica das observações estritamente diretas, em que todos os comportamentos são registrados. Desenvolveu-se e utilizouse um diário de campo adaptado de LÜDKE e ANDRÉ (1986) (anexo A-8) para a coleta de dados da observação. Tal diário foi baseado nos aspectos relevantes do cotidiano escolar conforme identificados no estudo de caso-piloto descrito nos procedimentos de coleta de dados e nos aspectos teóricos da organização do trabalho do professor.

\subsubsection{Entrevista individual em profundidade}

A entrevista individual em profundidade caracteriza-se por processo de interação social, em que o entrevistador tem por objetivos conseguir informações 
junto ao entrevistado (HAGUETTE 1987). Consta de uma enquête individual com questões não diretivas, as quais são centradas em um ou dois pontos específicos para o detalhamento e o aprofundamento da percepção do entrevistado sobre o assunto estudado (YIN 2001; FONTANA e FREY 2000; BRENNER 1985). A questão principal é apresentada (em forma de pergunta ou imperativa) e, com as respostas dadas pelo entrevistado, são investigadas e exploradas outras questões emergentes para a clarificação da temática abordada (FONTANA e FREY 1994; BRENNER 1985). Sugere-se o uso de um roteiro de entrevista que contenha os tópicos a serem abordados (BRENNER 1985).

O roteiro de entrevista proposto para esta pesquisa (anexo A-7) constou da temática central (AST de professores) que foi inicialmente investigado com uma única afirmativa prévia: "gostaria que você comentasse sobre o seu trabalho". Com as respostas dadas, foram exploradas as questões relativas: (a) aos componentes das relações sociais com sentido suportivo e (b) à forma como o entrevistado sente e lida com as relações sociais no trabalho. Tais questões foram definidas previamente conforme o escopo teórico adotado e foram rearranjadas conforme aspectos relevantes observados com o estudo de caso-piloto descrito nos procedimentos de coleta de dados. Anteriormente, a questão prévia seria “comente seus relacionamentos com o pessoal de seu trabalho", mas se identificou que tal questão fomentava respostas diretivas e pouco aprofundadas sobre o assunto, criando um campo de tensão emocional para o entrevistado, durante o estudo piloto. 


\subsection{Entrevista em grupo para devolução dos dados:}

A entrevista em grupo é caracterizada pela enquête em grupo, em que cada participante expressa sua opinião para o grupo e o pesquisador fomenta a discussão sobre os temas abordados na entrevista. A técnica consiste na proposição de uma temática para ser discutida (FONTANA e FREY 2000).

Neste caso, a entrevista em grupo foi utilizada com os participantes da pesquisa, para a comunicação e consolidação dos dados de pesquisa. Com isso, pretendeu-se um modo de legitimação dos resultados com os participantes, de modo a realizar o compromisso ético de divulgação dos dados para os mesmos. Os dados divulgados foram os de caráter coletivo, já tratados e analisados sobre o referencial teórico específico.

\subsection{Procedimentos de coleta de dados:}

Foi realizado um estudo de caso-piloto e, em seguida, o estudo da escolacaso. Em ambos, foram aplicados os mesmos instrumentos de coleta de dados. As contribuições do estudo de caso-piloto são descritas no item 5.1 do capítulo "Resultados". 


\subsubsection{Estudo de caso-piloto:}

O estudo de caso-piloto tem por objetivos: (a) afinar a concepção e aprimorar os instrumentos da pesquisa, (b) reformular e consolidar as questões das entrevistas e serem aplicadas e (c) elucidar aspectos conceptuais do projeto (YIN 2001). Optou-se pelo estudo de caso-piloto para a experimentação e treino técnicos dos instrumentos da pesquisa, além de se levantar alguns aspectos a serem mais bem explorados nas entrevistas e observações.

Nesta pesquisa, o caso-piloto foi realizado numa escola diferente da escolacaso. A diretoria do caso-piloto foi contatada e aspectos éticos e de procedimento foram explicitados. Após o aceite para a pesquisa, realizou-se uma observação participante de uma jornada de trabalho (das 19h40min até às 22h50min) e uma entrevista em profundidade, que durou, aproximadamente, 65 minutos, com um professor selecionado por meio da livre-adesão ao convite para participar da pesquisa.

Os dados coletados foram analisados com o intuito de delimitar e delinear as questões da entrevista em profundidade e a entrevista em grupo, bem como aspectos relevantes para a observação participante. 


\subsubsection{Estudo da escola-caso:}

Inicialmente, foi feita a observação participante da jornada de trabalho de dois professores escolhidos previamente segundo o critério de maior e menor tempo de trabalho na função/escola, dentre os professores que optaram por participar da pesquisa. Os dados foram registrados por meio de anotações feitas no diário de campo. Após essas duas observações, continuou-se com as observações, procurandose a inserção no grupo de professores. O pesquisador permaneceu em locais considerados de encontro coletivo, como a sala dos professores e reuniões pedagógicas de HTPC. Todas as observações participantes ocorreram num período de três meses, uma vez por semana, de agosto a outubro de 2005, totalizando 14 dias de observações. As observações foram realizadas no período da manhã, e os dados registrados foram somente os que se referiam aos nove professores que aceitaram participar da pesquisa com seus consentimentos, bem como aquilo que foi permitido por eles, durante as observações, ser anotado no diário de campo. Dessa forma, alguns dados foram inutilizados e/ou perdidos por terem sido vetados pelos participantes. Levantam-se algumas hipóteses sobre tal dificuldade, como o pouco tempo de inserção no campo, as restrições prévias dos professores e da diretoria, devido a experiências adversas com outros pesquisadores.

Durante esse mesmo período, também se realizou a entrevista em profundidade individualmente com os nove professores. Os dados foram registrados por meio de gravador digital de voz e por anotações manuscritas realizadas durante a entrevista. Foram realizadas duas entrevistas com a direção e uma com a 
coordenação. Após a coleta desses dados, procedeu-se às análises para a construção dos componentes de AST docente. Por fim, realizou-se a entrevista coletiva para a devolução e consolidação dos dados de pesquisa.

\subsection{Aspectos éticos:}

A ética em pesquisa na área de saúde e com seres humanos relaciona-se com o direto humano. FRANÇA JÚNIOR e AYRES (2003, p.67) assinalam que a "ampliação dos conhecimentos em saúde pública pode ser tomada como direito social. Todavia, muitas vezes para produzi-lo podemos violar outros direitos sociais ou direitos da esfera privada". Os autores se referem à necessidade de se tornar público o conhecimento adquirido com os participantes de uma pesquisa, mas que tal necessidade não deve sobrepor-se ao direito individual para que a privacidade dos participantes não seja invadida. Os autores alertam que tal invasão pode resultar em estigmatização, discriminação, perda de emprego e relações afetivo-familiares para os participantes. Disso decorrem todas as possíveis precauções e cuidados para com a divulgação dos dados da pesquisa, além do compromisso ético formal assumido por meio dos TCLE.

Os professores que concordaram em participar da pesquisa foram esclarecidos sobre os objetivos deste projeto antes de começar a pesquisa. Receberam também informações sobre os procedimentos e os possíveis benefícios decorrentes. Também tiveram garantido seus direitos de confidencialidade, como também o consentimento de poder abandonar a pesquisa no momento em que 
desejassem. O pesquisador se comprometeu a divulgar os resultados da pesquisa para os participantes e para a diretoria.

\subsection{Procedimentos de análise dos dados:}

\subsubsection{Referencial teórico:}

Pelo fato de AST ser um conceito que envolve a identificação e compreensão do sentido suportivo das relações sociais nos contextos de trabalho, HUTCHINSON (1999) sugere a prioridade de análises do apoio social embasadas nas teorias da psicologia social, agregando um referencial teórico de base à concepção do conceito. Além disso, THOITS (1995) assinala a necessidade das pesquisas compreenderem a forma como as pessoas percebem o apoio social. LINDORFF (2001) e JACOBSON (1986) também assinalam que a mobilização, percepção e aceitação do conteúdo do apoio estão vinculadas à construção individual e coletiva de relações sociais com sentidos suportivos. Para uma construção de referencial que privilegiasse tais aspectos, optou-se pela teoria das representações sociais.

JODELET (1988) assinala que a teoria das representações sociais estabelece uma relação entre o psicológico e o social, ou seja, a "interface dos fenômenos individual e coletivo" (SPINK 1993, p.300).

A teoria das reapresentações sociais tem origem no pensamento sociológico de E. Durkheim, na década de 1960 (MOSCOVICI 2003, 1978). Moscovici (2003, 
p.49) contrapôs-se à concepção sociológica de que as representações coletivas são um "instrumento explanatório e se referem a uma classe geral de idéias e crenças". O autor procurou compreender e estudar os fenômenos coletivos que "corporificam" idéias e experiências coletivas e interações com o comportamento, para se compreender comunicar e tornar familiar o não familiar.

As representações sociais constituem, pois, um fenômeno social que expressa a percepção e a compreensão de um grupo sobre sua relação com os objetos, na construção de uma realidade social, por meio de imagens, conceitos e categorias que formam um conjunto de palavras, sentimentos e condutas institucionalizados (MOSCOVICI 2003, 1978; SÁ 1995). São “fenômenos específicos que estão relacionados com um modo particular de compreender e de se comunicar - um modo que cria tanto a realidade quanto o senso comum" (MOSCOVICI 2003, p.49).

Segundo MOSCOVICI (1978), as representações sociais estão baseadas no processo de mediação social e estruturam-se como um "conhecimento particular que tem por função a elaboração de comportamentos e a comunicação entre indivíduos" (p.16), funcionando como a "preparação para a ação [...] à medida de que remodela e reconstitui os elementos do meio ambiente em que o comportamento deve ter lugar" (p.49). É “o conjunto de pensamentos e sentimentos expressos em comportamentos verbais e abertos de atores, os quais constituem um objeto para um grupo social [...], um fenômeno coletivo pertencente a uma comunidade, o qual é co-construído por indivíduos nas suas conversas e ações cotidianas” (WAGNER e col. 1999, p.96). 
MOSCOVICI (1978) complementa que as representações sociais formam um sistema de valores, idéias e práticas com objetivos de estabelecer uma ordem que ajuda as pessoas a se orientarem e controlarem o mundo material e social e a comunicarem-se, ou seja, são teorias do senso comum.

Inicialmente, as representações sociais foram concebidas conforme um modelo cognitivista, o qual sofreu mudanças relativas à inclusão de aspectos conceituais da psicanálise, com as próprias constatações de MOSCOVICI (1989) em LANE (1995), referentes à intersecção das representações socais com as contribuições da psicanálise. A autora afirma que a proposta dessa intersecção é de considerar aspectos inconscientes afetivos e emocionais com os aspectos cognitivos. JODELET (1988) esclarece que se decorreu uma evolução conceptual das representações sociais que englobou a articulação de "elementos afetivos, mentais e sociais" interados ao lado da cognição, linguagem e comunicação, ou seja, os aspectos sociais, materiais e ideais da realidade.

JODELET (1988) afirma que as representações sociais são uma maneira de se interpretar e pensar a realidade de forma coletiva, um "conhecimento social" que condensa um conjunto de significados que servem de referência para interpretar a vida diária e dar "sentido ao inesperado". "As representações sociais constituem modalidades de pensamento prático orientados para a comunicação, a compreensão e o domínio do entorno social, material e ideal" (JODELET 1988, p.474). SPINK (1995, 1993) complementa essas idéias assinalando que são formas de conhecimento 
prático que orientam as ações cotidianas, tanto por serem campos socialmente estruturados quanto por expressarem a realidade intra-individual.

Para SÁ (1995), a teoria das representações sociais se refere tanto a um conjunto de fenômenos - relações informais, cotidianas, em níveis sócio-culturais quanto à teoria para explicá-los. $\mathrm{O}$ autor esclarece que as representações sociais atuam na construção social da realidade incorporando o conhecimento não familiar aos universos consensuais, quando então "operam os processos pelos quais ele passa a ser familiar, perde a novidade, torna-se socialmente conhecido e real” (SÁ 1995, p.37).

BAUER e GASKELL (1999) assinalam a relação entre três elementos como característicos das representações sociais: sujeitos $(\mathrm{S})$, objeto $(\mathrm{O})$ e projeto ou contexto pragmático (P). Para os autores, os sujeitos são aqueles que carregam certa representação social de um determinado objeto (concreto ou idéia abstrata) e que estão inseridos em um projeto ou contexto pragmático de um grupo social no qual a representação faz um sentido. Entendem que "sujeito, objeto e projeto formam um sistema de constituição mútua" (BAUER e GASKELL 1999, p.168). Para JODELET (1988), esse sistema se articula sobre um modelo de conhecimento do cotidiano, socialmente elaborado e compartilhado, constituído tanto pelas experiências individuais quanto informações, modelos de pensamentos que recebemos pela tradição, educação e comunicação social. 
Percebe-se que existem diversas e diferentes definições de representação social. LIU (2004) se refere às dificuldades de definição do conceito de representações sociais, aludindo-se à própria referência múltipla de definições de Moscovici. Disso decorrem críticas em relação à imprecisão conceitual das representações sociais. A autora propõe a idéia de que a definição de representações sociais está no âmbito de um conceito sensibilizador (sensitizing concept): são conceitos que não contém uma especificação precisa de seu objeto; eles remetem a uma idéia geral de referência num molde empírico, ou seja, esses conceitos, como o caso das representações sociais, relacionam-se com o mundo empírico aos quais se remetem para interpretar as dinâmicas do mundo social.

Para MOSCOVICI (1978), a estrutura de cada representação se refere à díade figura e significado e a construção das representações sociais está pautada em dois processos: a ancoragem e a objetivação. JODELET (1988) e MOSCOVICI (1978) explicam que a ancoragem diz respeito ao fornecimento de um contexto a um objeto, sua interpretação e integração cognitiva. SÁ (1995) assinala que MOSCOVICI (1985) dividiu o processo de ancoragem em dois sub-processos: (a) classificação, que é o processo de comparação e aceitação do novo conteúdo representacional com "protótipos" armazenados na memória; (b) denominação, que é a inclusão do novo conteúdo representacional em um "complexo de palavras específicas" para tirá-lo do “anonimato perturbador". JODELET (1988) e MOSCOVICI (1978) assinalam que a objetivação se caracteriza pelo processo de dar materialidade a um objeto abstrato, tornando-o uma forma ou figura (o objeto da representação social pode ser idéias, acontecimentos, pessoas, relações etc.). Os autores também esclarecem que a 
objetivação é uma operação imaginante e, ao mesmo tempo, uma qualidade icônica da formação da figura acerca do objeto da representação.

Sobre a gênese das representações sociais, SÁ (1995) explica que Moscovici considera o pensamento coletivo nem uma extensão das ideologias sociais dominantes - olhar sociológico - nem uma mente do tipo "caixa preta", que processa informações em julgamentos - olhar psicológico. Sá ainda esclarece que Moscovici entende os indivíduos como pensadores ativos que, em seu cotidiano de interações sociais, criam representações específicas para suas questões.

BAUER e GASKELL (1999) assinalam que as representações sociais são cultivadas nos sistemas de comunicação, portam conteúdos estruturais que funcionam tanto para os sistemas de comunicação quanto para seus participantes e são incorporadas de diferentes modos e meios. Os autores explicam que, nos sistemas de comunicação, também entendidos como contextos sociais, as representações sociais são elaboradas, circuladas e recebidas num processo simbólico, sendo incorporadas em comportamentos habituais, pensamentos individuais e comunicação formal e informal. Acrescentam, também, os modos de representações: movimentos, palavras, imagens visuais e sons não lingüísticos. Também assinalam que o sistema mínimo envolvido em uma representação é uma tríade: dois sujeitos preocupados com um objeto, em que se construirá um significado comum. 
ABRIC (1994) assinala que as representações sociais são estruturas norteadoras das práticas coletivas por ser um sistema de interpretação compartilhado da realidade que relaciona o individual com o ambiente físico e social.

Porém, SPINK $(1995,1993)$ assinala que o processo de elaboração das representações sociais engloba a contextualização sócio-histórica e os discursos constituintes das relações sociais. Também assinala que esse processo é contraditório porque o senso comum é diversificado, compreendendo sua lógica e coerência e também suas contradições. Por isso, a autora sugere que o estudo das representações sociais não se direcione para suas estruturas, mas sim para suas práticas, ou seja, "a funcionalidade das representações sociais na orientação da ação e da comunicação" (SPINK 1995, p.123). Com isso, a autora imprime uma crítica ao representacionismo baseado no estruturalismo. ALVES e RABELO (1998) partilham do mesmo posicionamento teórico acerca dos estudos sobre representações, principalmente porque muitos autores estabelecem uma dicotomia entre a estrutura representacional e as práticas. Os autores afirmam que os processos de saúde e doença se constituem também em sentidos alicerçados no caráter polissêmico e subjetivo da produção discursiva. SPINK (1996, p.179) propõe uma abordagem das representações sociais, fundamentada nas propostas construcionistas, com a qual se pode considerar "não apenas os conteúdos das representações, como também o contexto de produção e a funcionalidade destes conteúdos na interação e comunicação". A autora entende que o discurso passa a ser considerado como uma produção e uma prática coletiva na produção e negociação de sentidos, o que favorece uma metodologia fundamentada nas interações discursivas e coletivas no "aqui-e-agora". 
Entendeu-se que as relações sociais ocorrem na intersecção entre os sentidos particulares e coletivos atribuídos e negociados para a compreensão e a constituição das interações e comunicações cotidianas, construindo uma realidade social característica de um grupo sócio-historicamente determinado. Procurou-se, com a teoria das representações sociais, portanto, compreender os sentidos atribuídos às relações sociais capazes de descrever tipos e conteúdos de AST docente, por meio da análise qualitativa do conteúdo dos diálogos embutidos no material coletado.

\subsubsection{Proposta de análise da observação participante:}

Os dados coletados foram submetidos a um processo de análise de conteúdo. A análise de conteúdo, segundo BAUER (2003), é o processo de produzir inferências do texto focal para o seu contexto social. O autor cita que esse processo pode reconstruir representações, seus valores, atitudes e opiniões e compará-los entre a comunidade. Foram evidenciadas nas falas e ações registradas no diário de campo, as construções do conhecimento e sentidos que indicaram um caráter de apoio presente nas relações sociais no trabalho. As categorias de análise (tipos e fontes de apoio) foram definidas a priori, segundo a sistematização de HOUSE (1983) e a posterior, na construção de novas categorias. Foram consideradas, como relações de apoio, aquelas em que as falas e ações dos professores relacionaram-se com o sentido de provisão (ou ausência) de instrumentos, informações, trocas afetivas, de apreciação sobre trabalho realizado, além de suas fontes (HOUSE 1983). 


\subsubsection{Proposta de análise da entrevista individual em profundidade:}

Também foi realizada uma análise de conteúdo no texto das entrevistas. Segundo BAUER (2003), numa análise de conteúdo, deve-se: (a) relacionar teoria e as circunstâncias da pesquisa para identificar a seleção do texto específico, (b) construir um referencial de codificação ajustado tanto à teoria quanto ao material pesquisado, (c) fazer um teste e refinar a codificação, (d) testar a fidedignidade e cuidar para evitar ambigüidades e (e) codificar todo o material coletado.

Para as entrevistas, a codificação foi criada com base na proposta de SPINK (2003): (a) transcrição, (b) leitura do material para verificar a construção do discurso (silêncios, hesitações, lapsos, as variações e a forma como o discurso se orienta para a ação), a retórica (a organização do discurso) e a emergência dos investimentos afetivos. A codificação baseou-se em categorias prévias (tipos e fontes de apoio), segundo HOUSE (1983), e na construção de novas categorias a posterior. Foram consideradas como relações de apoio aquelas em que as falas e ações dos professores estiveram relacionadas com a percepção dos mesmos sobre a provisão (ou falta de) aspectos materiais, emocionais, de apreciação sobre o trabalho e informações para a execução das tarefas no trabalho, além da identificação de suas fontes.

\subsubsection{Triangulação e síntese dos dados:}

Os dados coletados foram analisados em conjunto em suas categorias estabelecidas com a análise de conteúdo e suas relações com aspectos teóricos de 
AST. Procurou-se identificar não somente as falas sobre as relações sociais de apoio no trabalho, mas também aquelas que indicavam, indiretamente, a ocorrência de um aspecto de apoio social, conforme descrito na teoria. Para tanto, extraiu-se das observações participantes e das entrevistas em profundidade, categorias com as quais se delinearam aspectos estruturais, em termo de tipos de conteúdo e fontes, de apoio no trabalho dos professores com base nas relações de construção de sentidos nas dimensões discursivas e ações, aspectos do conhecimento prático dos professores sobre seu cotidiano de trabalho e investimentos afetivos contidos nas relações sociais. Também se articulou e se justificaram as possibilidades de desenvolvimento de técnicas de intervenção, com base na relação entre os dados coletados, fatores psicossociais e organização do trabalho dos professores. 


\section{ESTUDO DO CASO-PILOTO:}

Com o estudo do caso piloto, pode-se delinear algumas questões referentes aos procedimentos de coleta de dados, que já foram ajustados na descrição dos mesmos. Apresentam-se, a seguir, as contribuições do piloto para a construção dos instrumentos desta pesquisa:

1. Os dados da observação participante devem ser coletados tanto em situação coletiva (interações entre os professores e reuniões pedagógicas) quanto em situação individual (acompanhamento de jornada de trabalho para inserção no campo e aquisição de confiança dos participantes).

2. A observação participante deve ser o eixo principal da pesquisa e as entrevistas devem ocorrem em caráter de complementação dos dados inicialmente coletados com a observação. Isso implica em selecionar os entrevistados conforme a relevância do mesmo para a compreensão do apoio social na escola.

3. Tanto o modelo de diário de campo quanto o roteiro da entrevista em profundidade foram adequados para esclarecimento dos aspectos relacionados ao apoio social. Porém, as questões sobre saúde e adoecimento no trabalho docente deverão ser perguntadas diretamente, caso os entrevistados não a abordem. 


\section{RESULTADOS:}

Estudou-se uma escola da região oeste da cidade de São Paulo. É uma escola que atende a crianças da periferia da cidade, ou seja, crianças de famílias de baixo nível sócio-econômico. Possui 13 salas de aula, uma cozinha, sala da diretoria, secretaria, estacionamento, uma quadra desportiva e uma biblioteca. Ainda apresenta uma sala para guardar materiais diversos. A sala dos professores se localiza em frente ao estacionamento e à sala de reuniões/vídeo. Na entrada pode-se ver o pátio, a cozinha e a biblioteca. Próximo a elas estão a secretaria e a sala da diretoria. A escola, incluindo as salas de aula, apresenta um aspecto mais antigo, rústico, com paredes sujas e rabiscadas, bem como as carteiras e as lousas visivelmente desgastadas.

A sala da diretoria possui três mesas, um computador e dois armários. A sala dos professores contém uma mesa de centro e alguns quadros de avisos. Também possui um armário e uma prateleira com alguns materiais didáticos aparentemente antigos e não mais utilizados.

Pela manhã, encontram-se 15 professores para o ensino nas primeiras, segundas, terceiras e quartas séries. São professores que se mostram vestidos de maneira bastante simples. 12 são do sexo feminino e três do masculino, sendo que o grupo tem idade variando entre 26 e 58 anos. Para as análises, não interessou por fazer uma distinção entre idade e sexo dos participantes da pesquisa, para preservar quaisquer possibilidades de rompimento do anonimato dos participantes. 
A negociação da pesquisa foi realizada, inicialmente, com a diretoria, composta de um coordenador, um vice-diretor e um diretor. Todos os aspectos éticos e a apresentação da proposta de pesquisa foram esclarecidos. Não foram colocados obstáculos para os procedimentos, por parte da diretoria. Somente a condição dos professores aceitarem ou não. Isso porque, segundo a diretoria, eles "ouvem" diversos casos de pesquisadores que vão para as escolas públicas e acabam por "revelar" aspectos da pesquisa que comprometeriam as relações sociais nas escolas. Percebeu-se certa preocupação inicial da diretoria em resguardá-los.

Em seguida, combinou-se de se apresentar o pesquisador para os professores na próxima reunião de HTPC. Nessa reunião, após a apresentação das propostas para os professores da manhã, houve questionamentos sobre a questão do sigilo e a preocupação de "vazamento" de informações. Com isso, dos 15 professores, nove se prontificaram a participar da pesquisa. Mesmo sendo assegurados dos aspectos da confidencialidade do projeto, solicitaram que não fossem divulgados quaisquer dados que possibilitassem a identificação da escola e dos professores, citando o caso de uma escola que conheciam, onde os dados de uma pesquisa realizada foram lidos pela diretoria, que identificou os docentes envolvidos e suas falas, criando uma situação desagradável no ambiente de trabalho. Concordou-se com tal anonimato, o que determinou a forma de escrita desta dissertação, propondo-se um olhar descritivo dos eventos e ações dos colaboradores, com a preocupação de manter o total anonimato das falas. Para tanto, todos os professores foram identificados pela palavra "professor (a)" e os membros da diretoria (coordenador, vice-diretor e diretor) pela palavra "diretoria". 


\subsection{Categorias descritivas de AST:}

\subsubsection{Tipos de apoio:}

\subsubsection{Apoio emocional:}

Caracterizou-se pela liberdade, espontaneidade e informalidade da expressão e compartilhamento de conteúdos afetivos relativos ao cotidiano dos professores, principalmente quando relacionado com as exigências consideradas excessivas advindas da relação de cuidado existente entre professor-aluno.

Diálogo entre professores (as): "Não sei mais o que fazer com eles." reclama um (a) professor (a). "Eu já percebi que nada mais adianta, somente ir aos berros, no grito mesmo! Aí sim eles param." - conforta outro (a) professor (a). "Nessas horas a única coisa que resolve é isso. Não adianta mais nada!" continuou. "Os meus estão impossíveis! Não vejo a hora de tirar aquela minha folga!" - responde o (a) primeiro (a). "É..., mas você tem que tomar cuidado porque nessas de trabalhar a mais aqui e ali, acabam perdendo a sua folga e aí...". complementa o (a) segundo (a).

Diálogo entre professores (as): "Você sentiu minha falta ontem, [...]?” perguntou o (a) professor (a). "Sim, tive que ficar com eles até a última aula. Aí ninguém agüenta mais" - respondeu. “É, eu não estou mais agüentando mesmo... parece que eu falo e eles não escutam nada, nem mesmo respondem”. 
Professor (a): "Geralmente eu converso com a vizinha de sala [...]. A gente chora as pitanga, reclama um pouquinho ali e depois passa”.

Professor (a): "Sempre a vizinha do lado [...]. Às vezes vou atrás dela. Quando fico apavorad [...] vou atrás dela e falo 'pelo amor de Deus'. [...] Quando alguém aparece na porta aí eu falo 'não agüento mais'.

\subsubsection{Apoio instrumental:}

O fornecimento de instrumentos para a realização das tarefas prescritas no trabalho se caracterizou por trocas de: (a) favores de substituição de professor em sala de aula, porque a substituição do professor por outro colega de trabalho foi um instrumento de apoio para que pudesse se retirar da sala sem dispensar os alunos, (b) materiais pedagógicos, como livros, apostilas etc., (c) materiais não disponíveis ou inexistentes na escola, como cópias xerocadas de material pedagógico etc. (d) procedimentos pedagógicos, como técnicas de controle de indisciplina e métodos avaliativos.

Diálogo entre professores (as), sobre um procedimento pedagógico diferente para corrigir as lições de casa que um (a) ensinou para o (a) outro (a): "Não ficou mais fácil corrigir no caderno?" - pergunta a (o) professor (a). "Sim, bem mais fácil! O difícil é levar tudo pra casa..." - reafirma o (a) segundo (a). 
Professor (a): "Quando tenho algum problema, peço pra [...] ficar com minha sala, aí eu posso sair da sala, sabe como é, né?. E se [...] precisa, também olho a sala [de outro professor (a)] pra poder ir no banheiro ou falar com [outro professor (a)]”.

Diálogo entre professores (as), comparando as classes de reforços: "Como estão os seus do reforço? Estão aprendendo alguma coisa?” - pergunta um (a) professor (a). "Sim!" - responde o (a) outro (a). "Então deixa eu saber como você está fazendo, porque com os meus está difícil” - desabafa o (a) primeiro (a).

Professor (a): "Quando alguém tem alguma coisa diferente, a gente sempre passa pros outros [referindo-se a livros e apostilas para usar com os alunos]”.

Professor (a): "Quando eu preciso de tirar xerox, falo com [a diretoria] e [...] diz pra mandar fazer que [...] dá um jeito”.

Mesmo com a troca de materiais, os (as) professores (as) percebem as limitações de recursos para as aulas. Além disso, também percebem certa insatisfação com o material didático comum a todos, procurando por outras possibilidades:

Professor (a): "Geralmente a gente tem o material didático [...] o livro a gente não usa com série nenhuma. Eu não sigo um livro, porque seguir um livro, aí fica meio, parece que a gente fica meio em cima do livro [...] e não usar um 
determinado livro, aí eu posso diversificar melhor. Pega um pedaço de um livro, pega uma parte de outro, pega às vezes material que não é de livro, recortes de revista, jornais, para eles também acessarem outros tipos de texto”.

Professor (a): "Pesquiso em outros livros, na internet, peço para a escola e em último caso compro!”.

\subsubsection{Apoio de apreciação:}

O fornecimento de apreciação sobre trabalho realizado dos professores ocorreu informalmente, entre as conversas cotidianas na sala dos professores, e formalmente, nas reuniões de HTPC - Horário de Trabalho Pedagógico Coletivo. No HTPC, a diretoria explica e discute sua percepção sobre o desempenho dos professores. Tanto a diretoria quanto os professores avaliam seu desempenho com base no manejo com os alunos, propostas de atividades educacionais, sentimentos e pensamentos dos professores sobre si próprios e a avaliação anual de desempenho dos alunos, realizada pelo Governo do Estado de São Paulo (SARESP). Os professores utilizam o desempenho dos alunos e a receptividade da classe às propostas de trabalho como indicadores do desempenho profissional, além do uso do caderno volante, em que cada dia um aluno de cada classe escreve, para ser avaliado pela diretoria.

Diálogo entre professor (a) e diretoria: "Olha o que ele [refere-se ao caderno de um aluno] fez! Ficou uma droga! Aí falei para ele que tinha capacidade para 
fazer direito, mas que ele não podia deixar de fazer ou fazer mal feito. Só conversei com ele e não repreendi: não sei se fiz certo..." - diz o (a) professor (a). "Sim, isso mesmo! É melhor você fazer assim. Tá mais certo [...] porque se você repreender, ele vai continuar te desafiando" - explica a diretoria.

Professor (a): "Procuro fazer uma avaliação diária. Converso muito com alguns colegas e com [a diretoria]. Também tomo como parâmetro o interesse do aluno, a realização das atividades propostas".

Professor (a): “Eu planejo. Tem um monte de coisas que a gente pode falar. Mas daí a pouco eu começo a falar e parece que não está chamando a atenção. Se eles não prestam a atenção, saio devendo”.

Professor (a): “A [diretoria] tem acompanhado, mais ou menos, essa parte no caderno volante que a gente faz. Cada dia um aluno escreve. É mais a parte de como está e também de como é a sala, o que cada um ta fazendo na sala”.

\subsubsection{Apoio informativo:}

O fornecimento de informações referentes ao trabalho dos professores ocorreu formal ou informalmente durante a jornada de trabalho. Formalmente, a diretoria utilizou-se do HTPC - Horário de Trabalho Pedagógico Coletivo - para informar aos professores sobre: (a) calendário escolar (feriados, emendas, férias, 
recessos, início e término do ano letivo, etc.) (b) trabalhos e propostas pedagógicas coletivas (comemoração de festas temáticas como o dia do índio e a independência, teatros, cinemas, exposições e realizações de trabalhos dos alunos como temas sobre o lixo, a cidadania, a preservação da natureza e o transporte coletivo, e possibilidades didáticas diversificadas, como planos e abordagens pedagógicas cotidianas) e (c) aspectos burocráticos relativos a procedimentos com a secretaria (férias, abonos, afastamentos e retornos ao trabalho). Informalmente, os professores trocam esses tipos de informações entre si durante a jornada de trabalho e, na sala dos professores, existe um quadro para afixação (por parte da diretoria) de informativos diversos sobre o trabalho dos professores.

Diálogo entre professores (as), comparando as classes de reforços: "Como estão os seus do reforço? Estão aprendendo alguma coisa?” - pergunta um (a) professor (a). "Sim!" - responde o (a) outro (a). "Então deixa eu saber como você está fazendo, porque com os meus está difícil” - desabafa o (a) primeiro (a).

Diálogo entre professores (as), sobre um feriado: "Bom, [professor (a)]. Agora tem o feriado do dia [...] aí! Vamos ver se o governador vai dar o dia pra gente” - afirma o (a) professor (a). "É, vamos ver. Mas se ele não der, creio que [a diretoria] vai fazer aquele revezamento de uns vem a tarde e outros de manhã" responde o (a) outro (a).

Diálogo entre professores (as) e diretoria, no HTPC, sobre datas do SARESP (avaliação anual de desempenho dos alunos, realizada pelo Governo do Estado de 
São Paulo): “Gente, o SARESP desse ano será no dia [...]. Preciso que os professores (as) da manhã compareçam pela manhã e o da tarde, pela tarde. Temos que vir um dia antes pra arrumar as salas porque o governador não vai enviar o pessoal para ajudar!" - explica a diretoria para os professores (as).

Diretoria: "Eu mesmo faço e coloco esses lembretes na parede da sala dos professores para ajudá-las”.

Diálogo entre professores (as) sobre a festa junina: "Você sabe como vai ser a festa junina?" - pergunta um (a) professor (a). "Olha, pelo que tou sabendo, eles [os alunos] estão ensaiando agora, com o [professor (a)] para a apresentação lá no dia. Parece que cada pai vai ter que levar um doce ou salgado, além das barraquinha que vamos montar [...]" - responde o (a) outro (a). "É, eles [alunos] estão bem agitados lá na sala por causa desses ensaios...”.

\subsubsection{Fontes de apoio:}

\subsubsection{Apoio da diretoria:}

O apoio da diretoria é reconhecido pelos professores e fornecido em termos instrumentais, emocionais, de apreciação sobre trabalho realizado e informativo. Teve por finalidade a regulação das relações entre aluno e professor para diminuir o excesso de exigência do "cuidar e educar" (problemas de indisciplina e dificuldades 
de aprendizagem) e regulação de tempos/modos dos trabalhos (organização, sistematização, planejamento, negociação e consolidação do plano pedagógico).

Diretoria: "Sabe, é essa forma que posso ajudá-las. Se elas não agüentam mais os meninos, então mandem pra mim, porque na minha sala eles ficam quietos $e$ não bagunçam mais. Eu falo isso para elas”.

Diretoria, conversando com os (as) professores (as) numa reunião de HTPC: "Sei que vocês estão cansadas e que muito dos problemas não são de vocês. Essas crianças têm problemas na família e com os pais, que são uns filhas da puta, mas vocês não podem resolver isso. Mandem pra mim! Não briguem com eles, não deixem de castigo, mandem pra mim! Eu também não vou resolver o problema, mas posso amenizá-lo para vocês fazerem seu trabalho”.

Professor (a): “A [diretoria] me ajuda muito... Às vezes [diretoria] dá umas idéias no HTPC pra fazer com os meninos e acho muito boas... Coisas de dinâmicas e exercícios... assim...”.

Professor (a): “Em todas as situações obtive ajuda da direção”.

Para aliviar o excesso de exigências relacionado ao cuidado dos alunos, a diretoria permanece no pátio da escola inspecionando o intervalo das aulas: "[Com isso], evit [amos] [...] que os professores tenham que ficar a todo o momento cuidando dos meninos". 
Por outro lado, existe uma situação de ambigüidade no fornecimento de apoio pela diretoria, principalmente quando a relação entre um determinado professor e a diretoria não está satisfatória.

Diretoria: "Não faço a mínima questão de agradar a [...], [...] e [...]. São [...] do mesmo bando... [...] vagabund [...]s que não querem fazer nada... sabe... colocam o aluno pra fora da sala e deixam o coitado fazendo lição no intervalo... Isso é um absurdo... Aí eu falo pra [...] que eu boicoto mesmo! Falo pra não fazerem isso, mas não adianta!”.

Com esse tipo de argumentação, a diretoria toma uma atitude agressiva e/ou pouco solícita com as demandas desses (as) professores (as), em específico. Muitas vezes, a diretoria se exalta emocionalmente, gritando e usando de ironias com os professores. Também, percebe-se que os professores consideram que algumas das ações da diretoria não resolvem muitos de seus problemas com os alunos.

Professor (a): "E sabe como é [a diretoria], se colocamos o aluno pra fora, não acontece nada com ele”.

Professor (a): "Mas se não consigo resolver o problema, peço ajuda da [colegas de trabalho]. Em último caso da direção da escola!’”.

Professor (a): "E às vezes eu também trago os problemas pro [...], pra secretaria ou pra diretoria. Mas porque somo nós, é eu que estou próxi [...] do 
aluno, eu é que conheço [...] a hora que posso pedir para os pais ajudar. A diretoria não sabe como é o dia-a-dia em sala de aula”.

\subsubsection{Apoio entre professores:}

Caracterizou-se pela troca de experiências relativas aos aspectos da organização e condições de trabalho entre os professores, durante a jornada. Forneceram apoio instrumental, como a troca de materiais pedagógicos, substituições e trocas de horários, apoio emocional, como explicitação das dificuldades inerentes à relação professor-aluno-pais-diretoria e apoio informativo, com o esclarecimento de datas relevantes no calendário pedagógico e aspectos burocráticos da instituição.

Professor (a): "Quando alguém tem alguma coisa diferente, a gente sempre passa pros outros".

Professor (a): “Geralmente eu converso com [...] visinh [...] de sala [...], a gente chora as pitangas, reclama um pouquinho ali e depois passa".

Diálogo entre professores (as) sobre as dificuldades de se trabalhar com a indisciplina na sala de aula: "Eles sabem que nada pode acontecer com eles..." afirmou um (a) professor (a), sobre retirar o aluno da sala e enviá-lo para a diretoria. "E falam que nada pode acontecer por causa daquele estatuto da criança... a gente não pode nem argumentar com eles porque eles sabem que têm seus direitos...”completou um (a) outro (a) professor (a). "Então não adianta mais tirar o aluno da 
sala... tem que ser no grito mesmo, aí eles ficam mais acuados..." - reafirmou um (a) terceiro (a) professor (a).

\subsubsection{Apoio dos pais e responsáveis pelos alunos:}

Prática caracterizada pelas respostas dos pais às solicitações e convocações dos professores para discussão sobre a indisciplina dos alunos, dificuldade de aprendizagem e desempenho extra-escolar. A peculiaridade dessa prática reside na expectativa dos professores em contornar a indisciplina por meio da presença dos pais durante o horário de aula, como uma forma de inibir comportamentos agressivos, desinteresse e desatenção, além de procurarem compartilhar, emocionalmente, suas dificuldades inerentes à relação professor-aluno-pais e responsáveis.

Professor (a): “Às vezes, também, a gente chama o pai”.

Porém percebem que isso não soluciona nem os problemas de aprendizagem nem a indisciplina porque os pais não comparecem às convocações.

Professor (a): "Não dá pra fazer mais nada, porque se tenta alguma coisa, os pais não participam e não comparecem nas reuniões".

Diálogo entre professores (as): “E também os pais não ajudam em casa!”exclama um (a). "Já mandei diversos bilhetes, mas não estão nem um pouco 
preocupados." - reafirma o (a) outro (a). "Eles sabem que os filhos não podem ser retidos, por isso nem mesmo se preocupam!” - complementa o (a) primeiro (a).

\subsubsection{Apoio dos alunos:}

Caracterizou-se pela correspondência das expectativas dos professores sobre o processo de aprendizagem e disciplina dos alunos em sala de aula. Esperam um retorno dos alunos sobre seus esforços para ensinar o conteúdo didático, culpando-se por não obter tal retorno. Também esperam desenvolver uma relação social com os alunos de forma a respeitarem e serem respeitados para evitar comportamentos agressivos em sala de aula, procurando a troca afetiva com os mesmos.

Professor (a): "Tem um monte de coisas que a gente pode falar, mas aí eu começo a falar e parece que ta chamando a atenção, que eles não estão ligando... têm três ou quatro olhando e os outros estão brincando conversando”.

Professor (a): "Se eles não prestam a atenção, eu saio devendo. Aí vou pra casa e fico 'aí meu deus, o que é que eu fiz, onde é que eu errei que não consegui passar', não consegui prender a atenção de todo mundo e fiquei devendo”.

Diálogo entre professores (as): “Eu ensinei para eles como fazer, mas não prestam atenção em nada! [...] mas realmente... olha isso! Não sei mais como fazer! Eles não sabem nada!”. 


\section{DISCUSSÃO:}

\subsection{Tipos de apoio:}

\subsubsection{Apoio emocional:}

A expressão e o compartilhamento de conteúdos afetivos, identificados nesta pesquisa, se relacionam com a análise de GIL VILLA (1998) sobre as condições de trabalho dos professores, nas quais está presente o esgotamento diante do acúmulo de exigências, principalmente aquelas relativas ao papel do professor. GREENGLASS e col. (1996) acrescentam ainda o papel do apoio emocional para amenizar a despersonalização no processo de adoecimento pelo esgotamento profissional. Os professores utilizam o apoio emocional como meio de descarga afetiva sobre suas condições de trabalho, bem como aspectos da organização da escola.

O apoio emocional no trabalho se caracterizou, na escola-caso, pelo diálogo e a produção discursiva sobre a relação professor-aluno, que está permeada de representações tais quais "cuidar e educar" e "formar e informar". Alguns professores tendiam a adotar uma postura negativa sobre a educação enquanto processo diferente da transmissão de conhecimento e se sentiam desvalorizados pelos alunos não corresponderem às suas estratégias de educação tradicionais. Segundo CAMPOS (1999), a função do professor de educação básica de "educar e cuidar" se torna grande exigência afetiva no trabalho, contrapondo-se, segundo GONÇALVES (2003), à representação de alguns professores da educação tradicional, sobre seu 
papel de "formar e informar" por meio da transmissão de conhecimento. Essa autora explica que os professores da rede pública se deparam com as necessidades de uma comunidade carente, em que seu papel está além do "formar e informar". Destaca-se que as "professoras, em sua maioria, ressaltam o amor e a afetividade que permeiam sua convivência com os alunos, em especial no que se refere aos mais carentes" (GONÇALVES 2003, p.155). CODO e VASQUES-MENEZES (2000) assinalam que a existência de uma polaridade entre "cuidar e educar" e "formar e informar", denominada de "conflito afeto versus razão", desenvolve um "campo tensional denso" no cotidiano.

Com as exigências afetivas ("cuidar e educar") e o contraste com as concepções de alguns professores sobre a educação como um processo de transmissão de conhecimento ("formar e informar"), o apoio emocional no trabalho desempenha uma função de regular esse tipo de exigência por meio da expressão e compartilhamento da vida afetiva no convívio com alunos.

Por isso, tal apoio se insere na necessidade de compreensão entre a fragmentação cotidiana da relação afetiva (solidariedade, cumplicidade, cuidado, preocupação, desejos, emoções) com os alunos e a "tecnocratização" (método de ensino e organização da transmissão do saber mais adequados e padronizados), conforme assinala SILVA JR (1993). Dessa fragmentação decorrem as excessivas solicitações emocionais dos professores, que refletem na saúde por meio dos quadros de esgotamento, cansaço, desgaste e a síndrome do esgotamento profissional (burnout) (CODO 1999; CODO e VASQUES-MENEZES 2000). 


\subsubsection{Apoio instrumental:}

As trocas de materiais, técnicas pedagógicas e favores técnicos entre os professores se relacionam com precarização do trabalho pela necessidade de suprir a ausência e insatisfação com os materiais pedagógicos fornecidos na tentativa de não inviabilizar o trabalho pedagógico.

GIL VILLA (1998) assinala a falta de recursos materiais como aspecto limitador da atuação profissional, enquanto que CODO e VASQUES-MENEZES (2000) assinalam a precariedade dos recursos materiais de professores da rede de ensino pública. Comparativamente em um outro estudo sobre as representações dos professores acerca do seu trabalho, GONÇALVES (2003, p. 156) identificou que as funções percebidas pelos professores são: "atender a todas as necessidades que surjam como dificuldades ou empecilhos para o desenvolvimento do trabalho na escola, desde questões administrativas às mais práticas, como a manutenção da infraestrutura física". Ainda, GASPARINI e col. (2005) assinalam que a ausência de materiais pedagógicos proporciona o sobre esforço - dedicação extra do professor para a manutenção de mínimas condições de trabalho:

Sob essas condições, o único elemento de ajusto é o trabalhador, que, com seus investimentos pessoais, procura auxiliar o aluno carente comprando material escolar e restringindo seu tempo supostamente livre para criar estratégias pedagógicas que compensam a ausência de laboratórios, de salas de informática e de bibliotecas minimamente estruturadas (GASPARINI e col. 2005, p.191). 
CODO e VASQUES-MENEZES (2000) assinalam que a falta e inadequação de recursos materiais repercute no desgaste psico-fisiológico no trabalho do professor, associando-se a isso o fato de não haver possibilidades de escolha dos materiais mais adequados para suprir as necessidades locais. "Raras são as vezes em que o educador tem ao seu alcance, oferecidos pela instituição, materiais e recursos que vão além desse mínimo, para que possam enriquecer suas aulas, tornando seu trabalho mais interessante, mais eficiente e eficaz" (CODO e VASQUES-MENEZES 2000, p.17).

\subsubsection{Apoio de apreciação:}

A apreciação sobre os resultados do trabalho realizado pelos professores tem importância para a saúde dos professores por três aspectos: (a) prevenção da síndrome do esgotamento profissional, (b) promoção da gestão dos riscos de estresse e (c) expressão afetiva.

Segundo RUSSEL e col. (1987), o retorno positivo sobre o trabalho realizado (feedback positivo) dos professores pode prevenir a síndrome do esgotamento profissional porque facilita o reconhecimento, a compreensão e o manejo do autodesempenho nas tarefas educacionais, facilitando o controle do professor sobre o seu processo de trabalho. Kruger (1997) confirma tal dado ao sugerir que o apoio de apreciação favorece o aumento da auto-eficácia no trabalho com os alunos e na resolução de problemas escolares. 
A eficácia do professor é um conceito que engloba as crenças e convicções da capacidade percebida para modificar o desempenho do aluno no processo de aprendizagem (BROUWERS e TOMIC 2000). SCHWAB e col. (1986), seguidos de BROUWERS e TOMIC (2000), também já assinalaram a importância da percepção da eficácia do professor como um fator de ajuste da condição de trabalho e prevenção do esgotamento profissional. Nesse sentido, BROUWERS e TOMIC (2000) assinalam a influência da falta de eficácia percebida nos sintomas de despersonalização e comprometimento pessoal com o trabalho educacional.

As reuniões de HTPC facilitaram o processo de apreciação sobre o desempenho dos professores da escola-caso estudada. Os professores puderam nortear suas concepções e crenças sobre seu desempenho tanto pelas indicações dadas informalmente, pelos colegas e diretoria, quanto formalmente, por meio das avaliações objetivas realizadas pela diretoria. Segundo a AGÊNCIA EUROPÉIA PARA A SEGURANÇA E A SAÚDE NO TRABALHO (2003), tal tipo de reunião promove a gestão dos riscos de estresse e esgotamento profissional dos professores por, exatamente, favorecer a apreciação sobre seu trabalho. $\mathrm{O}$ autor sugere que as reuniões de avaliação e feedback sobre o trabalho funcionam como um processo de formação contínua porque elas favorecem a análise crítica do desempenho dos professores em relação a competências e domínios técnicos e, muito mais, as possibilidades de solucionar os problemas de práticas que apresentam um desempenho inapropriado, fato corroborado pela pesquisa de SAVOLAINEN (2001). 
A pesquisa realizada pela AGÊNCIA EUROPÉIA PARA A SEGURANÇA E A SAÚDE NO TRABALHO (2003) mostrou que ambientes de trabalho educacionais que favoreçam o apoio de apreciação sobre o trabalho realizado podem: (a) reduzir o número de confrontos físicos entre crianças e professores, (b) diminuir o absenteísmo e (c) aumentar a satisfação dos professores.

Quanto às expectativas da apreciação e retorno de trabalho, referentes ao desempenho dos alunos, CODO e VASQUES-MENEZES (2000) explicam que o envolvimento afetivo do professor e aluno imprime maior qualidade no trabalho educacional. Tal envolvimento, para os autores, permite a expressão afetiva no trabalho, que é regulada pelo espelhamento do professor sobre o desenvolvimento do aluno. Dessa forma, o produto do processo de trabalho educacional é avaliado em termos dos resultados obtidos com o desenvolvimento do aluno. Os autores assinalam que os professores utilizam como parâmetros para a avaliação de resultados a indisciplina e as dificuldades de aprendizagem, percebendo que "nem todos os seus esforços estão produzindo retorno" (CODO e VASQUES-MENEZES 2000, p.41). As conseqüências disso são, para os autores, o desgaste, o questionamento sobre as competências e a fragilização da identidade profissional.

\subsubsection{Apoio informativo:}

GREENGLASS e col. (1996) assinalam os efeitos de amenização da exaustão emocional dos professores por meio do fornecimento de apoio informativo. Nesta pesquisa, as trocas de informações, tanto formais, quanto informais, para a execução 
das tarefas docentes, relacionaram-se com a facilitação e o desenvolvimento de práticas na formação profissional porque promoveram a circulação de conhecimento sobre as atividades docentes na escola-caso. Segundo SILVA (2002, p.80), o cotidiano escolar é "marcado pela constante comunicação formal e informal, espontânea ou intencional (...) e é nesse processo de comunicação que se constroem e reconstroem as ideologias, os valores, os conhecimentos". Os processos comunicacionais que envolvem a troca de informações para o desempenho das tarefas educacionais facilitam ao professor a atualização constate de seus saberes sobre sua prática, promovendo o comprometimento e a qualidade no ensino (SILVA 2002). Para OLIVEIRA DE JESUS (1998), repensar e re-atualizar os saberes sobre as práticas educacionais é um dos meios para se evitar o sentimento de desrealização que pode levar à desistência e ao abandono da profissão, bem como o desenvolvimento e/ou agravamento da síndrome do esgotamento profissional.

Já BARROS (2001) assinala que a troca de informações gerais no trabalho promove a circulação discursiva facilitando a reinvenção de práticas, o que institui um “outro padrão de vida/saúde". Nesse sentido, o apoio informativo aproxima-se do apoio instrumental porque o instrumento de trabalho dos professores se baseia em conteúdos informativos sobre suas práticas, principalmente ao envolver o compartilhamento, entre professores e diretoria, de temas como o processo de aprendizagem, a disciplina dos alunos, métodos de ensino e cursos de capacitação (GALINDO 2004). Torna-se difícil, pois, a análise independente desses dois tipos de apoio pelo fato de se inter-relacionarem, ou seja, as informações adquiridas sobre o 
processo de aprendizagem tornam-se também instrumentos de trabalho à medida de que o produto do trabalho do professorado é imaterial.

\subsection{Fontes de apoio:}

\subsubsection{Apoio da diretoria:}

O apoio da diretoria se mostrou relevante para: (a) o controle das exigências da relação professor-aluno (indisciplina e problemas de aprendizagem), (b) a flexibilização do tempo e ritmo de trabalho (calendário escolar), (c) delimitação dos procedimentos e das regras (planejamento pedagógico) e (d) a avaliação de desempenho (controle da eficiência profissional).

Estudos de BARUCH-FELDMAN e col. (2002); ELFERING e col. (2002); DORMANN e col. (1999); CONSTABLE e RUSSEL (1986) mostram que o apoio social de supervisores, em diversas ocupações, tem efeitos moderadores no estresse ocupacional, no desenvolvimento e/ou agravamento da síndrome do esgotamento profissional e nas dores lombares, além de promover a satisfação e produtividade em diversas categorias profissionais. Para o professorado, tal hipótese também se confirma (GREENGLASS e col. 1998, 1997; BURKE e GREENGLASS 1996,1995; BURKE e col. 1996; SCHWAB e col. 1986; CUNNINGHAM 1983).

SARROS e SARROS (1992) identificaram a importância do apoio social dos diretores como preventivo para o desenvolvimento/agravamento da síndrome do 
esgotamento profissional. Porém, em nenhum desses estudos se constataram as relações com os tipos de ações cotidianas dos diretores que poderiam favorecer o fomento de AST para os professores.

Na escola-caso, as práticas da diretoria se revelaram favoráveis à provisão de apoio social para os professores porque, ao atuarem nos quatro itens acima relacionados, tendem a minimizar alguns aspectos insatisfatórios da organização e condições de trabalho, tais quais levantadas por SOUZA e col. (2003), como: (a) a centralização das decisões administrativas e pedagógicas, (b) o autoritarismo gerencial e (c) a culpabilização pelos resultados negativos do desempenho dos alunos. GONÇALVES (2003) assinala a representação social de professores sobre o papel "positivo" da diretoria é de uma abertura ao diálogo no trabalho em grupo e a administração da escola, repassando normas e diretrizes dos órgãos governamentais.

Além disso, TEIXEIRA (1999) assinala que a diretoria também é responsável pelos tempos e ritmos de trabalho, relacionados com os "transcursos, rotinas, duração, alternâncias, continuidades, sequiências e compassos" das práticas didáticopedagógicas e dos ordenamentos burocráticos determinados e gerenciados pela diretoria. Tais aspectos temporais, segundo a autora, são importantes para o professor porque determinam a "polirritmia escolar", conceito introduzido por TEIXEIRA (1999) para caracterizar as experiências temporais docentes de fragmentação. A polirritmia escolar se constitui em zonas distintas: (a) jornadas triplas, (b) transições entre salas de aulas e diversificação de alunos, (c) transposição entre conteúdos diversos e (d) compatibilização entre o trabalho e vida privada. Para TEIXEIRA 
(1999), a experiência temporal fragmentada é paradoxal porque remete à extensa jornada de trabalho versus o sentimento de um tempo curto. A autora ainda ressalta que tal polirritmia é responsável pela constituição da identidade do professorado. Teixeira assinala que os calendários escolares também estruturam e revelam a rítmica das práticas e atividades docentes, fazendo diferenciação entre o "calendário oficial" determinado pelo MEC e Secretarias de Educação e o "calendário real". O “calendário real”, apesar de se basear no "calendário oficial”, caracteriza-se por um processo de adaptação coletiva à dinâmica e rotinas escolares específicas, os quais são regulados pelas relações de poder e interesses da diretoria. "São uma instância de confronto velado ou aberto entre diretorias, professores, especialistas, estudantes" (TEIXEIRA 1999, p.100).

Por outro lado, a relação social entre professores e diretoria na escola-caso se mostrou ambígua, principalmente porque a provisão do apoio nem sempre foi realizada conforme as necessidades de alguns professores avaliados como profissionais inadequados pela diretoria. Esse fato remete à tese de SILVA JR (1993) de que as escolas públicas foram absorvidas pelo ideário capitalista, em que os professores são considerados trabalhadores improdutivos caso não mostrem um alto índice de "desempenho" e "produtividade". O questionamento do autor é que a subordinação do ensino ao capital desconfigura a proposta da educação, de transformação da sociedade em prol da construção da humanidade. Para o autor, o processo educativo deve basear-se na solidariedade, o que se contrapõe à competitividade capitalista. Percebe-se que a prática de exclusão de professores "menos produtivos" do fornecimento de apoio social pela diretoria reforça tais idéias. 
Além disso, a negativa de provisão de suporte aos professores desconsidera uma das atividades da prática administrativa, que é a regulação das exigências de trabalho e seus efeitos na saúde do trabalhador. Pode-se afirmar que os professores "menos produtivos" são aqueles que têm menos oportunidades de suprirem suas necessidades de apoio social fornecido pela diretoria.

A diretoria exerce, enquanto gerência do processo de trabalho e educador, uma posição ambígua, tal qual identificada nesta pesquisa. A ambigüidade das ações da diretoria é reflexo daquilo que PARO (1996) denominou de "posição bastante contraditória" porque suas funções são, a princípio, inconciliáveis: como educador deve cuidar dos objetivos educacionais e da escola, e como administrador, tem que fazer valer as ordens emanadas dos órgãos públicos superiores do sistema de ensino que, em grande medida, atuam na contrapartida impossibilitando atingir os objetivos educacionais. Dessa forma, justificam-se as dificuldades percebidas pelos professores sobre o fornecimento de apoio por parte da direção, pelo fato da existência de contradições inerentes ao cargo de diretor (a).

Um outro aspecto a ser considerado na relação entre diretoria e a organização do trabalho educacional é a dificuldade de gerenciamento dos próprios recursos, tanto financeiros quanto na escolha do material pedagógico. CODO e VASQUESMENEZES (2000) afirmam que os processos burocráticos das escolas públicas estão submetidos à hierarquização na tomada de decisões, considerando-se que o maior nível hierárquico é o MEC, que estabelece normas, regras, recursos e programas pedagógicos para serem gerenciados pela diretoria das escolas. Os autores ressaltam 
que tal hierarquização (que se perpetua na própria escola com a representação da diretoria responsável pelas decisões internas) repercute na ausência de flexibilidade do trabalho que, associada aos baixos salários, ausências de planos de carreira e infra-estrutura pobre e inadequada, favorecem a insatisfação, falta de sentimentos de realização, baixa auto-estima e desgaste psico-fisiológicos para os professores.

\subsubsection{Apoio entre professores:}

$\mathrm{O}$ apoio entre professores tem sido relatado como significante fator de amenização da exaustão emocional no trabalho docente (GREENGLASS e col. 1996). GALINDO (2004) identificou alguns temas compartilhados entre colegas de trabalho, os quais se assemelham aos temas compartilhados entre os professores da escola-caso: (a) aprendizagem e disciplina dos alunos, (b) métodos de ensino e (c) cursos de capacitação. Já no estudo da escola-caso, o apoio entre os professores se mostrou útil: (a) na regulação das exigências de trabalho tanto no que diz respeito à relação professor-aluno-diretoria-pais (indisciplina, problemas de aprendizagem) com o apoio emocional, (b) na ajuda com o compartilhamento e fornecimento de informações sobre os aspectos temporais do trabalho (calendário escolar) e (c) no compartilhamento e fornecimento de tecnologias educacionais (materiais e procedimentos pedagógicos) e distribuição do trabalho (substituições e trocas de horários).

De forma geral, as relações sociais entre professores são importantes também porque facilitam a construção da identidade de profissional (GALINDO 2004; 
SILVA 2002). Para SILVA (2002) as relações entre pares promovem o sentimento de pertença e de compromisso, que resultam em um trabalho mais significativo. $\mathrm{O}$ autor sugere que é por meio das relações sociais entre pares que o professor aprende a sua profissão, utilizando-se de funções "psicointelectivas" para desenvolver a capacidade de compreender, de trabalhar em grupo, de aprender e ampliar conceitos e novas formas de trabalho. GALINDO (2004) assinala a relevância do reconhecimento entre os professores pares, considerando-se que a vivência da identidade de profissional docente do ensino básico é contraditória, apresentando aspectos positivos, como a formação dos alunos; e negativos, como "criar problemas" para os pais e fazer o aluno "perder o ano letivo". Dessa forma, o apoio social entre professores pode ser entendido como um fator mobilizador de recursos coletivos para a construção de práticas pedagógicas que respondam às exigências do trabalho educacional, formando "informalmente" a identidade profissional do educador. Assinala-se que:

Um grupo permeado de empatia, de responsabilidade mútua, de preocupação com o 'eu' e com o outro, que assegura a participação sem medo de arriscar, de escolher, de se envolver, de compartilhar em direção ao crescimento de todos, mobilizando toda a escola para a conquista de seus objetivos e a satisfação de suas expectativas. (SILVA 2002, p.81).

RAPOSO e MACIEL (2005) assinalam a relevância das relações favoráveis professor-professor para a potencialização dos resultados educacionais e desenvolvimento de trabalhos individuais e coletivos. Os autores localizam tal 
importância nas negociações coletivas entre os professores para a co-construção dos projetos pedagógicos na escola e o aprimoramento da formação profissional. Isso porque os autores entendem que a construção de práticas educacionais surge da reflexão coletiva e partilhada dos professores sobre as tentativas de solucionar os problemas e dilemas pedagógicos e institucionais, o que constitui a "verdadeira formação" profissional do educador. Para tanto, os autores sugerem a análise focal e a promoção de três categorias elementares das relações sociais entre os professores: (a) relação de confiança, (b) interdependência indivíduo-grupo e (c) liderança. Os autores assinalam que:

Nessa perspectiva, a escola deve servir como espaço de trabalho e formação, o que implica gestão democrática e práticas curriculares participativas, que propiciem a constituição de redes de formação contínua [...]. Essa perspectiva valoriza o trabalho do professor como sujeito das transformações que se fazem necessárias na escola e na sociedade e sugere tratamento indissociado entre formação, condições de trabalho, salário, jornada, gestão e currículo (RAPOSO e MACIEL 2005, p.311).

\subsubsection{Apoio dos pais e responsáveis pelos alunos:}

$\mathrm{O}$ apoio recebido dos pais se mostrou relevante para as práticas educativas porque agiu diretamente na regulação dos conflitos existentes nas relações sociais entre professor e aluno. A necessidade de se falar com os pais e trazê-los para a escola é uma prática que os professores usaram para amenizar as exigências 
emocionais e físicas do cuidado com os alunos, compartilhando suas preocupações sobre as condições de vida, relações familiares e desempenho escolar (indisciplina e problemas de aprendizagem). Propuseram aos pais, muitas vezes, o acompanhamento in locus do aluno, tanto na sala de aula quanto no intervalo. Com isso, tentaram distribuir as exigências do trabalho, principalmente quando envolve o papel de “cuidar". E, essa prática foi corroborada pelo estilo de gerência da diretoria, que aprova, coordena e participa para facilitar o trabalho dos professores quanto aos conflitos com os alunos. Mesmo assim, os professores ressaltaram a dificuldade de se fazer útil tal prática, muito em função da ausência dos pais e de sua desvalorização sobre a educação dos filhos.

Essa prática também tenta suprir os sentimentos de desvalorização e pouco reconhecimento profissional (SOUZA e col. 2003) que os professores percebem em relação aos pais e responsáveis. Porém, torna-se muito custosa em termos afetivos porque, segundo GONÇALVES (2003), o constante esforço para trazer os pais para participar do processo educacional resulta em desgaste para os professores. Algumas representações sociais sobre esse tema expressam as expectativas sobre a participação dos pais no processo de educação dos filhos (GONÇALVES 2003). Assinala-se que:

A participação dos pais, por sua vez, é vista como razoável, e há a constatação de que os pais de alunos-problema são ausentes da escola [...]. De maneira geral, há uma sensação de falta de reconhecimento da sociedade e do governo para com a escola e os professores, que se sentem diferenciados (GONÇALVES 2003, p.155). 
"Razoável" acabou sendo um qualificador inexato para a percepção da participação dos pais porque a própria autora ressalta o grande descontentamento dos professores diante da situação. A ausência e falta de participação dos pais é entendida, pelos professores, como acomodação, indiferença e desvalorização da profissão docente e da escola (GONÇALVES 2003). Os pais são, por conseguinte, percebidos como um "fator negativo" para os professores em suas práticas docentes porque não favorecem e/ou facilitam o processo de aprendizagem dos alunos.

\subsubsection{Apoio dos alunos:}

Os professores apresentaram uma expectativa sobre seus alunos, em termos de desempenho, aprendizagem e de comportamentos adequados na escola. Essas expectativas se referiram ao próprio produto final da atividade do professor, que é a educação (CODO e VASQUES-MENEZES, 2000). Com isso, utilizaram os alunos como apoio de apreciação sobre seus desempenhos e apoio para compartilhamento afetivo.

GONÇALVES (2003) assina que as representações de professores sobre o trabalho com os alunos estão baseadas numa convivência de "amor e carinho". CODO e VASQUES-MENEZES (2000) assinalam a necessidade do professor em compartilhar o afeto no processo de ensino-aprendizagem porque tem como produto a educação do aluno e a mudança social, implicando em uma relação social de proximidade e de espelhamento afetivo para o exercício do cuidado. Dessa forma, os 
autores sugerem que o envolvimento no relacionamento permite a expressão afetiva no trabalho, que é regulada pelas relações com os alunos.

PLACCO (2002) reforça a importância da qualidade das relações entre professor e aluno para a construção e transformação "cognitivo-afetivo-social". A autora sugere que as interações e trocas afetivas entre professor e aluno proporcionam transformações e consolidações da identidade do professor e de suas práticas por meio das mudanças nas habilidades, consciência, valores e amplitude do conhecimento.

PEREIRA (1998) sugere que o apoio dos alunos relaciona-se com a satisfação e o sentimento de segurança no trabalho, enquanto que BROUWERS e TOMIC (2000) assinalam sua ausência como relevante para o desenvolvimento e agravamento da síndrome do esgotamento profissional.

Por outro lado, verifica-se a degradação da relação social, em que as necessidades de apoio fornecido pelos alunos são obscurecidas por práticas de ameaças baseadas nas relações autoritárias e abuso de poder nas escolas. ZUIN (2003) ressalta que a relação professor-aluno tem sido permeada pela representação do abuso do poder do professor e conseqüente aversão do aluno, degradando o processo de ensino-aprendizagem. $\mathrm{O}$ autor assinala que é por meio da rotulação, escárnio, humilhação, insultos e punições psicológicas que o professor tenta exercer o controle sobre sua tarefa, para obter a máxima produtividade, objetivando o tempo e os conteúdos pedagógicos. Em contrapartida, o autor assinala que o aluno, além de 
perpetuar seus comportamentos inadequados, também se torna conivente, por meio da dissimulação, com metodologias de ensino inadequadas, na tentativa de evitar ou superar tal abuso de poder do professor.

GIL VILLA (1998) também corrobora com tal possibilidade, analisando a relação professor-aluno nos parâmetros da subordinação institucionalizada, que gera consequiências tanto para uma parte quanto para a outra. Assinala-se que:

A relação, entendida dessa forma, tem sentido tanto para a pessoa que domina - nesse caso, o professor - quanto para o subordinado -os alunos. A diferença é que, quem domina envolve no relacionamento uma parte maior da sua personalidade. [...] É importante ver que a personalidade dominante se esforça não apenas para manter o relacionamento, mas também para lhe atribuir um sentido e, se houver lugar, para aumentar seu significado. Contrariamente, o subordinado tenta conseguir um reordenamento psíquico que diminua o significado do relacionamento até transformá-lo em nada (GIL VILLA 1998).

Os aspectos de dominação e poder/submissão e conformidade caracterizam a relação professor aluno numa dimensão contraditória porque envolve tanto as necessidades de expressão afetiva quanto de controle da tarefa que podem ser ambíguas em suas práticas cotidianas.

O professor espera receber apoio emocional e de apreciação sobre seus esforços, mas, para poder dar conta dos aspectos temporais e das exigências de 
produtividade, controla suas atividades com a construção de uma relação de poder e autoritarismo para com seus alunos, o que gera a retirada do investimento afetivo dos alunos, o conformismo na aprendizagem, indisciplina na sala de aula e a negação da própria relação com o professor. Conseqüentemente, as possibilidades de apoio advindas dessa relação se tornam escassas ou inúteis.

\subsection{Aspectos gerais da estrutura de AST docente:}

AST de professores tem a função de regular as exigências do cotidiano do trabalho educacional. Para tanto, os professores necessitam/utilizam estratégias diversificadas de apoio, tanto em suas fontes quanto em seus tipos, para o manejo de fatores psicossociais adversos relacionados com a precarização das condições e organização do trabalho. THOITS (1995) ressalta a função do apoio social como uma provisão à qual se pode recorrer quando se enfrenta estressores, promovendo a integração social. Diversos autores afirmam que a integração social é relevante para o trabalho docente porque favorece: (a) a construção de identidade profissional e senso de pertença, (b) a formação contínua no ambiente de trabalho, (c) as negociações coletivas sobre projetos pedagógicos, (d) o comprometimento com o processo educacional, (e) a permeabilidade às mudanças na cultura organizacional, (f) o desenvolvimento de funções empáticas, afetivas e relacionais, (g) o desenvolvimento profissional, (h) a construção de novas práticas pedagógicas e (i) a resolução de conflitos e problemas educacionais (RAPOSO e MACIEL 2005; GALINDO 2004; GATTI 2003; SILVA 2002; CODO e VASQUES-MENEZES 2000; OLIVEIRA DE JESUS 1998). Esses aspectos, considerados como 
pertencentes às relações sociais no cotidiano escolar podem favorecer o professorado na tentativa de amenizar o sofrimento relativo às exigências ocupacionais. Sintetizam as possibilidades intervenientes do AST (independentemente de funcionarem como main effect ou buffering) na cadeia de relações psicossociais entre: (1) condições e organização do trabalho, (2) sentidos atribuídos à percepção do ambiente de trabalho e (3) saúde e adoecimento no trabalho.

Desses dados levanta-se a hipótese teórica de uma relação de AST com a formação contínua dos professores. A desqualificação do professor é um imperativo diante da deterioração das condições e organização de trabalho (PARO 1996) e que se faz necessária novas possibilidades de capacitação do professorado. Identificou-se, nesta pesquisa, que as dimensões do apoio social (tipos e fontes) confirmaram a importância das relações sociais no trabalho, as quais têm sido consideradas como co-responsáveis pelo processo de formação desses profissionais (RAPOSO e MACIEL 2005; SILVA 2002; GATTI 2003; OLIVEIRA DE JESUS 1998).

GATTI (2003) reafirma que, para a formação e capacitação, deve-se considerar a dimensão relacional e sócio-afetiva do contexto em que os professores se inserem. A autora assinala que "é necessário que os programas que visam a inovações educacionais, aperfeiçoamentos, atualizações tenham um entrelaçamento concreto com a ambiência psicossocial em que esses profissionais trabalham e vivem" (p.203). 
SAVOLAINEN (2001) sugere que a discussão e colaboração entre os professores podem promover o desenvolvimento da escola e gerar estratégias para a solução de situações problemas no cotidiano educacional, enquanto que RAPOSO e MACIEL (2005) afirmam que a reflexão compartilhada coletivamente favorece a construção e as negociações sobre os projetos pedagógicos, favorecendo assim, a formação do professor. Nesse sentido, JACKSON (1992) ressalta a "experiência compartilhada" e SARASON e col. (1991) assinalam a "percepção da alteridade" como aspectos relevantes para o fornecimento de apoio social. Ou seja, a capacitação do professor, a constituição intersubjetiva de sua identidade enquanto profissional da educação e as possibilidades de reformulação das suas atuações educacionais estão vinculadas com o sentido suportivo construído nas relações sociais de trabalho, por meio do compartilhamento das experiências cotidianas e do reconhecimento da alteridade e, muito além, das possibilidades de trocas afetivas, informativas, instrumentais e de apreciações dos professores com a diretoria, com outros professores, com pais de alunos e responsáveis e com os próprios alunos.

JODELET (1998) assinala que a alteridade é um produto do processo de construção e exclusão social que mantém sua unidade por meio de um sistema de representações. Por isso, para existir compartilhamento, deve haver o reconhecimento do outro num processo de construção coletiva de sentidos sobre o valor suportivo das relações sociais no trabalho docente. Porém, nem todas as relações sociais podem ser consideradas como fomentadoras de um processo de formação profissional entre professores. LANE (1997) utiliza o conceito de “processo grupal” para definir a inserção de sujeitos num modelo produtivo que gera 
materialidade e também auto-reconhecimento enquanto co-autores do próprio processo grupal, ou seja, conscientes das próprias contradições inerentes às relações sociais. Do processo grupal e seus conflitos inerentes, podem surgir o reconhecimento e compartilhamento com a alteridade, inseridos numa atividade produtiva, mas a falta dessa reflexão pode se relacionar com a dissolução do grupo. Para a autora, o questionamento dos papéis sociais assumidos num grupo pode gerar um processo de auto-análise das determinações institucionais que permeiam as relações sociais num grupo, caracterizando assim, a emergência de novos sentidos e o reconhecimento do grupo enquanto grupo e não agrupamento de pessoas num dado espaço e tempo. A categoria "atividade produtiva" - tanto material quanto das relações sociais, é a característica do grupo enquanto grupo e não agrupamento, significando a produção material e a transformação das relações sociais.

Além das relações com a saúde e adoecimento, o apoio social pode ser entendido como um produto das relações grupais entre professores, capaz de facilitar a construção de novas práticas educacionais cotidianas por meio do questionamento e da transformação dos processos institucionais do ensino público. 


\section{CONSIDERAÇÕES E RECOMENDAÇÕES:}

Para a consolidação dos objetivos da pesquisa, realizou-se um levantamento bibliográfico genérico que foi organizado em seis eixos teóricos: (a) organização e condições de trabalho contemporâneo, (b) repercussões do trabalho na saúde dos trabalhadores, (c) fatores psicossociais que delimitam o ambiente de trabalho e suas repercussões na saúde, (d) relevâncias de AST, (e) condições e fatores psicossociais/organização do trabalho docente e (f) AST docente. Esses seis eixos compuseram os capítulos teóricos anteriores da dissertação.

O material preliminar do levantamento bibliográfico sugeriu a importância de AST e, em específico, para o trabalho docente, tanto na prevenção do surgimento ou agravamento de patologias relacionadas, como na promoção da saúde e satisfação dos trabalhadores. Problematizou-se, então, a importância do reconhecimento de AST docente e em seguida, realizou-se um estudo com contribuições da pesquisa qualitativa de estudo de caso descritivo sobre o sentido suportivo atribuído às relações sociais no trabalho de professores da educação básica pública, para se identificar dimensões constitutivas de AST docente, em termos de seu conteúdo tipológico e fontes. Os resultados foram analisados e relacionados com os saberes oriundos de alguns aspectos teóricos delimitados com a teoria das representações sociais, as condições e fatores psicossociais/organização de trabalho e saúde de professores. 
Com esses seis eixos associados à proposta de análise dos dados e os resultados obtidos, pode-se desenvolver uma linha de pensamento por meio de aproximações teóricas interdisciplinares para se compreender as repercussões do apoio social enquanto fator psicossocial relacionado com a mediação da organização e condições do trabalho contemporâneo na saúde dos trabalhadores e, em específico, dos docentes. Ressaltou-se a importância da transição epidemiológica em Saúde Pública, com a relevância das doenças não transmissíveis e dos fatores psicossociais dos padrões de adoecimento coletivos, que também se encontram presentes e relacionados no ambiente de trabalho contemporâneo.

Com base na construção teórico-metodológica acima exposta, as principais contribuições deste estudo foram: (a) proposição de uma definição conceitual de AST fundamentada nas sínteses e reformulações teóricas do levantamento bibliográfico (cf. capítulo 2.1), (b) reformulação do modelo estrutural de AST em termos de quatro categorias, fundamentada no levantamento bibliográfico (cf. capítulo 2.2), (d) delimitação dos alcances dos efeitos de AST na saúde dos trabalhadores e, em especial, dos professores, fundamentada na revisão bibliográfica (cf. capítulos 2.1 e 2.2), (e) identificação e especificação dos tipos e fontes de AST docente, fundamentadas no material coletado (cf. capítulo 6.1, 7.1 e 7.2), (f) explicitação e formulação da função de AST docente, fundamentadas no material coletado e nas discussões dos dados (cf. capítulo 7.3).

Além disso, alguns aspectos críticos também foram considerados. Foram identificadas teorias concorrentes e complementares sobre os fatores psicossociais no 
trabalho (cf. COX e col. 2000; PETER e SIEGRIST 2000; KARASEK e THEORELL 1990) que estão fundamentadas num modelo biologicista, individualista e comportamental-cognitivista (cf. capítulo 1.4). Relacionam AST com o estresse ocupacional e ressaltam a percepção cognitiva dos trabalhadores sobre os estressores, mas não consideram o modo como tais percepções são construídas e compartilhadas coletivamente e historicamente. Assinala-se que esses modelos preservam concepções teóricas e técnicas derivadas de uma epistemologia médico-clínica que está relacionada com um modelo de Saúde Pública clássico, alvo de críticas por exatamente excluir a construção social das dimensões saúde e doença (BEAGLEHOLE e col. 2004). Algumas possibilidades para se responder às necessidades da saúde coletiva são identificadas numa perspectiva de participação coletiva e de parcerias com a população, promovendo a discussão e a construção de práticas promotoras de saúde (BEAGLEHOLE e col. 2004).

A "perspectiva construcionista" da teoria das representações sociais, utilizada nessa pesquisa, favoreceu as análises dos dados coletados na pesquisa porque facilitou a explicitação da construção de um saber e uma prática social relativos ao modus operandis do sentido sobre o fornecimento e das expectativas coletivas sobre o apoio social. Fez-se uma crítica à teoria das representações sociais por, em sua construção mais clássica, priorizar o estruturalismo e o representacionismo. A pesquisa adotou um referencial que se aproxima da construção coletiva de saberes e práticas tal qual é abordada por SPINK (1995, 1996) e ALVES e RABELO (1998) porque não somente respondem às necessidades individuais, mas sim à institucionalização do processo grupal. LANE (1997) assinala que a abordagem 
psicossocial compreende tanto uma microanálise sobre estruturas, relações e contextos grupais quanto uma macroanálise sobre a inserção institucional do grupo e seus processos de internalizações e externalizações nas suas relações com o ambiente, o que torna relevante a compreensão histórica da classe do professorado.

A formação e a construção das práticas educacionais baseiam-se na pluralidade de sentidos construídos e partilhados socialmente, porque "esses profissionais são pessoas integradas a grupos sociais de referência nos quais se gestam concepções de educação, de modos de ser, que se constituem em representações e valores que filtram os conhecimentos que lhes chegam" (GATTI 2003 p.192). Ou seja, o trabalho dos professores tem uma relação com a forma histórica com que foi se constituindo durante o desenvolvimento sócio-cultural brasileiro e como as relações de trabalho dessa classe foram se delineando, conforme explica SOUZA e col. (2003).

BARROS (2001) e PARO (1996) sugerem que as práticas pedagógicas, por serem conseqüência de uma organização de trabalho fundamentada em projetos político-pedagógicos, estão inseridas e se constituem num momento social datado. As representações e práticas coletivas derivadas de um desenvolvimento sóciocultural sugerem o uso associado a uma abordagem sócio-histórica, não somente uma compreensão estática e descritiva dessas práticas tal qual foi proposta e realizada nesta dissertação, devendo-se incluir as condições sócio-culturais e históricas às quais o trabalho dos professores foi e está inserido. Compreender as relações sociais dos professores implica em compreender o modo como a classe foi constituindo-se e 
construindo suas concepções, práticas e representações ao longo do tempo, negociando sentidos coletivos para a delimitação de seu modus operandi cotidiano num curso histórico tanto nos aspectos enquanto classe de trabalhadores como sua inserção na particularidade institucional da escola-caso.

LANE (1997) ressalta que as especificações das relações sociais, ou melhor, do "processo grupal" são elaboradas ao longo do curso histórico da instituição, porque envolve a reprodução de ideologias em decorrência das relações de produção. Portanto, são sugeridas pesquisas que possam associar os projetos políticopedagógicos à estrutura de AST, priorizando a construção sócio-histórica das relações sociais do professorado. Dessa forma poder-se-á compreender, além dos componentes estruturais de AST, as necessidades de fornecimento e recebimento de apoio no trabalho educacional, bem como o processo de negociação de sentido sobre as estruturas das relações suportivas. Sugere-se a compreensão de AST em termos de “processos grupais”, tal qual definido por LANE (1997), utilizando-se de categorias como "contradições" nas relações sociais, "consciência", "transformação social", “atividade produtiva" e "dominação", embutidas no conceito de "processos grupais". Essas categorias podem facilitar o desvelar dos aspectos históricos marcantes das relações sociais no trabalho dos professores. JACOBSON (1986) ressalta tal crítica ao sugerir que se deve compreender AST por meio das dimensões históricas das relações sociais, pois essas são determinantes para sua mobilização no trabalho. $\mathrm{O}$ autor afirma que estudos descritivos sobre apoio social revelam seu aspecto estático e tipológico, mas desconsideram o momento de sua ocorrência, descontextualizando-o do processo de construção das práticas sócio-culturais. 
Por outro lado, esta pesquisa pode identificar e (re) destacar as categorias de "pais e responsáveis pelos alunos" e "alunos" como fontes de AST de professores. Em outro estudo, BURKE e GREENGLASS (1995) assinalaram como fontes importantes para os professores, a diretoria e os pares de trabalho, desconsiderando pais/responsáveis e os próprios alunos. HART (1994) identificou que o comportamento dos estudantes e as exigências das famílias dos alunos podem gerar experiências negativas de trabalho, as quais influem no desenvolvimento do estresse negativo e na queda da qualidade de vida dos professores. Tais categorias, portanto, são relevantes para a compreensão das fontes de apoio no trabalho docente. Torna-se relevante, portanto, o uso dessas categorias na compreensão da estrutura de AST de professores.

Destaca-se, também, que o estudo das relações sociais no trabalho tem sido um aspecto relevante para a compreensão dos mecanismos promotores e/ou agravantes da saúde do trabalhador (APPELBERG 1996). Equipes e grupos de AST têm sido eficientes para a melhoria do clima da equipe (team climate) e da saúde de forma geral (HEANEY e col. 1995). UMIKER (1989) assinalou a importância do desenvolvimento de equipes de AST para: (a) coleta de informações sobre trabalho, (b) aquisição de apoio moral, (c) desenvolvimento profissional e (d) realização das tarefas. Por outro lado, aspectos da organização do trabalho ambíguos e incertos podem influenciar as fontes de apoio social, fomentando a competitividade, a falta de confiança e a negação do fornecimento de apoio específico (ERERA 1992). Sobre tal fato, assinalam-se, por exemplo, as relações ambíguas identificadas entre professores 
e diretoria nesta pesquisa, as quais estão, hipoteticamente, relacionadas com uma concepção de educação capitalista e mercadológica, que exclui os professores “improdutivos" e "inadaptados" ao modelo vigente. Pois, para a fomentação de AST docente, sugere-se a análise da alteridade enquanto conceito que abrange as relações de construção e exclusão e as representações capazes de mediar tal ambigüidade (JODELET 1998).

HART (1994) assinala que experiências positivas e o apoio nas relações sociais de trabalho são fatores relevantes para a promoção da qualidade de vida no trabalho de professores, aumentando a persistência, energia, entusiasmo, coesão e cooperação em grupo. Considerando-se que AST de professores: (a) é um fator de proteção e promoção da saúde, tanto em sua dimensão orgânica quanto psicológica, (b) favorece o desenvolvimento institucional e a qualidade do ensino, (c) favorece a qualificação profissional, (d) promove a integração social, (e) facilita as negociações coletivas e os ajustes na organização do trabalho docente e de projetos pedagógicos e (f) promove a satisfação, o desempenho e o comprometimento com o ensino; sugerese a construção de metodologias e estratégias interventivas na Saúde Pública/Saúde do Trabalhador que privilegiem as relações sociais no trabalho por meio do construto AST de professores e suas dimensões.

BARROS (2001) sugere a construção de "grupos-sujeitos" nas escolas, para a discussão, troca de experiências e a construção de possibilidades do trabalho pedagógico, favorecendo assim a autonomia, a autocrítica e a recriação de práticas docentes. O autor fundamenta-se nas concepções de LANE (1997) sobre a 
constituição do processo grupal enquanto uma atividade de auto-análise e conscientização das contradições decorrentes das relações de poder/dominação e das relações intragrupais para que o grupo, ao produzir algo, se transforme. SAVOLAINEN (2001) também afirma que a discussão nas escolas pode favorecer a solução de situações problemas. Destaca-se a necessidade da promoção de diálogos na construção do conhecimento sobre as práticas educacionais e do reconhecimento do papel do outro na constituição individual e grupal (SILVA 2002). Assinala-se:

\begin{abstract}
Nas instituições educacionais onde os profissionais podem conversar, trocar experiências, falar sobre o seu trabalho, reinventando-o a cada dia, institui-se um outro padrão de vida/saúde, uma vez que a circulação discursiva oxigena as instituições educacionais" (BARROS 2001, p.287).
\end{abstract}

SILVA (2002) refere a um recurso denominado "conselho pedagógico" como um espaço de reuniões entre professores e diretoria para a articulação de estratégias e propostas sobre o processo de ensino-apredizagem. O autor assinala que tal espaço caracteriza-se por encontros coletivos semanais na escola para a discussão de casos concretos sobre o cotidiano escolar. Privilegia-se a comunicação, as trocas e as relações sociais entre professores, diretoria e equipe técnica, favorecendo a reflexão contínua sobre as concepções e práticas docentes. Com isso, segundo o autor, desenvolvem-se competências para o processo educacional porque se articula técnica, conhecimento teórico e relações sociais. UMIKER (1989) assinala que a construção de equipes de AST requer tempo, habilidade, dispêndio de atenção e o desenvolvimento de metas comuns para o aprimoramento da comunicação, 
planejamento, liderança, cooperação, consideração pelo outro, iniciativa, representabilidade e habilidades de negociação no grupo.

Considerando-se tais aspectos, sugere-se, para as escolas de ensino básico estaduais, o uso do HTPC como um espaço para o fomento de grupos de AST. 


\section{REFERÊNCIAS:}

Abramides MBC, Cabral MSR. Regime de acumulação flexível e saúde do trabalhador. São Paulo Perspec. 2003; 17(1): 3-10.

Abric JC. Pratiques sociales et représentations. Paris: Presses Universitaires de France; 1994.

Adams GA, King LA, King DW. Relationships of job and family involvement, family social support, and work-family conflict with job and life satisfaction. J Appl Psychol. 1996; 81(4): 411-20.

Agência Européia para a Segurança e a Saúde no Trabalho. Prevenção de riscos psicossociais no local de trabalho. Luxemburgo: Serviço de Publicações Oficiais das Comunidades Européias; 2003.

Alves PC, Rabelo MC. Repensando os estudos sobre representações e práticas sobre saúde/doença. In: Alves PC, Rabelo MC, organizadores. Antropologia da saúde: traçando identidade e explorando fronteiras. Rio de Janeiro: FioCruz; 1998. p.10721.

Andrea H, Beurskens AJHM, Metsemakers JFM, Van Amelsvoort LGPM, Van Den Brandt PA, Van Schayck CP. Health problems and psychosocial environment as predictors of long term sickness absence in employees who visited the occupational 
physician and/ or general practitioner in relation to work. Occup Environ Med. 2003; 60: $295-300$.

Angrosino MV, Pérez AM. Rethinking observation. In: Denzin NK, Linconl YS, editors. Handbook of qualitative research. $2^{\text {nd }}$ ed. Thousand Oaks: Sage; 2000. p.673702.

Antunes R. Os sentidos do trabalho. $3^{\text {a }}$ ed. São Paulo: Boitempo; 2000.

Appelberg K. interpersonal conflicts at work: impact on health behavior, psychiatric morbidity and work disability. Helsinki: Finnish Institute of Occupational Health; 1996.

Arnetz BB. Causes of change in the health of populations: a biopsychosocial viewpoint. Soc Sci Med. 1996; 43(5): 605-8.

Banco Mundial. Globalização, crescimento e pobreza. São Paulo: Futura; 2003.

Barrera MJr, Ainlay SL. The structure of social support: a conceptual and empirical analysis. J Community Psychol. 1983; 11(2): 133-43.

Barros MEB. A escola, as transformações do mundo do trabalho e o trabalho docente. EM: Borges LH, Moulin MGB, Araújo MD, organizadores. Organização do trabalho e saúde. Vitória: EDUFES; 2001. p.275-94. 
Baruch-Feldman C, Brondolo E, Ben-Dayan D, Schwartz J. Sources of social support and burnout, job satisfaction and productivity. J Occup Health Psychol. 2002; 7(1): 150-93.

Basso IS. Significado e sentido do trabalho docente. Cad CEDES. 1998; 19(44): 1932.

Bauer MW, Gaskell G. Towards a paradigm for research on social representations. J Theory Soc Behav. 1999; 29(2): 163-86.

Bauer MW. Análise de conteúdo clássica. Em: Bauer MW, Gaskell G, organizadores. Pesquisa qualitativa com texto, imagem e som. $2^{\mathrm{a}}$ ed. Petrópolis: Vozes; 2003. p.189-217.

Beaglehole R, Bonita R, Horton R, Adams O, McKee M. Public health in the new era: improving health through collective action. Lancet. 2004; 363: 2084-86.

Beltrán CA, Moreno MP, Reyes MBP. Apoyo social y síndrome de quemarse en el trabajo o burnout: una revisión. Psicología Salud. 2004; 14(1): 79-87.

Benevides-Pereira AMT. Burnout: o processo de adoecer pelo trabalho. Em: Benevides-Pereira AMT, organizadora. Burnout: quando o trabalho ameaça o bemestar do trabalhador. São Paulo: Casa do Psicólogo; 2002. p.21-92. 
Bliese PD, Castro CA. Role clarity, work overload and organizational support: multilevel evidence of the importance of support. Work Stress. 2000; 14(1): 65-73.

Bond MA, Punnett LP, Jean L, Cazeca D, Cooperman M. Gendered Work Conditions, Health, and Work Outcomes. J Occup Health Psychol. 2004; 9(1): 28-45.

Boumans NPG, Landeweerd JA. The role of social support and coping behavior in nursing work. Work Stress. 1992; 6(2): 191-202.

Bourbonnais R, Comeau M, Vezina M. Job strain and evolution of mental health among nurses. J Occup Health Psychol. 1999; 4(2): 95-107.

Bowling NA, Beehr TA, Johnson AL, Semmer NK, Hendricks EA, Webster HA. Explaining potential antecedents of workplace social support: reciprocity or attractiveness? J Occup Health Psychol. 2004; 9(4): 339-50.

Brenner M. Intensive interviewing. In: Brenner M, Brown J, Canter D, editors. The Research Interview. London: Academic Press; 1985. p.147-62.

Brouwers A, Tomic W. a longitudinal study of teacher burnout ans perceived selfefficacy in classroom management. Teach Teacher Educ. 2000; 16:239-53. 
Bültmann U, Kant IJ, Schörer CAP, Kasl SV. The relationship between psychosocial work characteristics and fatigue and psychological distress. Int Arch Occup Environ Health. 2002; 75: 259-66.

Burke RJ, Greenglass ER. A longitudinal study of psychological burnout in teachers. Hum Relat. 1995; 48(2): 187-203.

Burke RJ, Greenglass ER. Work stress, social support, psychological burnout and emotional and physical well being among teachers. Psychol Health Med. 1996; 1(2): 193-205.

Burke RJ, Greenglass ER. Work stress, role conflict, social support, and psychological burnout among teahcers. Psychol Rep. 1993; 73(2): 371-80.

Burke RJ, Greenglass ER, Schwarzer R. Predicting teacher burnout overtime: effects of work stress, social support, and self-doubts on burnout and its consequences. Anxiety Stress Coping Int J. 1996; 9(3): 261-75.

Buunk BP, Doosje BJ, Jans LGJM, Hopstaken LEM. Perceived reciprocity, social support, and stress at work: The role of exchange and communal orientation. J Pers Soc Psychol. 1993; 65(4): 801-11. 
Byrne B. Investigating the impact of background variables of elementary, intermediate, secondary and university educators. Teach Teacher Educ. 1991; 7(2): 197-209.

Campos MM. A formação de professores para crianças de 0 a 10 anos. Educ Soc. 1999; 68: 126-42.

Carlotto MS. Síndrome do burnout e satisfação no trabalho. Em: Benevides-Pereira AMT, organizadora. Burnout: quando o trabalho ameaça o bem-estar do trabalhador. São Paulo: Casa do Psicólogo; 2002. p.187-212.

Carneiro MCBGC. A saúde do trabalhador professor [dissertação]. São Carlos: Univ. de São Carlos; 2001.

Carvalho HTTK. Professora primária. Em: Codo W, Sampaio JJC, organizadores. Sofrimento psíquico nas organizações. Petrópolis: Vozes; 1995. p.127-38.

Castells M. A sociedade em rede. 3ª ed. São Paulo: Paz e Terra: 1999.

Catani PB. Práticas de formação e ofício docente. Em: Bueno BO, Catani DB, Sousa CP, organizadoras. A vida e o ofício dos professores: formação contínua, autobiografia e pesquisa em colaboração. São Paulo: Escrituras; 1998. p.21-9. 
Chan DW, Hui EKP. Stress, support, and psychological symptoms among guidance and non-guidance secondary school teracher in Hong Kong. S Psychol Int. 1998; 19(2): 1969-78.

Chay YW. Social support, individual differences and well-being. J Occup Organ Psychol. 1993; 66: 285-302.

Cheng YC, Walker A. Multifunctions of school-based teacher education. Int J Educ Manag.1997; 11(2): 80-8.

Chisholm RF, Kasl SV, Mueller L. The effects of social support on nuclear worker responses to the Tree Mile Island accident. J Occup Behav. 1986; 7(3): 179-94.

Codo W. Educação: carinho e trabalho. Petrópolis: Vozes; 1999.

Codo W, Vasques-Menezes I. Burnout: sofrimento psíquico dos trabalhadores em educação. São Paulo: INSCUT; 2000.

Cohen S, Gottlieb BH, Underwood LG. Social relationships and health. In: Cohen S, Gottlieb BH, Underwood LG, editors. Social support measurement and intervention: a guide for health and social scientists. New York: Oxford University Press; 2000.

Collins. English mini dictionary. Great Britain: Collins; 1999. 
Collins Gem. Portuguese dictionary. Great Britain: HarperCollings Publishers; 1996.

Conh A, Marsilia RG. Processo e organização do trabalho. Em: Rocha LE, Rigotto RM, Buschinelli, JTP, organizadores. Isto é trabalho de gente? Vida, doença e trabalho no Brasil. Petrópolis: Vozes; 1994. p.56-65.

Constable JF, Russel DW. The effects of social support and the work environment upon burnout among nurses. J Human Stress. 1986; 12(1): 20-6.

Cox T, Griffiths A, Rial-González E. Research on work-related stress. European Agency for Safety and Health at Work: Belgium; 2000.

Creswell JW. Qualitative inquiry and research design. Thousand Oaks: Sage; 1998.

Cruz Neto O. O trabalho de campo como descoberta e criação. Em: Minayo MCS, organizadora. Pesquisa social. $21^{\mathrm{a}}$ ed. Petrópolis; Vozes: 2002. p.51-66.

Cunningham WG. Teacher burnout - solutions for the 80's: a review of the literature. Urban Rev. 1983 15(1): 37-51.

Daniels K, Guppy A. Occupational stress, social support, job control, and psychological well-being. Human Relat. 1994; 47(12): 1523-44. 
Delcor NS, Araújo TM, Reis EJFB, Porto LA, Carvalho FM, Oliveira e Silva M, et al. Condições de trabalho e saúde dos professores da rede particular de ensino de Vitória da Conquista, Bahia, Brasil. Cad Saúde Pública. 2004; 20(1): 187-96.

Denzin NK, Lincoln YS. Introduction: entering the field of qualitative research. In: Denzin NK, Lincoln YS, editors. Handbook of qualitative research. Thousand Oaks: Sage; 1997. p.1-17.

Dollard MF, Winefielf HR, Winefield AH, Jonge J. Psychosocial job strain and productivity in human service workers J Occup Organ Psychol. 2000; 73: 501-10.

Dormann C, Zapf D. Social support, social stressors at work, and depressive symptoms: Testing for main and moderating effects with structural equations in a three-wave longitudinal study. J Appl Psychol. 1999; 84(6): 874-84.

Durand JP. A refundação do trabalho no fluxo tensionado. Tempo Social. 2003; 15(1): $139-58$.

El-Batawi MA. The psychosocial health problems of work in developing countries. In: Kalimo R, El-Batawi MA, Cooper CL, editors. Psychosocial factors at work and their relations to health. Geneva: WHO; 1987. p.15-20.

Elfering A, Semmer NK, Shade V, Grund S, Boos N. Supportive colleague, unsupportive supervisor: the role of provider-specific constellations of social support 
at work in the development of low back pain. J Occup Health Psychol. 2002; 7(2): $130-40$.

Erera IP. Social support under conditions of organizational ambiguity. Human Relat. 1992; 45(3): 247-64.

Esteve JM. O mal-estar docente. Lisboa: Echer/ Fim do Século; 1992.

Evans O, Steptoe A. Social support at work, heart rate and cortisol: a self monitoring study. J Occup Health Psychol. 2001; 6(4): 361-70.

Ferreira ABH. Novo dicionário da língua portuguesa. 2a ${ }^{\text {a }}$ ed. Rev. aum. Rio de Janeiro: Nova Fronteira; 1986.

Fontana A, Frey JH. The interview. In: Denzin NK, Lincoln YS, editors. Handbook of qualitative research. $2^{\text {nd }}$ ed. Thousand Oaks: Sage; 2000. p.645-72.

França Júnior I, Ayres JRCM. Saúde pública e direitos humanos. Em: Fortes PAC, Zoboli ELCP, organizadores. Bioética e saúde pública. São Paulo: Centro Universitário São Camilo/ Loyola; 2003. p.64-9.

Frese M. Social support as moderator of the relationship between work stressors and psychological dysfunctioning: a longitudinal study with objective measures. J Occup Health Psychol. 1999; 4(3): 179-92. 
Friedman R, Kane M, Cornfield DB. Social support and career optimism: examining the effectiveness of network groups among black managers. Human Relat. 1998; 51(9): 1155-77.

Gal M. An investigation of the impact of cronic work stress and critical incidents on correctional staff and the factors that moderate it [dissertation]. Canada: Carleton Univ.; 2004.

Galindo WCM. A construção da identidade profissional docente. Psicologia Ciência Profissão. 2004; 24(2): 14-23.

Gasparini SM, Barreto SM, Assunção AA. O professor, as condições de trabalho e os efeitos sobre a saúde. Educ Pesq. 2005; 31(2): 198-99.

Gatti BA. Formação continuada de professores: a questão psicossocial. Cad Pesq. 2003; 119: 191-204.

Gil Villa F. Crise do professorado. Campinas: Papirus; 1998.

Gonçalves NG. Educação: as falas dos sujeitos sociais. São Paulo: Martins Fontes; 2003. 
Gottlieb NH, McLeroy KR. Social health. In: O'Donnel MP, Harris JS, editors. Health promotion in the workplace. $2^{\text {nd }}$ ed. Albany: Delmar; 1994. p.459-93.

Greenglass ER, Burke RJ, Konarski R. Components of burnout, resources and gender-related differences. J Appl Soc Psychol. 1998; 28(12): 1088-106.

Greenglass ER, Burke RJ, Konarski R. The impact of social support on the development of burnout in teachers. Work Stress. 1997; 11(3): 267-78.

Greenglass ER, Fiskenbaum L, Burke RJ, Schwarzer R, Kleiber D. components of social support, buffering effects and burnout: implications for psychological functioning. Anxiety Stress Coping. 1996; 9(3): 181-275.

Haguette TMF. Metodologias qualitativas na sociologia. Petrópolis: Vozes; 1987.

Heaney CA, Price RH, Rafferty J. Increasing coping resources at work: a field experiment to increase social support, improve work team functioning, and enhance employee mental health. J Organ Behav. 1995; 16(4): 335-53.

Hemström O. Working conditions, the work environment and health. Scand J Public Health. 2001; Suppl 58: 167-84.

Ho JTS. Stress, health and leisure satisfaction: the case of teachers. Int J Educ Manag. 1996; 10(1): 41-8. 
House JS, Umberson D, Landis KR. Structures and processes of social support. Ann Rev Soc. 1988: 14; 293-318.

House JS. Work stress and social support. Massachusetts: Addison-Wesley; 1983.

Hupsey J.E. Social support: assessing conceptual coherence. Qual Health Res. 1998; 8(3): 304-18.

Hutchison C. Social support: factors to consider when designing studies that measure social support. J Adv Nurs. 1999; 29(6): 1520-26.

International Labour Office. Psychosocial factors at work: recognition and control. Geneva: ILO; 1986.

Jackson PB. Specifying the buffering hypotesis. Soc Psychol Q. 1992; 55(4): 363-78.

Jacobson DE. Types and timing of social support. J Health Soc Behav. 1986; 27(3): 250-64.

James K. Workers social identity and health related costs for organizations: a comparative study between ethnic groups. J Occup Health Psychol. 1997; 2(2): 10817. 
Januário AC, Steffani JA, Michels G. Voz: um instrumento humano de trabalho no magistério. RBSO. 2002; 101/102(27): 133-8.

Jodelet D. La representación social: fenomenos, concepto y teoria. En: Moscovici S, organizador. Psicologia social II. Barcelona: Paidós; 1988. p.469-94.

Jodelet D. a alteridade como processo e produto social. Em: Arruda A, organizador. Representando a alteridade. Petrópolis: Vozes; 1998. p.47-67.

Jones RJ. Social identity and relational demography in the workplace: a quantitative investigation of ethnicity, social support and organizational commitment [dissertation]. Washington: The George Washington Univ.; 2005

Jovchelovitch. Vivendo a vida com os outros: intersubjetividade, espaço público e representações sociais. Em: Guareschi P, Jovchelovitch S, organizadores. Textos em representações sociais. $8^{\text {a }}$ ed. Petrópolis: Vozes; 2003. p.63-88.

Judd CM, Smith ER, Kidder LH. Research methods in social relations. $6^{\text {th }}$ ed. Fort Worth: Harcourt Brace Jovanovich; 1991.

Kalimo R. Psychosocial factors and worker's health. In: Kalimo R, El-Batawi MA, Cooper CL, editors. Psychosocial factors at work and their relations to health. Geneva: WHO; 1987. p.3-8. 
Karasek RA, Theorell T. Healthy work: stress, productivity and the reconstruction of working life. New York: Basic Books; 1990.

Karlin WA, Brondolo E, Schartz J. Workplace social support and ambulatory cardiovascular activity in New York city traffic agents. Psychosom Med. 2003; 65: 167-76.

Kaufmann GM, Beehr TA. Occupational stressors, individual strains, and social supports among police officers. Human Relat. 1989; 42(2): 185-97.

Kawakami M, et al. Job strain, social support in the workplace, and haemoglobin A1c in Japanese men. Occup Environ Med. 2000; 57:805-9.

Kortum E. Occupational stress and well-being at work. Afr Newslett Occup Health Safety. 2003; 13: 35-8.

Kruger LJ. Social support and sef-efficacy in problem solving among teachers assistance team and school staff. J Educ Res. 1997; 90(3): 164-8.

Lacaz FAC. Saúde dos trabalhadores: cenários e desafios. Cad Saúde Pública. 1997: 13(2): 7-19. 
Lane STM. Usos e abusos do conceito de representação social. Em: Spink MJ, organizadora. O conhecimento no cotidiano: as representações sociais na perspectiva da psicologia social. São Paulo: Brasiliense; 1995. p.58-72.

Lane STM. O processo grupal. Em: Lane STM, Codo W, organizadores. Psicologia social: o homem em movimento. São Paulo: Brasiliense; 1997. p.78-98.

Langford CPH, Bowsher J, Maloney JP, Lillis PP. Social support: a conceptual analysis. J Adv Nurs. 1997; 25(1): 95-100.

LaRocco JM, House JS, French Jr JRP. Social support, occupational stress and health. J Health Soc Behav. 1980; 21(3): 202-18.

LaRocco JM. Theoretical distinctions between causal and interactional effects of social support. J Health Soc Behav. 1983; 24(1): 91-2.

Levi L. The European Commission's Guidance on work-related stress: from words to action. TUTB Newslett. 2002; 19/20: 12-7.

Lim VKG. Job insecurity and its outcomes: moderating effects of work-based and nonwork-based social support. Human Relat. 1996; 49(2): 171-94.

Lindorff M. Are they lonely at the top? Social relationships and social support among Australian managers. Work Stress. 2001; 15(3): 274-82. 
Liu L. Sensitising concept, themata and shareness: a dialogical perspective of social representations. J Theory Soc Behav. 2004; 34(3): 249-64.

Loscocco KA, Spitze G. working conditions, social support, and well-being of female and male factory workers. J Health Soc Behav. 1990; 31: 313-27.

Lüdke M, André M. Pesquisa em educação: abordagens qualitativas. São Paulo: EPU; 1986.

Mallinckrodt B, Bennett J. Social support and the impact of job loss in dislocated blue collar workers. J Couns Psychol. 1992; 39(4): 482-9.

Maisonneuve J. Introdução à psicossociologia. São Paulo: Edusp; 1977.

Marshall C, Rossman GB. Designing qualitative research. $3^{\text {rd }}$ ed. Thousand Oaks: Sage; 1999.

Martinez MC, Paraguay AIBB, Latorre MRD. Relação entre satisfação com fatores psicossociais e saúde dos trabalhadores. Rev Saúde Pública. 2004; 38(1): 55-61.

McCann BS, Russo J, Benjamin G, Andrew H. Hostility, social support, and perceptions of work. J Occup Health Psychol. 1997; 2(2): 175-85. 
McGrath A, Houghton D, Reid N. Occupational stress and teacher in Northern Ireland. Work Stress. 1989; 3(4): 359-68.

McIntosh NJ. Leader support and responses to work in US nurses. Work Stress. 1990; 4(2): 136-54.

Mendelson MB, Catano VC, Kelloway K. The role of stress and social support in sick building syndrome. Work Stress. 2000; 14(2): 137-55.

Mendes R, Dias EC. Da medicina do trabalho à saúde do trabalhador. Rev Saúde Pública. 1991; 25(5): 341-9.

Minayo MCS. O desafio do conhecimento: pesquisa qualitativa em saúde. $8^{\text {a }}$ ed. São Paulo: Hucitec; 2004.

Ministério da Previdência Social. Estatísticas de acidentes de trabalho. MPS/ DATAPREV; 2003 [citado 2005 out 05]. Disponível em: http://creme.dataprev.gov.br/scripts7/netuno.exe.

Ministério da Saúde. A promoção de saúde no contexto escolar. Rev Saúde Pública. 2002; 36(2): 533-5.

Ministério da Saúde. Doenças relacionadas ao trabalho. Brasília: MS; 2001. 
Ministério do Trabalho e Emprego. Anuário Estatístico de Acidentes do Trabalho 2003. Brasília: MET/ MPAS; 2003.

Moscovici S. A representação social da psicanálise. Rio de Janeiro: Zahar; 1978.

Moscovici S. Representações sociais: investigações em psicologia social. Petrópolis: Vozes; 2003.

Nabi GR. The relationship between HRM, social support and subjective career success among men and woman. In J Manpow. 2001; 22(5): 457-74.

Norbeck JS. Types and sources of social support for managing job stress in critical care nursing. Nurs Res. 1985 Jul-Aug;34(4):225-30.

Nordin M, Knutsson A, Sundbom E, Stegmayr B. Psychosocial factors, gender and sleep. J Occup Health Psychol. 2005; 10(1): 54-63.

Oliver A, Cheyne A, Tomas JM, Cox S. The effects of organizational and individual factors on occupational accidents. J Occup Organ Psychol. 2002; 75(4): 473-89.

Oliveira de Jesus LF. Autoformação: conhecendo a vida e o trabalho de professoras e professores. Em: Bueno BO, Catani DC, Sousa CP, organizadoras. A vida e o ofício dos professores: formação contínua, autobiografia e pesquisa em colaboração. São Paulo: Escrituras; 1998. p.101-10. 
Olstad R, Sexton H, Søgaard AJ. The Finmark study: a prospective study of the social support buffer hypothesis, specific stressors and mental distress. Soc Psychiatry Psychiatric Epidemiol. 2001; 36(12): 582-9.

Organización Internacional de Trabajo. Informe final. II Reunión Paritaria sobre Condiciones de Trabajo del Personal Docente. Genebra: OIT; 1992.

Organización Internacional de Trabajo. Empleo y condiciones de trabajo del personal docente. Genebra: OIT; 1981.

Placco VMNS. Relações interpessoais em sala de aula e desenvolvimento pessoal de aluno e professor. Em: Almeida LR, Placco VMNS, organizadoras. As relações interpessoais na formação de professores. São Paulo: Loyola; 2002. p.7-20.

Paraguay AIBB. Da organização do trabalho e seus impactos sobre a saúde dos trabalhadores. Em: Mendes R, editor. Patologia do Trabalho. $2^{\mathrm{a}}$ ed. São Paulo: Atheneu; 2003. v.1. p.811-23.

Paro VH. A administração escolar: introdução crítica. $7^{\mathrm{a}}$. ed. São Paulo: Cortez; 1996. 
Parkers KR. Coping in stressful episodes: the role of individual diferences, environmental factors, and situational characteristics. J Pers Soc Psychol. 1986; 51(6): 1277-29.

Peter R, Siegrist J. Psychosocial work environment and the risk of coronary heart disease. Int Arch Occup Environ Health. 2000; 73 Suppl.1: S41-5.

Pereira IN. O magistério: um encontro. Em: Bueno BO, Catani DB, Sousa CP, organizadoras. A vida e o ofício dos professores: formação contínua, autobiografia e pesquisa em colaboração. São Paulo: Escrituras; 1998. p.157-60.

Phillips DR, Verhasselt Y. Introduction. In: Phillips DR, Verhasselt Y, editors. Health and development. New York: Routledge; 1994. p.3-32.

Porto LA, Reis IC, Andrade JM, Nascimento CB, Carvalho FM. Doenças ocupacionais em professores atendidos pelo Centro de Estudos em Saúde do Trabalhador (CESAT). Rev Baiana Saúde Públ. 2004; 28(1): 33-49.

Raju PM, Srivastava RC. Factors contributing to commitment to teaching profession. Int J Educ Manag. 1994; 8(5): 7-13.

Raposo M, Maciel DA. As interações professor-professor na co-construção dos projetos pedagógicos na escola. Psic Teor Pesq. 2005; 21(3): 309-17. 
Rau R, Georgiades A, Fredrikson M, Lemne C, Faire U. Psychosocial work characteristics and perceived control in relation to cardiovascular rewind at night. $\mathbf{J}$ Occup Health Psychol. 2001; 6(3): 171-81.

Reinhold HH. Stress ocupacional do professor. Em: Lipp MEN, organizadora. Pesquisas sobre stress no Brasil. Campinas: Papirus; 1996. p.169-94.

Reis EJFB, Carvalho FM, Araújo TM, Porto LA, Silvany Neto AM. Trabalho e distúrbios psíquicos em professores da rede municipal de Vitória da Conquista, Bahia, Brasil. Cad Saúde Pública. 2005; 21(5): 1080-90.

Rhoades L, Eisenberger R. Perceived organizational support: a review of the literature. J Appl Psychol. 2002; 87(4): 698-714.

Rigotto RM. Saúde dos trabalhadores e meio ambiente em tempos de globalização e reestruturação produtiva. RBSO. 1998; 93/94(25): 9-20.

Roy MP, Steptoe A. Daily stressors and social support availability predictors of depressed mood in male firefighters. Work Stress. 1994; 8(3): 210-9.

Russel DW, Altmaier E, Velzen DV. Job-related stress, social support and burnout among classroom teachers. J Appl Psychol. 1987; 72(2): 169-74.

Sá CP. A construção do objeto de pesquisa em representações sociais. Rio de Janeiro: UERJ; 1998. 
Sá CP. Representações sociais. Em: Spink MJ, organizadora. O conhecimento no cotidiano: as representações sociais na perspectiva da psicologia social. São Paulo: Brasiliense; 1995. p.19-45.

Salerno MS. Da rotinização à flexibilização: ensaio sobre o pensamento crítico brasileiro de organização do trabalho. Gestão Produção. 2004; 11(1): 21-32.

Sarason BR, Pierce GR, Shearin EN, Sarason I et al. Perceived social support and working models of self and actual others. J Pers Soc Psychol. 1991; 60(2): 273-287.

Sargent LD, Terry DJ. The moderating role of social support in Karasek's job strain model. Work Stress. 2000; 14(3): 245-61.

Sarros JC, Sarros AM. Social support and teacher burnout. J Educ Adm. 1992; 30(1): s/d.

Savolainen LA. School as worksite: self-assessment of and development needs for working conditions as experienced by students and school personnel [MD Thesis]. Finnland: Tampereen Teknillinen Korkeakoulu; 2001.

Schaubroeck J, Fink LS. Facilitating and inhibiting effects of job control and social support on stress outcomes and role behavior. J Organ Behav. 1998; 19(2): 167-96. 
Schwab RL, Jackson SE, Schuler RS. Educator burnout: sources and consequences. Educ Res Q. 1986; 10(3): 14-30.

Scheafer C, Coyne JC, Lazarus RS. The health-related functions of social support. J Behav Med. 1981; 4(4): 381-406.

Searle B, Bright JEH, Bochner S. Helping people to sort it out: the role of social support in the job strain model. Work Stress. 2001; 15(4): 328-46.

Searle B, Bright JEH, Bochner S. Testing the 3-factor model of occupational stress: the impact of demands, control and social support on a mail sorting task. Work Stress. 1999; 13(3): 268-79.

Seligmann-Silva E. Psicopatologia e saúde mental no trabalho. Em: Mendes R, editor. Patologia do Trabalho. $2^{a}$ ed. São Paulo: Atheneu; 2003. v.2. p. 1141-82.

Siegrist J, Marmot M. Health inequalties and psychosocial environment. Soc Sci Med. 2004; 58: 1463-73.

Silva M. Desenvolvendo as relações interpessoais no trabalho coletivo de professores. Em: Almeida LR, Placco VMNS, organizadores. As relações interpessoais na formação de professores. São Paulo: Edições Loyola; 2002. p. 7990. 
Silva Jr CAS. A escola pública como local de trabalho. $2^{\mathrm{a}}$ ed. São Paulo: Cortez; 1993.

Silvany Neto AM et al. Condições de trabalho e saúde em professores da rede particular de ensino na Bahia: estudo piloto. RBSO. 1998; 91/92(24): 115-24.

Silvany Neto AM, Araújo TM, Dutra FRD, Azi GR, Alves RL, Kavalkievics C, Reis EJFB. Condições de trabalho e saúde dos professores da rede particular de ensino de Salvador, Bahia. Rev Baiana Saúde Publ. 2000; 24(1/2): 42-56.

Siniscalto MT. Statistical profile of the teaching profession. Geneva: ILO; 2002.

Snow DL, Swan SC, Raghavan C, Connell CM, Klein I. The relationship of work stressors, coping and social support to psychological symptoms among female secretarial employees. Work Stress. 2003; 17(3): 241-63.

Sorj B. Sociologia e trabalho. RBSC. 2000; 15(43): 25-34.

Souza KR, Santos MBM, Pina JA, Maria ABV, Carmo MAT, Jensen M. A trajetória do Sindicato Estadual dos Profissionais da Educação do Rio de Janeiro (Sepe-RJ) na luta pela saúde no trabalho. Cienc Saúde Coletiva. 2003; 8(4): 1057-68. 
Souza Filho EA. Análise das representações sociais. Em: Spink MJ, organizadora. O conhecimento no cotidiano: as representações sociais na perspectiva da psicologia social. São Paulo: Brasiliense; 1993. p.109-48.

Spink MJ. Desvendando as teorias implícitas: uma metodologia de análise das representações sociais. Em: Guareschi P, Jovchelovitch S, organizadores. Textos em representações sociais. $8^{\text {a }}$ ed. Petrópolis: Vozes; 2003. p.117-48.

Spink MJP. O conceito de representação social na abordagem psicossocial. Cad Saúde Pública. 1993; 9(3): 300-8.

Stake RE. Case studies. In: Denzin NK, Linconl YS, editors. Handbook of qualitative research. $2^{\text {nd }}$ ed. Thousand Oaks: Sage; 2000. p.435-54.

Steptoe A, Stress, social support and cardiovascular activity over the working day. Int J Psychophysiol. 2000; 37(3): 299-308.

Stiglitz JE. A globalização e seus malefícios. 2a ed. São Paulo: Futura; 2002.

Sylvia RD, Hutchison T. What makes ms. Johnson teach? a study of teacher motivation. Human Relat. 1985; 38(9): 841-56.

Taylor SJ, Bogdan R. Introduction to qualitative research methods: the search for meaning. $2^{\text {nd }}$ ed. New York: John Wiley \& Sons; 1984. 
Teixeira IAC. Cadências escolares, ritmos docentes. Educ Pesq. 1999; 25(2): 87-108.

Tetrick LE, Slack KJ, Silva N, Sinclair RR. A comparision of the stress strain process for business owners and nonowners: differences in job demands, emocional exhaustion, satisfaction, and social support. J Occup Heath Psychol. 2000; 5(4): 46476.

Theorell T, Karasek RA. Current issues relating to psychosocial job strain and cardiovascular disease research. J Occup Health Psychol. 1996; 1(1): 9-26.

Theorell T. Health promotion in the workplace. In: Bandura B, Kickibusch I, editors. Health promotion research: towards a new social epidemiology. Geneva: World Health Organization; 1991. p.251-66.

Theorell T. How will future worklife influence health? Scand J Work Environ Health. 1997; 23(Supp4): 16-22.

Thoits PA. Stress, coping and social support processes: where are we? What next? J Health Soc Behav. 1995; Extra Issue: 53-79.

Tsuboi H, Takeuchi K, Watanabe M, Hori R, Kobayashi F. Psychosocial factors related to low back pain among school in Nagoya, Japan. Ind Health. 2002; 40: 26671. 
Tummers G, Van Merode VM, Landeweerd A, Candel M. Individual-level and group-level relationships between organizational characteristics, work characteristics, and psychological work reactions in nursing work: a multilevel study. Int J Stress Manag. 2003; 10 (2): 111-36.

Uchino BN, Cacioppo JT, Kiecolt-Glaser JK. The relationship between social support and physiological processes: a review with emphasis underlying mechanisms and implications for health. Psychol Bull. 1996; 119(3): 488-531.

Uchino BN, Uno D, Holt-Lunstad J. Social support: physiological processes, and health. Curr Dir Psychol Sci. 1999; 8(5): 141-8.

Umiker W. Develping personal managerial support groups. Health Care Superv. 1989; 7(2): 43-50.

Undén AL. Social support at work and its relationship to absenteeism. Work Stress. 1996; 10(1): 46-61.

Väänänen A, Pahkin K, Kalimo R, Buunk BP. Maintenance of subjective health during a merger: the role of experienced change and pre-merger social support at work in white and blue-collar workers. Soc Sci Med. 2004; 58: 1903-15. 
Väänänen A, Toppinen-Tanner S, Kalimo R, Mutanen P, Vahtera J, Peiro JM. Job characteristics, physical and psychological symptoms, and social support as antecedents of sickness absence among men and women in the private industrial sector. Soc Sci Med. 2003; 57(5): 807-24.

Van-Dick R, Wagner U. Stress and strain in teaching. J Educ Psychol. 2001; 71(2): 243-59.

Vermeulen M, Mustard C. Genbder differences in job strain, social support at work, and psychosocial distress. J Occup Health Psychol. 2000; 5(4): 428-40.

Viswesvaran C, Sanchez JI, Fisher J. The role of social support in the process of work stress: a meta-analysis. J Voc Behav. 1999; 54(2): 314-34.

Vinokur A, Schul Y, Caplan RD. Determinants of perceived social support: interpersonal transactions, personal outlook, and transient affective states. J Pers Soc Psychol. 1987; 53(6): 1137-45.

Wagner W, Duveen G, Farr R, Jovchelovitch S, Lorenzi-Cioldi F, Moarková I, Rose D. Theory and method of social representations. Asian J Soc Psychol. 1999; 2: 95125 .

Waldman EA. A transição epidemiológica. Mundo Saúde 2000; 24(1): 10-8. 
Wood Jr T. Fordismo, toyotismo e volvismo: os caminhos da indústria em busca do tempo perdido. Rev Adm Empresas. 1992; 32(4): 6-18.

Yin RK. Estudo de caso: planejamento e métodos. $2^{\mathrm{a}}$ ed. Porto Alegre: Bookman; 2001.

Youren CG. Stress, coping, and social support experiences of actors working in New York city [dissertation]. Boston: Boston Univ.; 2004.

Zuin AAS. Sobre a atualidade dos tabus com relação aos professores. Educ Soc. 2003; 24(83): 417-27. 


\section{ANEXO 1 - TERMO DE CONSENTIMENTO REFERENTE À ENTREVISTA E OBSERVAÇÃO NO LOCAL TRABALHO - PARA A DIRETORIA:}

Este termo refere-se ao consentimento da direção da escola para a realização da pesquisa, mediante coleta de dados por meio de entrevistas e observações das atividades de trabalho dos professores e devolutiva dos dados.

\section{Sobre a pesquisa:}

Esta pesquisa intitula-se "Relações entre saúde e apoio social no trabalho de professores da educação básica pública" e é a dissertação de Mestrado em Saúde Pública de Rodrigo Manoel Giovanetti, aluno regular do Programa de Pós Graduação da Faculdade de Saúde Pública da USP - Universidade de São Paulo.

A pesquisa tem como conceito principal que o conhecimento dos professores sobre suas relações sociais no trabalho e sua importância para a prevenção de agravos à saúde relacionados ao trabalho e para a promoção da saúde. O método a ser utilizado inclui técnicas de coleta de dados mediante observações do ambiente de trabalho dos professores e entrevistas individuais e coletivas com os mesmos. Essas atividades serão desenvolvidas no período do $2^{\circ}$. semestre de 2005 .

\section{É assegurado a todas as pessoas do local de trabalho:}

- O direto a ser informado sobre os objetivos e resultados do estudo;

- O acesso ao material de anotações e gravações do pesquisador,para os pesquisados;

- A confidencialidade, sigilo e privacidade dos dados, sendo que, na apresentação ou discussão dos resultados, não serão possíveis a identificação de pessoas ou grupos da instituição;

- A possibilidade dos participantes retirarem, a qualquer momento e até o fim da pesquisa, seu consentimento. 
Responsáveis: Rodrigo Manoel Giovanetti (CRP 06/69455) (tel.: 7348-3769), mestrando do Programa de Pós-Graduação da Faculdade de Saúde Pública da USP, Area de Concentração "Saúde Ambiental", sob a orientação da professora doutora Ana Isabel Bruzzi Bezerra Paraguay (tel.: 3066-7115 ramal 232).

$\mathrm{Eu}$

Diretor/Vice-Diretor/ Coordenador da escola XXX, declaro ter sido esclarecido sobre os objetivos, métodos e técnicas da referida pesquisa e consentir que o pesquisador a nessa escola. 


\section{ANEXO 2 - TERMO DE CONSENTIMENTO REFERENTE À ENTREVISTA E OBSERVAÇÃO NO TRABALHO - PARA A DIRETORIA:}

Este termo refere-se ao consentimento individual da diretoria para entrevista e observação no seu ambiente de trabalho, incluindo que sua fala seja gravada, transcrita e analisada, com finalidade de pesquisa acadêmica.

\section{Sobre a pesquisa:}

Esta pesquisa intitula-se "Relações entre saúde e apoio social no trabalho de professores da educação básica pública" e é a dissertação de Mestrado em Saúde Pública de Rodrigo Manoel Giovanetti, aluno regular do Programa de Pós Graduação da Faculdade de Saúde Pública da USP - Universidade de São Paulo.

A pesquisa tem como conceito principal que o conhecimento dos professores sobre suas relações sociais no trabalho e sua importância para a prevenção de agravos à saúde relacionados ao trabalho e para a promoção da saúde. O método a ser utilizado inclui técnicas de coleta de dados mediante observações do ambiente de trabalho dos professores e entrevistas individuais e coletivas com os mesmos. Essas atividades serão desenvolvidas no período do $2^{\circ}$. semestre de 2005.

\section{É assegurado aos participantes:}

- O direto a ser informado sobre os objetivos e resultados do estudo;

- O acesso ao material gravado e possibilidades de censurar partes da gravação, caso deseje;

- A confidencialidade, sigilo e privacidade dos dados, sendo que, na apresentação dos resultados, não serão possíveis a identificação de pessoas ou grupos da instituição;

- A possibilidade dos participantes retirarem, a qualquer momento e até o fim da pesquisa, seu consentimento.

Responsáveis: Rodrigo Manoel Giovanetti (CRP 06/69455) (tel.: 7348-3769), mestrando do Programa de Pós-Graduação da Faculdade de Saúde Pública da USP, Area de 
Concentração "Saúde Ambiental", sob a orientação da professora doutora Ana Isabel Bruzzi Bezerra Paraguay (tel.: 3066-7115 ramal 232).

$\mathrm{Eu}$

Diretor/ Coordenador da escola XXX, declaro ter sido esclarecido sobre os objetivos, métodos e técnicas da referida pesquisa e consentir que o pesquisador a nessa escola. 


\section{ANEXO 3 - TERMO DE CONSENTIMENTO REFERENTE À ENTREVISTA E OBSERVAÇÃO NO TRABALHO - PARA OS PROFESSORES:}

Este termo refere-se ao consentimento individual do professor para entrevista e observação no seu ambiente de trabalho, incluindo que sua fala seja gravada, transcrita e analisada, com finalidade de pesquisa acadêmica.

\section{Sobre a pesquisa:}

Esta pesquisa intitula-se "Relações entre saúde e apoio social no trabalho de professores da educação básica pública" e é a dissertação de Mestrado em Saúde Pública de Rodrigo Manoel Giovanetti, aluno regular do Programa de Pós Graduação da Faculdade de Saúde Pública da USP - Universidade de São Paulo.

A pesquisa tem como conceito principal que o conhecimento dos professores sobre suas relações sociais no trabalho e sua importância para a prevenção de agravos à saúde relacionados ao trabalho e para a promoção da saúde. O método a ser utilizado inclui técnicas de coleta de dados mediante observações do ambiente de trabalho dos professores e entrevistas individuais e coletivas com os mesmos. Essas atividades serão desenvolvidas no período do $2^{\circ}$. semestre de 2005 .

\section{É assegurado aos participantes:}

- O direto a ser informado sobre os objetivos e resultados do estudo;

- O acesso ao material gravado e possibilidades de censurar partes da gravação, caso deseje;

- A confidencialidade, sigilo e privacidade dos dados, sendo que, na apresentação dos resultados, não serão possíveis a identificação de pessoas ou grupos da instituição;

- A possibilidade dos participantes retirarem, a qualquer momento e até o fim da pesquisa, seu consentimento.

Responsáveis: Rodrigo Manoel Giovanetti (CRP 06/69455) (tel.: 7348-3769), mestrando do Programa de Pós-Graduação da Faculdade de Saúde Pública da USP, Area de 
Concentração "Saúde Ambiental", sob a orientação da professora doutora Ana Isabel Bruzzi Bezerra Paraguay (tel.: 3066-7115 ramal 232).

$\mathrm{Eu}$

_ , professor(a) da escola XXX, declaro ter sido esclarecido sobre os objetivos, métodos e técnicas da referida pesquisa e consentir que o pesquisador a nessa escola 
ANEXO 4 - GUIA DE ENTREVISTA EM PROFUNDIDADE:

\section{DADOS GERAIS}

- Sexo;

- Idade;

- Tempo de trabalho na escola;

\section{APOIO SOCIAL NO TRABALHO}

- Questão norteadora: "gostaria que você comentasse sobre seu trabalho";

- Como percebe os tipos de apoio social: apoio material, informacional, emocional, de avaliação e feedback; Como os descreve em sua prática;

- Como percebe as fontes de apoio social no trabalho: dos colegas de trabalho, da direção, outros; Como atribui o caráter de apoio para essas fontes;

- Quais são os indicadores que percebe como constituintes de apoio social no trabalho; Como os qualifica em sua prática.

- Como percebe a influência e repercussões das relações sociais de apoio no trabalho com a saúde; Identifica alguma repercussão das relações sociais na saúde; Como ocorre. 


\section{ANEXO 5 - GUIA DE DIÁRIO DE CAMPO - ADAPTADO DE LÜDKE E ANDRÉ (1986):}

\section{DESCRIÇÃO DOS SUJEITOS}

Aparência física; maneirismos; modos de falar e agir com outros sujeitos no trabalho.

\section{RECONSTRUÇÃO DOS DIÁLOGOS}

Palavras, gestos, depoimentos e falas com outros sujeitos no trabalho e com o pesquisador.

\section{DESCRIÇÃO DOS LOCAIS}

Ambiente onde foi feita a observação (sala de aula, sala dos professores, sala de reuniões, pátio, etc.) - espaço físico.

\section{DESCRIÇÃO DE EVENTOS ESPECIAIS}

Reuniões entre professores e pais, professores e direção. Acontecimentos diferenciados da rotina escolar (indisciplina e reações dos professores para com pais e alunos, eventos significativos para os professores, etc.).

\section{DESCRIÇ̃̃O DAS ATIVIDADES}

Relações sociais entre professores, professores e alunos, professores e direção, professores e pais de alunos.

\section{COMPORTAMENTO DO PESQUISADOR}

Atitudes, ações e conversas com os participantes da pesquisa. 
